\title{
ANALYSING SMALLHOLDER FARMERS' ADOPTION OF NEW TECHNOLOGY UNDER THE CONSIDERATION OF RISK ATTITUDES AND TIME PREFERENCES
}

\author{
Dissertation \\ to attain the doctoral degree (Dr. rer. pol) \\ of the Faculty of Agricultural Sciences \\ University of Göttingen, Germany
}

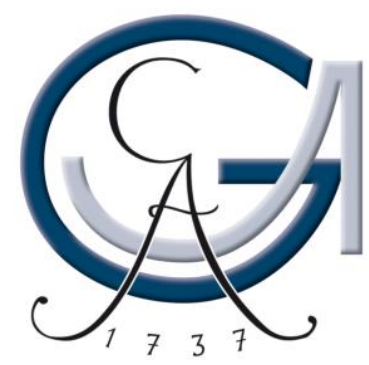

Submitted by:

Arieska Wening Sarwosri

Born on $28^{\text {th }}$ March 1988 in Surakarta, Indonesia

Göttingen, December 7th 2020 
$1^{\text {st }}$ Referee: Prof. Dr. Oliver Mußhoff

$2^{\text {nd }}$ Referee: Prof. Dr. Matin Qaim

$3^{\text {rd }}$ Referee: Prof. Dr. Jann Lay

Date of oral examination: $7^{\text {th }}$ December 2020 


\section{SUMMARY}

Technology adoption in agriculture plays a vital role in coping with exponential population growth. Since the Green Revolution in the 1960s, researchers have been extensively investigating issues and challenges in technology adoption. These issues are more complex in developing countries due to poverty and shortcomings in agricultural insurances. Poor farmers who are risk-averse and favor a higher discount rate tend to opt-out from adopting the innovations, causing poverty-traps. Emerging attention on environmental degradation from customers in more developed countries also gives pressure to farmers for practicing sustainable farming, especially when they grow controversial crops such as oil palm.

High productivity and low production cost in comparison to other vegetable oils have led to palm oil dominating the world market. In one hand, the palm oil production increases farmers' welfare and improves their nutrition intake. In the other hand, palm oil production threatens biodiversity and promotes deforestation. However, achieving farmers' adoption of sustainable farming practices also meets challenges due to lack of awareness and information for environmental conservation.

This dissertation proposes a topic of technology adoption under the consideration of risk attitudes and time preferences. The study was conducted in Jambi Province, Sumatra, Indonesia. We involved smallholder farmers (in later parts, we refer to them as "farmers"), who cultivated oil palm, rubber, and both. This dissertation consists of three papers covering: (1) farmers' adoption of palm oil certification that indicates sustainable palm oil production; (2) farmers' adoption of a new type of crops; (3) farmers' risk attitude and time preferences, where we broaden our observations by involving farmers from another comparable developing country, namely India.

The first paper investigates three policy scenarios to support farmers' participation in palm oil certification. The certification programs were introduced to mediate the trade-offs between the economic benefits and environmental consequences of oil palm cultivation, for example, deforestation. However, farmers' participation rates remain low, even though the certification programs have been introduced since many years. Regarding the escalating concern for environment, effective policies to increase farmers participation in the certification programs are needed. To evaluate the effect of the policy scenarios, we utilized a social dilemma experiment. We found that price premiums for certified palm oil and information about landuse change motivate farmers to conserve the forest. 
The second paper discusses oil palm adoption by farmers, which happened relatively fast, contradicting the literature that mentions farmers' slow adoption. In Jambi, rubber was an important crop cultivated among generations. The farmers cultivate rubber in both agroforest and monoculture form, where the monoculture gives higher profits than agroforest. Meanwhile, farmers' oil palm cultivation was initiated later, coupled with the transmigration program around the year 1900. In this program, the farmers received supports from the government for early establishment of oil palm plantations. When the program and the support were gradually reduced, farmers continued the adoption independently.

Previous literature mentions that higher profit per head of labour working in oil palm plantations and the possibility to add income from off farm activities are some reasons of the farmers' fast adoption. However, if farmers only seek for higher profits than what they already received from agroforest, converting part of the agroforest to a rubber monoculture should be a safer choice than establishing oil palm plantations. Rubber has been cultivated longer. Hence, the farmers have prior knowledge of rubber cultivation. Moreover, rubber monoculture has higher returns per hectare than oil palms. Thus, it seems that the adoption also reasoned by an intention to cultivate two crops. We analyze this crop adoption with the underlying hypothesis that farmers' risk attitudes and time preferences affect crop-diversification. Our findings show that risk-averse farmers prefer to cultivate both crops.

Prior knowledge about the direction and strength of farmers' risk attitudes and discount rates is important in technology adoption. The policymaker can use this knowledge to plan informed future policies supporting technology adoption. Risk aversion and high discount rates inhibit farmers from participating in innovations and trap them in poverty. The third paper presents the risk attitudes and time preferences of farmers from India and Indonesia and compares them. Our finding shows that Indian farmers have a higher level of risk aversion compared to Indonesian farmers, but farmers from both countries show extremely high discount rates compared to results from studies in other countries. 


\section{ZUSAMMENFASSUNG}

Die Nutzung neuer Technologien in der Landwirtschaft spielt eine entscheidende Rolle, um die durch exponentielles Bevölkerungswachstum bedingten Herausforderungen zu bewältigen. Seit der Grünen Revolution der 1960er Jahre haben Forscher Probleme und Herausforderungen, welche mit der Nutzung von neuen Technologien verbunden sind, eingehend untersucht. Diese Probleme sind in Entwicklungsländern aufgrund von Armut und mangelhaften landwirtschaftlichen Versicherungen noch komplexer. Landwirte mit niedrigem Einkommen, die risikoavers sind und eine hohe Diskontrate bevorzugen, nutzen selten innovative Technologien, wodurch sie in Armut gefangen bleiben. Eine erhöhte Aufmerksamkeit gilt in weiter entwickelten Ländern auch der Umweltzerstörung durch landwirtschaftliche Aktivitäten. Dementsprechend werden Landwirte als Produzenten unter Druck gesetzt, nachhaltige Landwirtschaft zu betreiben, besonders wenn sie umstrittene Nutzpflanzen wie Ölpalmen anbauen. Hohe Produktivität und niedrige Produktionskosten im Vergleich $\mathrm{zu}$ anderen Pflanzenölen haben dazu geführt, dass Palmöl den Weltmarkt dominiert. Einerseits erhöht die Palmölproduktion das Einkommen der Landwirte und verbessert ihre Ernährungssituation. Auf der anderen Seite bedroht sie Biodiversität und fördert die Abholzung des Regenwaldes. Mangelndes Bewusstsein für den Umweltschutz und mangelnde Informationen über dieses Thema stellen eine weitere Herausforderung dar.

Diese Dissertation analysiert die Nutzung neuer Technologien unter Berücksichtigung von Risikoeinstellungen und Zeitpräferenzen. Die der Dissertation zu Grunde liegenden Studien wurden in Jambi durchgeführt, einer Provinz auf der indonesischen Insel Sumatra. Der Fokus liegt auf Kleinbauern, die Ölpalmen und/oder Kautschuk anbauen. Die Dissertation besteht aus drei Kapiteln, die folgende Themen behandeln: (1) Die Teilnahme von Landwirten an Palmölzertifizierung, was eine nachhaltige Produktion von Palmöl bedeutet; (2) Die Kultivierung neuer Nutzpflanzen durch Landwirte; (3) Die Risikoeinstellungen und Zeitpräferenzen von Landwirten, wofür wir Daten von Landwirten aus einem vergleichbaren Entwicklungsland, nämlich Indien, mit einbeziehen.

Das erste Kapitel untersucht drei Politikszenarien, die die Teilnahme der Landwirte an Zertifizierungsprogrammen für Palmöl fördern sollen. Die Palmölzertifizierungsprogramme wurden eingeführt, um die Konflikte zwischen ökonomischen Vorteilen für Landwirte und negativen Umweltfolgen des Ölpalmenanbaus zu mindern, zum Beispiel die Abholzung von Regenwald. Bisher zeigen die Landwirte jedoch eine niedrige Beteiligung, obwohl die 
Zertifizierungsprogramme seit vielen Jahren existieren. In Anbetracht der wachsenden Besorgnis über die Umweltfolgen sind wirksame Interventionen erforderlich, um die Beteiligung der Landwirte an den Zertifizierungsprogrammen zu erhöhen. Um den Effekt der Politikszenarien zu evaluieren, haben wir ein soziales Dilemma-Experiment implementiert. Unsere Ergebnisse zeigen, dass Preisaufschläge für zertifiziertes Palmöl und Informationen über Landnutzungsänderungen die Landwirte motivieren, den Wald zu erhalten.

Das zweite Kapitel diskutiert die rasche Übernahme von Ölpalmenanbau durch die Landwirte, die der in der Literatur beschriebenen langsamen Übernahme neuer Technologien widerspricht. In Jambi ist Kautschuk seit vielen Generationen ein wichtiges Anbauprodukt. Die Landwirte bauen den Kautschuk sowohl in Agroforsten als auch in Monokultur an, wobei die Monokultur höhere Gewinne abwirft als der Agroforst. Demgegenüber wurde der Ölpalmenanbau später von der Regierung in Verbindung mit dem so genannten Transmigrationsprogramm um das Jahr 1900 initiiert. In diesem Programm erhielten die Landwirte Unterstützung von der Regierung für die erste Errichtung von Ölpalmenplantagen. Nach der Reduktion des Programms und der Unterstützung setzten die Landwirte die Einführung von Ölpalmen selbstständig fort.

In der Literatur wird beschrieben, dass ein höherer Gewinn pro Kopf bei Ölpalmenplantagen und die Möglichkeit, das Einkommen durch außerlandwirtschaftliche Tätigkeiten zu erhöhen, einige Gründe für die schnelle Akzeptanz der Landwirte sind. Wenn sie jedoch nur höhere Profite anstreben als die, die sie mit den bisherigen Kautschuk-Agroforsten erzielen, sollte die teilweise Umwandlung in eine Kautschuk-Monokultur eine sicherere Wahl sein als die Umwandlung in Palmölplantagen. Kautschuk wird schon länger angebaut, und daher haben die Landwirte mehr Vorkenntnisse in dessen Anbau. Darüber hinaus hat die KautschukMonokultur höhere Erträge pro Hektar als Ölpalmen. Es scheint also, dass die Akzeptanz auch durch die Absicht begründet ist, zwei Nutzpflanzen anzubauen. Wir analysieren die Wahl der Anbaukultur auf Grundlage der Hypothese, dass die Risikoeinstellungen und die Zeitpräferenzen der Landwirte die Diversifizierung des Anbaus beeinflussen. Unsere Ergebnisse zeigen, dass risikoaverse Landwirte es vorziehen, beide Nutzpflanzen anzubauen.

Kenntnisse über die Richtung und Ausprägung von Risikoeinstellungen und Zeitpräferenzen der Landwirte sind wichtig für die Einführung neuer Technologien. Politische Entscheidungsträger können dieses Wissen nutzen, um fundierte künftige Maßnahmen zur Unterstützung der Technologieübernahme zu planen. Risikoaversion und hohe Diskontraten hindern Landwirte, innovative Technologien anzuwenden und halten sie in Armut gefangen. 
Das dritte Kapitel analysiert die Risikoeinstellungen und Zeitpräferenzen von Landwirten in Indonesien und Indien und vergleicht sie. Unsere Ergebnisse zeigen, dass indische Landwirte im Vergleich zu indonesischen Landwirten eine höhere Risikoaversion haben, jedoch sind Landwirte aus beiden Ländern sehr risikoavers im Vergleich zu Studienergebnissen in anderen Ländern. 


\section{CONTENTS}

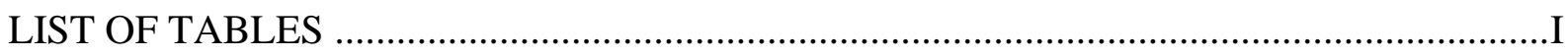

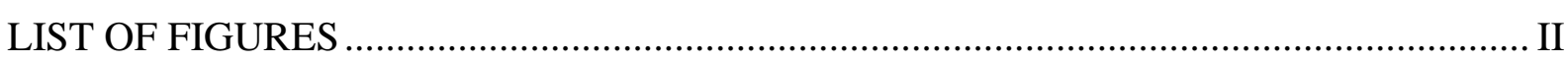

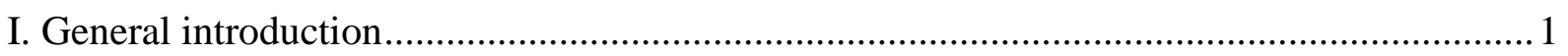

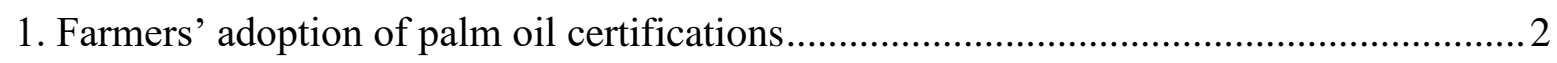

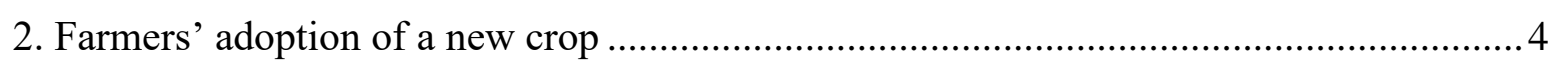

3. Farmers' risk attitudes and time preferences ................................................................

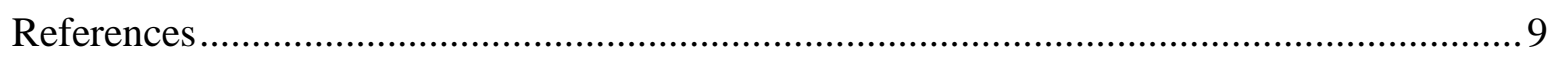

II. Discouraging rainforest transformation: an ex-ante policy impact analysis........................ 13

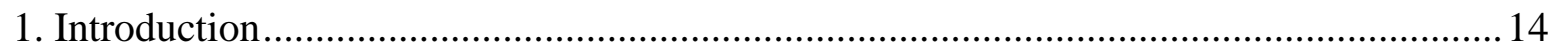

2. Conceptual framework and derivation of hypotheses...................................................... 16

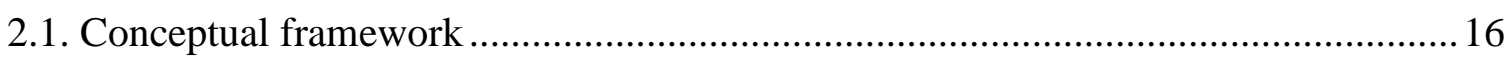

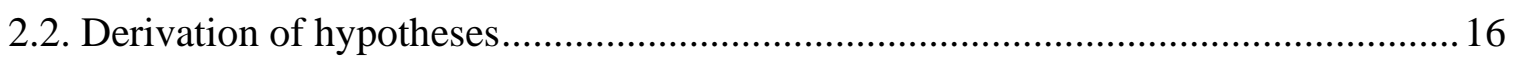

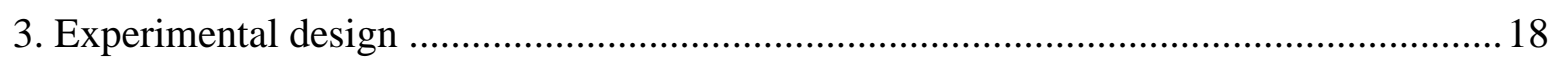

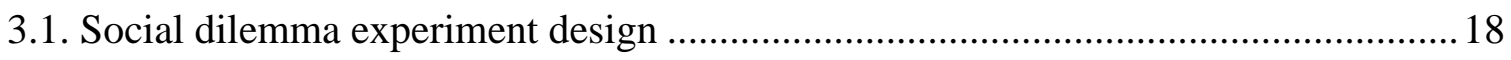

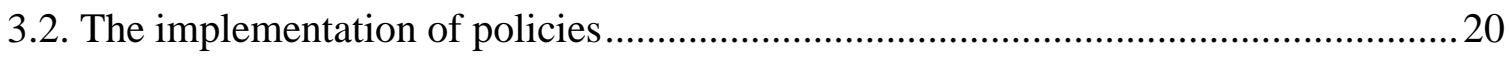

3.3. Study region, sample selection and descriptive statistics...........................................21

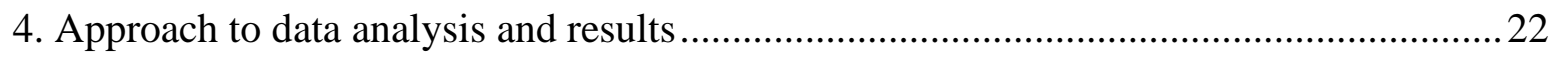

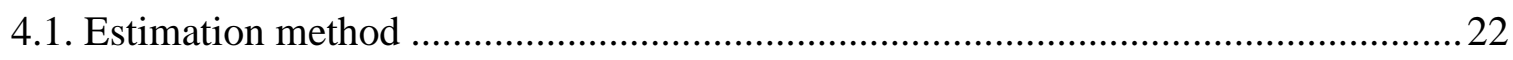

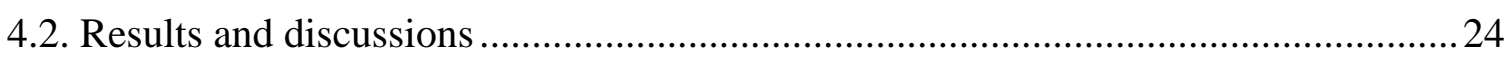

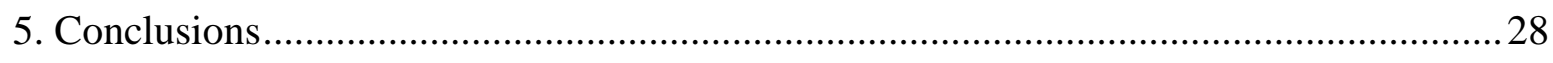

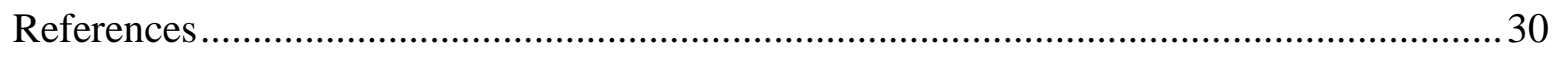

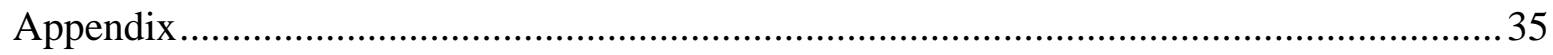

III. Are risk attitudes and time preferences crucial factors for crop-diversification by

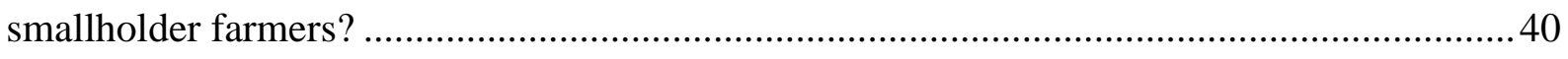

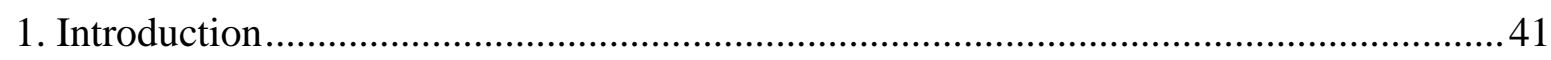

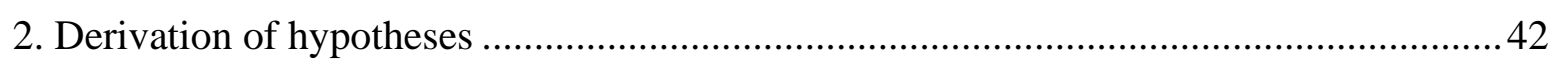

2.1. Risk attitudes of the farmers and crop choice ............................................................4 42

2.2. Time preferences of the farmers and crop choice ………………………………......4 44

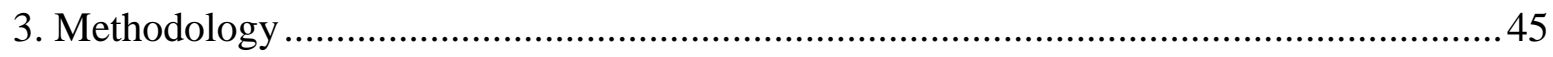

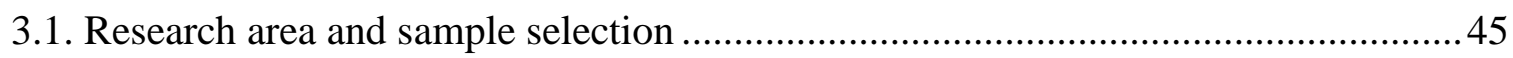

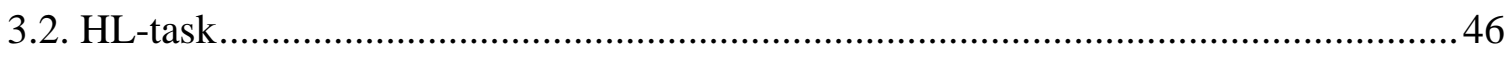


3.3. CW-task

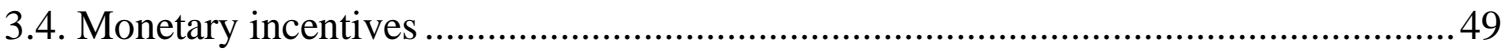

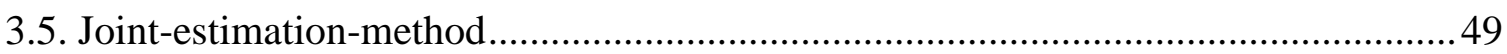

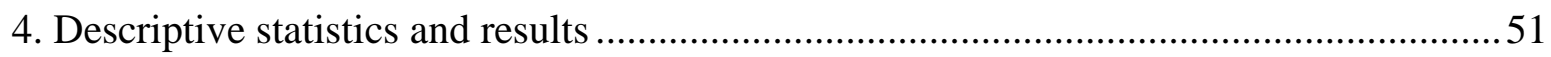

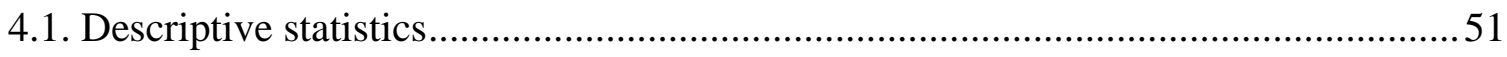

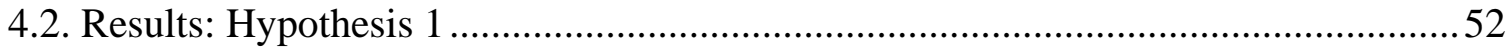

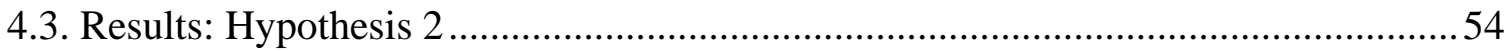

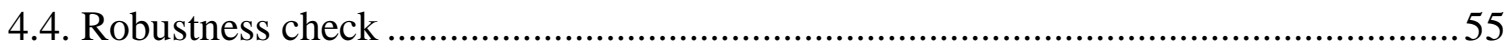

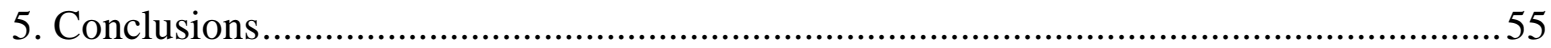

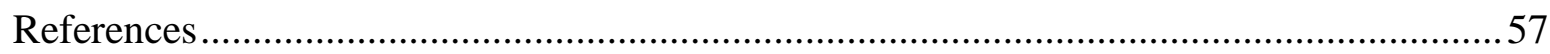

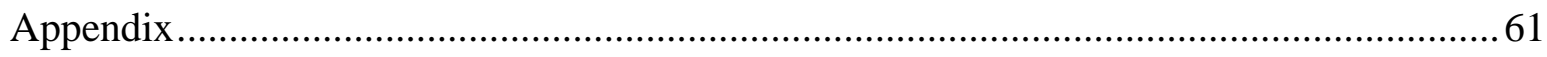

IV. Risk attitudes and time preferences of smallholder farmers in two comparable Asian

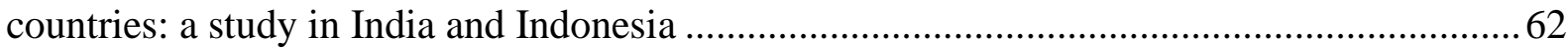

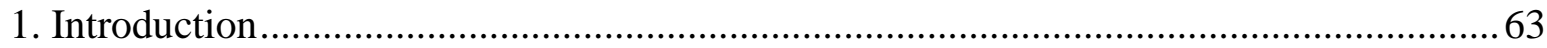

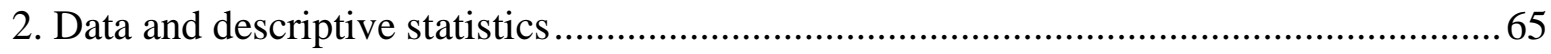

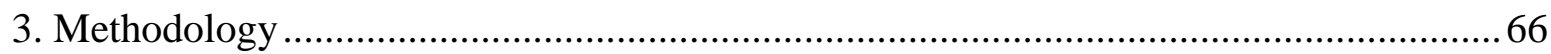

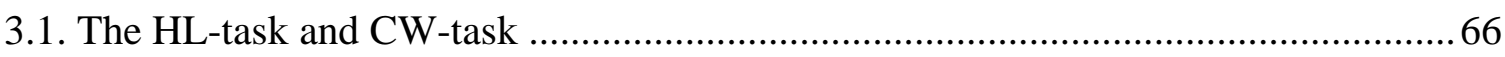

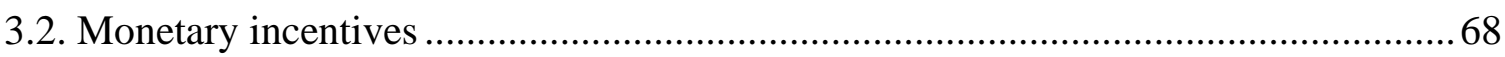

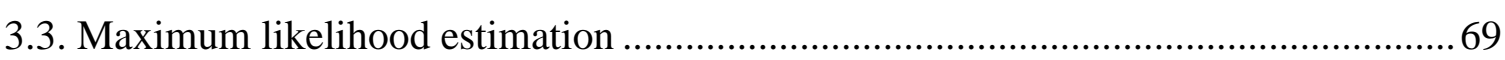

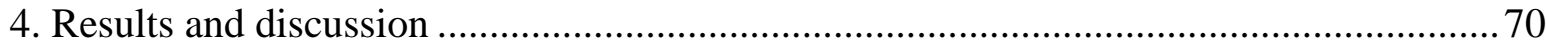

4.1. Comparison of farmers' preferences in India and Indonesia ................................. 71

4.2. Robustness check and possible influencing factors of the sociodemographics ......... 72

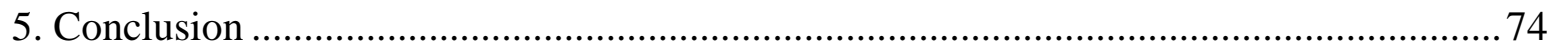

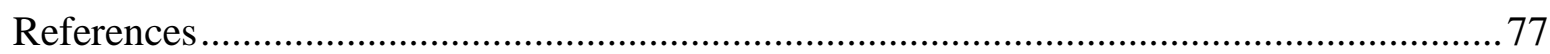

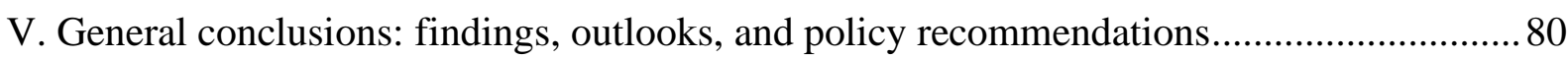

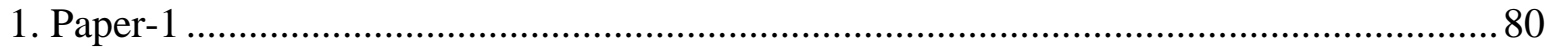

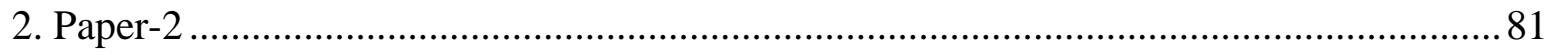

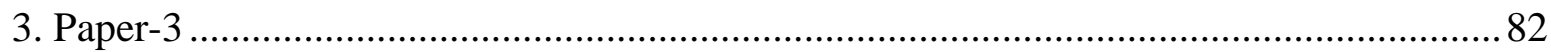

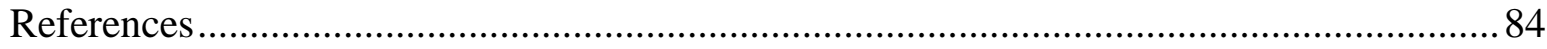

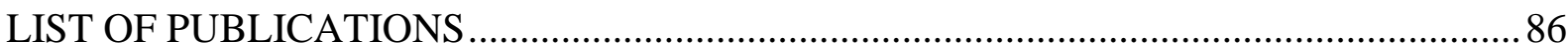

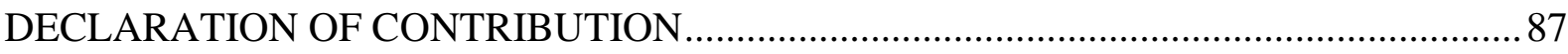

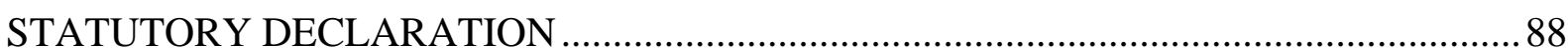




\section{LIST OF TABLES}

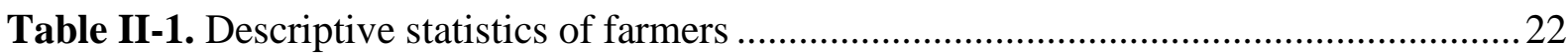

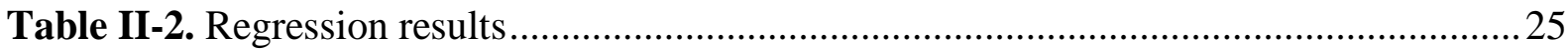

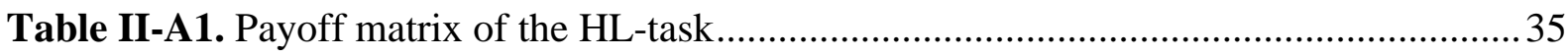

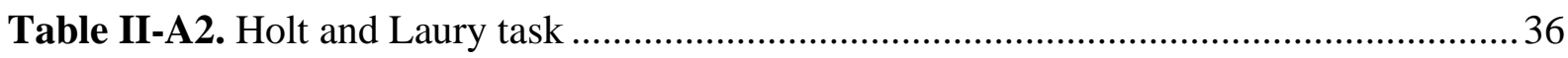

Table III-1. Multiple price list of the HL-task of rubber and double-crop farmers ...............47

Table III-2. Payoff matrix of the CW- task of rubber and double-crop farmers .................... 48

Table III-3. Descriptive statistics of rubber and double-crop farmers ................................52

Table III-4. Risk aversion coefficients and discount rates of farmers .................................53

Table III-5. Model estimates of risk attitudes and time preferences with farmers'

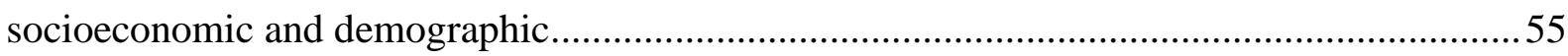

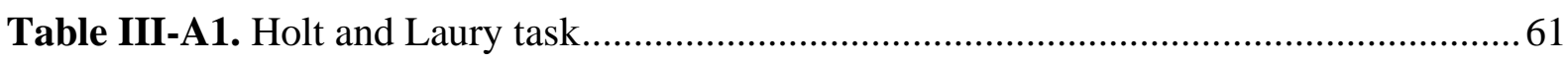

Table III-A2. Correlation coefficients for farmers' socioeconomic and demographic variables

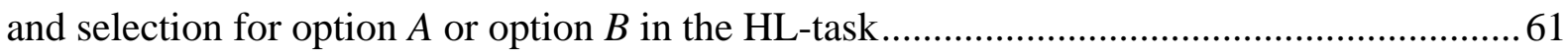

Table IV-1. Descriptive statistics of Indian and Indonesian farmers .....................................66

Table IV-2. Multiple price list of the HL-task of Indian and Indonesian farmers..................67

Table IV-3. Payoff matrix of the CW-task of Indian and Indonesian farmers ........................68

Table IV-4. Maximum likelihood estimation results of farmers' risk aversion and time preferences in India and Indonesia 


\section{LIST OF FIGURES}

Figure I-1. World production of palm oil ...................................................................

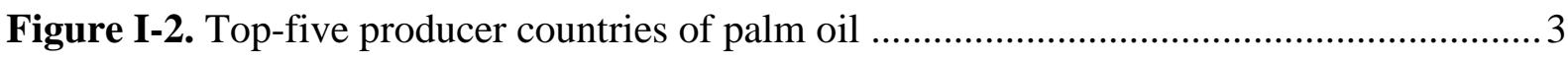

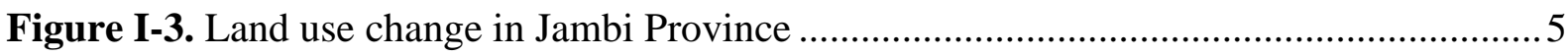

Figure II-1. Oil palm expansion over experiment rounds ..............................................2 23

Figure II-2. Distribution of oil palm expansion in the social dilemma experiment ...............24

Figure II-A1. The page of the questionnaire for the social dilemma experiment ...................37

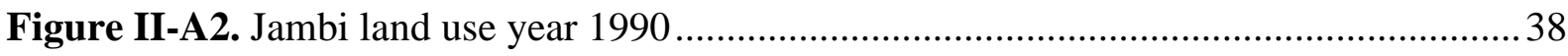

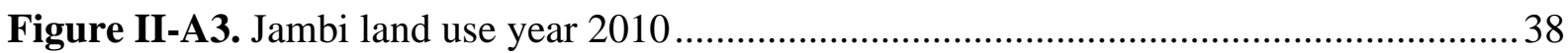

Figure III-1. Percentage changes of price for oil palm fruits and rubber at farm gate .......... 43

Figure III-2. Map of Jambi Province indicating the research villages .................................. 46 


\section{General introduction}

... technology adoption in agriculture is an engine of economic growth and an important way to increase farm productivity and improve food security around the world.

That phrase is stated by Chavas and Nauges, (2020 p.49) in their review on literature investigating technology adoption in agriculture. The innovations are constantly needed to cope with exponential population growth. Hence, the challenges of technology adoption should be taken. Chavas and Nauges (2020) list four main issues in technology adoption. First, the innovations' benefits are not fully understood ex-ante. Second, farmers' adoption strongly depends on external factors such as economic conditions. Third, establishing innovation is a complicated and time-consuming process. Fourth, the innovations' benefit changes overtime. Marra et al. (2003) emphasises three distinct elements influencing technology adoption: (1) farmers' learning process; (2) technologies' uncertainty and riskiness; (3) farmers' risk attitudes.

The complexity of technology adoption in developing countries is aggravated by several factors. First, reciprocal relations between poverty and farmers' risk aversion and high discount rates. Poor farmers who are risk-averse and favour high discount rates do not participate in innovation and are reluctant to make investments. Accordingly, they are eliminated from the innovations' benefits, and hence, stay poor (Brick and Visser, 2015). Second, agricultural insurances can break the poverty-traps, but they are not well implemented or unaffordable (Carter et al., 2017). Third, challenges emerge when farmers produce a controversial crop such as oil palms due to trade-offs between farmers' welfare and environmental degradation, resulting in slow participation in sustainable agriculture (e.g., Grass et al., 2020). Thus, the benefits of environmental conservation that are offered in the far future are not appealing for farmers with short-term future planning (Stevenson et al., 2014). Finally, limited access to information poses another challenge in technology adoption.

This dissertation discusses a topic of technology adoption in agriculture under the consideration of farmers' risk attitudes and time preferences. The study took place in Jambi Province, Sumatra, Indonesia. Three papers are presented here. Chapters II, III, and IV present the first, second, and third paper, respectively. Chapter V presents the general conclusions and proposes outlooks for future research and policy recommendations. In the following, brief introductions for each paper are provided. 


\section{Farmers' adoption of palm oil certifications}

Massive palm oil production is driven by high demands of vegetable oils to produce biofuel, food, and other industrial purposes (Carter et al., 2007; McCarthy and Zen, 2010). Palm oil is more successful due to higher productivity and lower production cost per land area, compared to other vegetables oils (Corley and Tinker, 2016). Starting in 2004, palm oil dominated the market for vegetable oils (Carter et al., 2007). Figure I-1 shows the steep growth of palm oil production, globally. In the last three decades, the palm oil production rose from nine to more than 70 million-tons, which indicates an annual growth rate of 7\% (FAO, 2020).

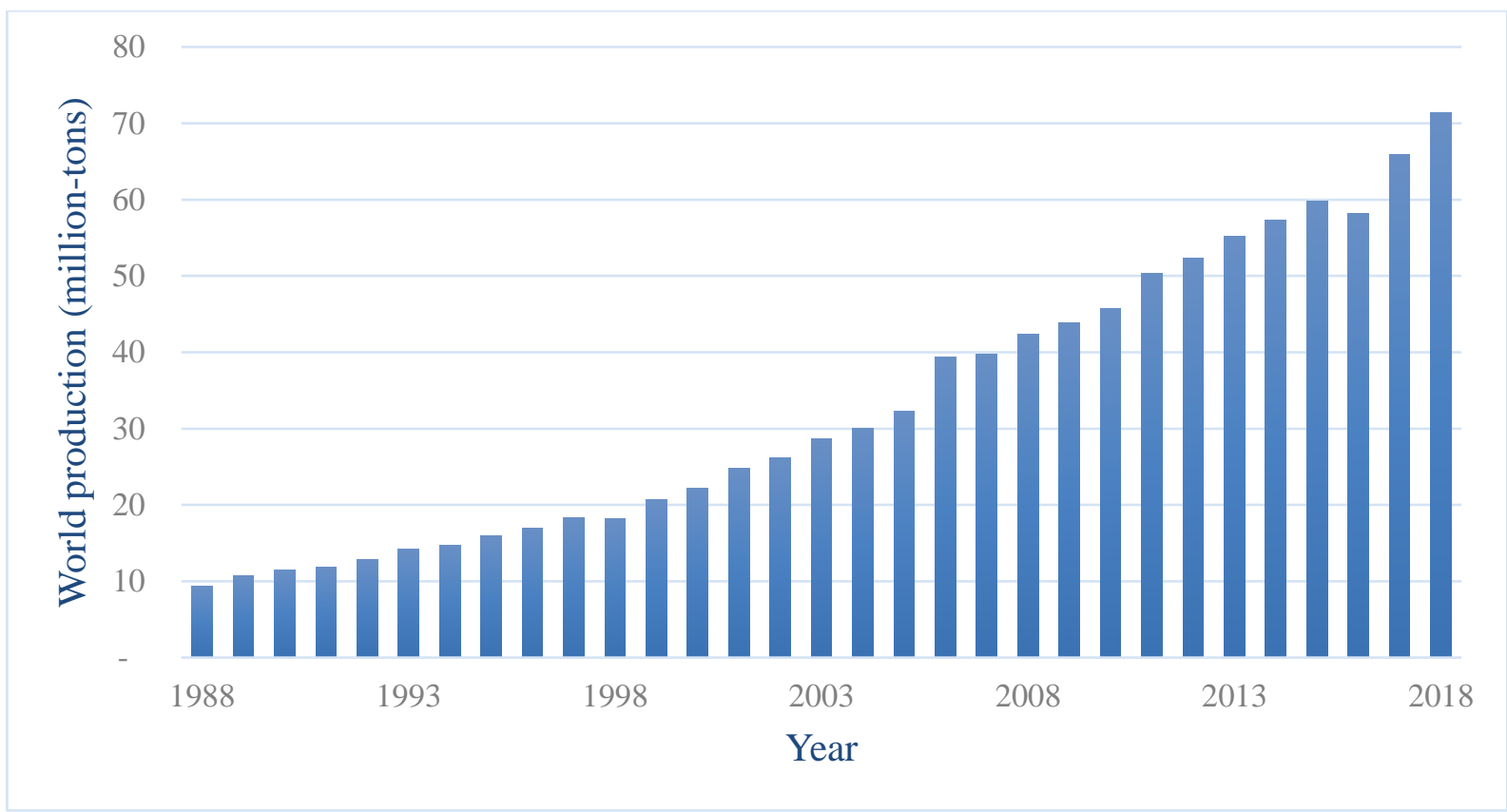

Figure I-1. World production of palm oil Source: FAO (2020)

Currently, Indonesia, Malaysia, Thailand, Colombia, and Nigeria are the top-five palm oil producers. Figure I-2 shows the production of each country (FAO, 2020). Two major producing countries are Malaysia and Indonesia. Until 2005, Malaysia was the biggest producer but in 2006, Indonesia took the position. Since then, Indonesia is the biggest palm oil producer. Alone in 2018, Indonesia contributed to more than $60 \%$ of world production. The Indonesian palm oil production develops rapidly as more areas are established, and more producers participate. The area increased from 0.5 to 6.7 million-hectares within 1988 until 2018 (FAO, 2020). The plantations spread outside of the main island, Java, and the biggest productions take place in Sumatra Island (Feintrenie et al., 2010). The producers consist of big-scale plantations managed 
by the government and private companies as well as small-scale plantations managed by farmers (Euler et al., 2016).

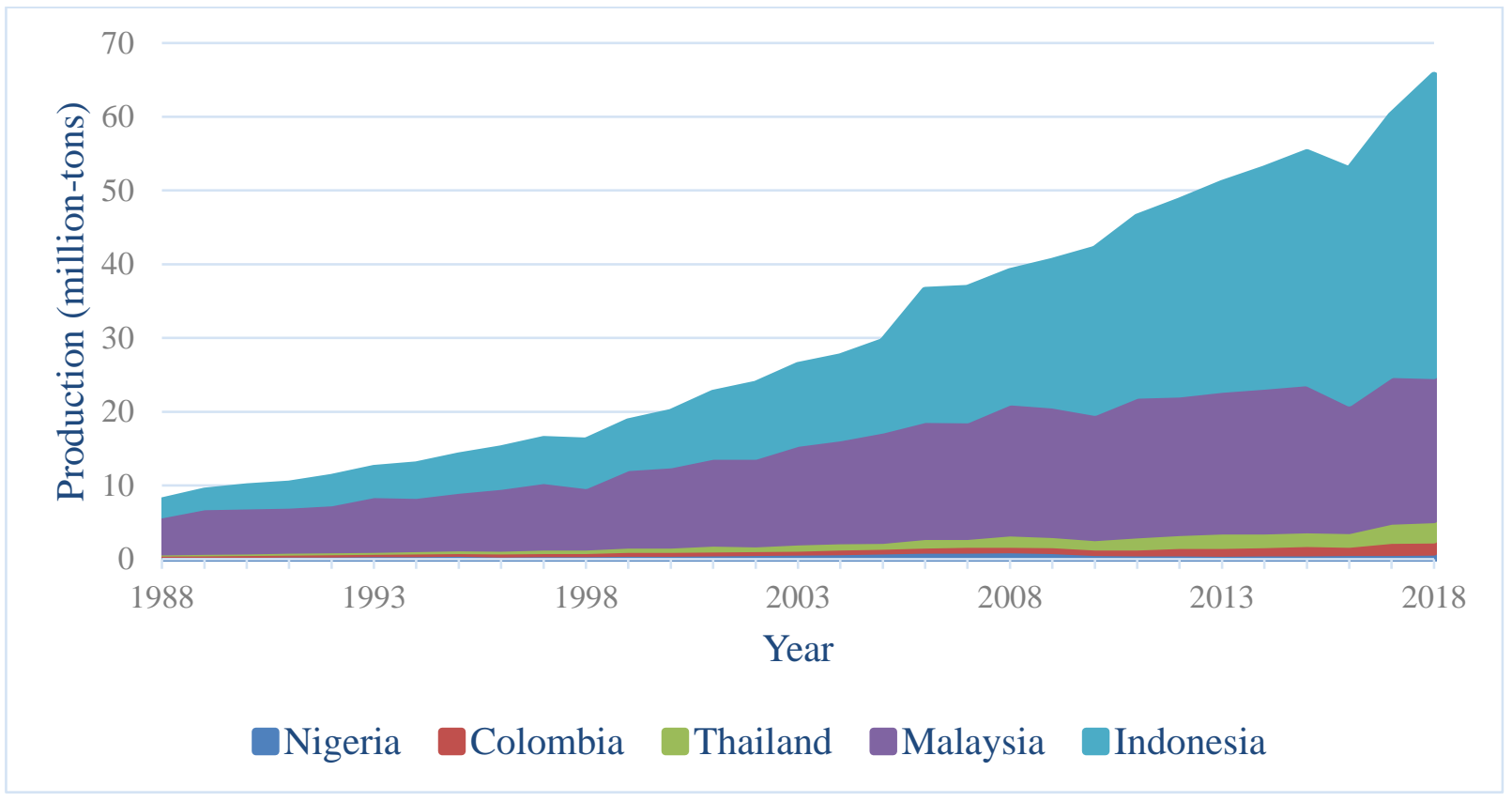

Figure I-2. Top-five producer countries of palm oil Source: FAO (2020)

The oil palm cultivation improves farmers' welfare in terms of higher consumption expenditures and calorie intakes (Euler et al., 2017). As the income of each household increases, the rural poverty also reduces (Rist et al., 2010). However, the palm oil production generates environment issues regarding massive monoculture land use that leads to deforestation (Wilcove and Koh, 2010). Following the deforestation are smoke from forest clearing that worsen the greenhouse gas fluxes. The palm oil production also threatens biodiversity and causes a decline in ecosystem functions (Grass et al., 2020).

Wilcove and Koh (2010) list at least three various attempts to slow down the deforestation and to produce palm oil sustainably including direct regulations, REDD+ payment, and palm oil certification programs. Direct regulation has a disadvantage of the government's double role as policymaker and producers that promote multiple interests during the regulations' enforcement (Wilcove and Koh, 2010). REDD+ stands for Reducing Emission from Deforestation and Degradation in developing countries, which is a set of policies based on the Kyoto-Protocol (Gardner et al., 2012). The success of REDD+ depends strongly on steady and sufficient funding (Wilcove and Koh, 2010). The palm oil certification programs regulate palm oil production in sustainable ways and in exchange, the certified producers will receive a price 
premium. Carlson et al. (2018) proves that the certification is successful in reducing deforestation.

The top two palm oil certifications in Indonesia are the Roundtable on Sustainable Palm Oil (RSPO) and Indonesian Sustainable Palm Oil (ISPO). With the growing environmental concerns in more developed countries (such as in Europe and Australia), large-scale plantations started to produce certified palm oil. However, challenges are met to involve farmers. Obstacles including involvement in deforestation, land disputes, risk aversion, high discount rates, and other external factors inhibiting their participation (e.g., Brandi et al., 2015; Lee et al., 2011; Resosudarmo et al., 2014; Ruysschaert and Salles, 2014; Silva-Castaneda, 2012; Stevenson et al., 2014). Nevertheless, substantial effects of certifications can be achieved only if more farmers participate (Carlson et al., 2018). To date, big shares of oil palm plantation areas are managed by farmers (for example, in Jambi more than 60\%; Grass et al., 2020). Therefore, policies should be implemented to support farmers' participation. A question then emerges: which policy should be implemented?

Paper-1 presents the investigation of three policy scenarios encouraging farmers' participation in the certifications. Those are price premium, provision of environmental information, and communication of group norms. An ex-ante policy-impact-analysis was used to examine the effects of the policy scenarios. We involved 636 farmers and carried out a social dilemma experiment following Andreoni (1995). In this experiment, the farmers were grouped, and each should make either a private purchase or a group investment. The private purchase depicted deforestation and the group investment implied preserving forest. This design confronted them with a dilemma of gaining additional private profits from deforestation or a society wellbeing. The results of this study provide a preliminary insight for policymaker and related agencies while encouraging farmers to participate in the certifications.

\section{Farmers' adoption of a new crop}

Jambi Province is an important province for rubber production and one of the oil palm boom's hotspots in Indonesia. The literature records changes of land use in Jambi Province regarding oil palm after the year 1900. Figure I-3 shows the changes of land use in Jambi based on Ekadinata and Vincent (2011 p. 10). Within 1993-2005, the land cover areas for forest reduced from $42 \%$ to $30 \%$ and rubber agroforest reduced from $15 \%$ to $11 \%$. In contrast, the area for oil palm plantation areas increased from $4 \%$ to $19 \%$. The area for rubber monoculture and other 
purposes remained identical $(26 \%$ - 27\%). In this figure, "other" refers to rice fields, settlements, shrubs, and rivers.

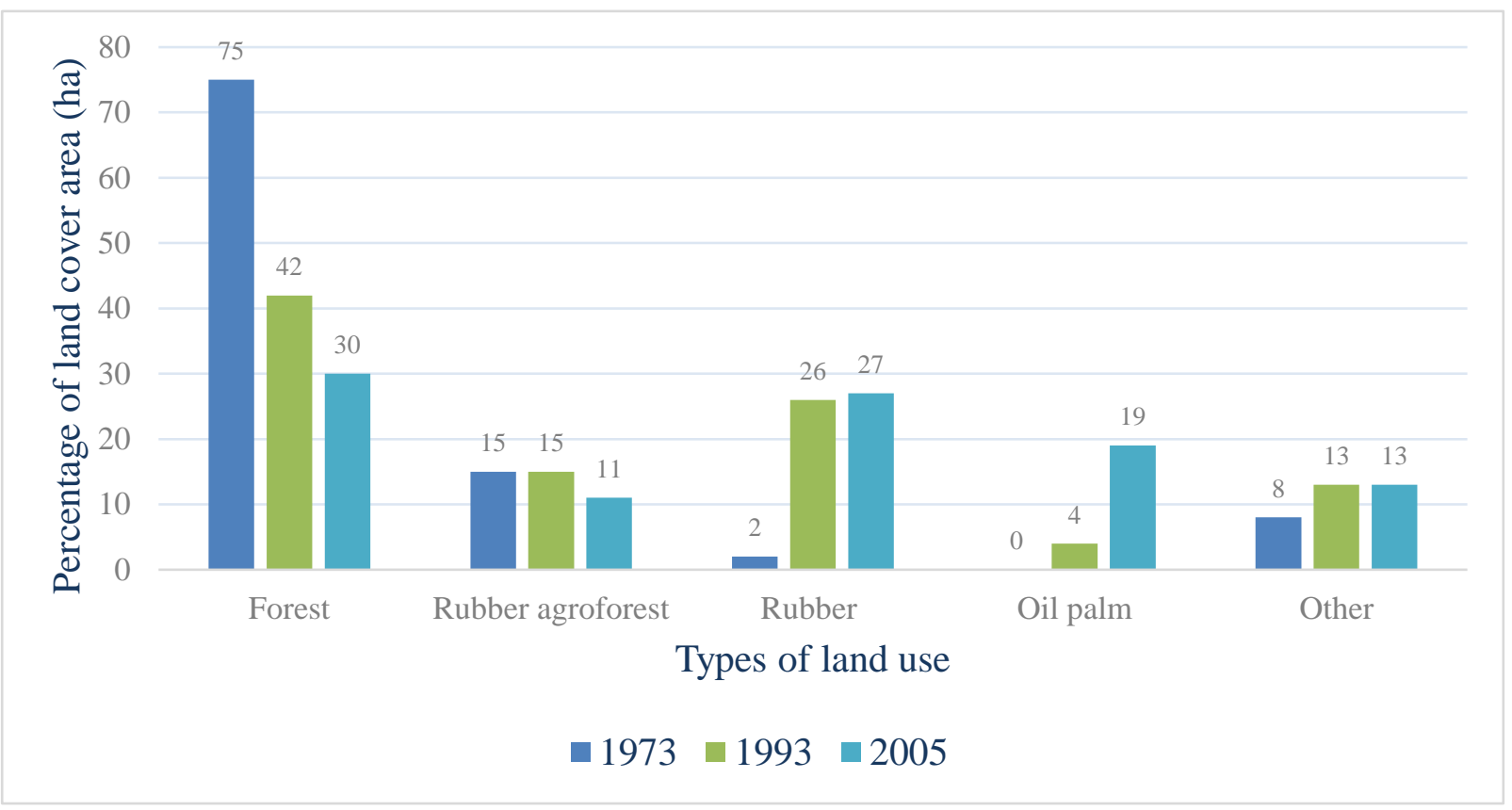

Figure I-3. Land use change in Jambi Province

Source: Ekadinata and Vincent (2011, own illustration)

In Jambi, rubber has been planted for many decades using agroforest and/or monoculture systems. Rubber agroforest is an environmentally land-use practice, where rubber trees are planted among other plants and imitate the rich diversity of plants in forest (Feintrenie and Levang, 2009; Rembold et al., 2017). However, a substantial amount of agroforest is converted into monoculture that gives higher profits (Grass et al., 2020). Oil palm is a relatively newer crop compared to rubber. Oil palm cultivation began with the transmigration program around the year 1900. The transmigration program in Indonesia is a program to relocate people from islands with high population density to less dense island such as Sumatra, Borneo, Sulawesi, and Papua (Fearnside, 1997). This program had an important role in palm oil cultivation in the destined islands ${ }^{1}$.

When the transmigration program and support were gradually decreased, the adoption continued and promoted "independent farmers." Independent farmers are those who cultivate

\footnotetext{
${ }^{1}$ In this program, each participant receives, on average, two hectares of land for settlement, food crop cultivation, and cash crop cultivation, usually oil palms. These lands are near state plantations. This arrangement enables the government' support, including inputs and agricultural extension (Gatto et al., 2015). The government also enforces large-scale private companies to make similar arrangement to support farmers as an exchange for land concession and subsidies. The transmigration program also increases chemical fertilizer usage and develops infrastructures, which accelerates the palm oil production (Gatto et al., 2015).
} 
oil palm without the government's direct support. Until recently, the adoption occurs frequently independently (Euler et al., 2016). Even though rubber is an important cash crop in Jambi, oil palm got an important position in a relatively short time period (Casson and Obidzinski, 2002). This contradicts the previous studies finding farmers' slow adoption of a new crop due to their risk aversion (e.g., Liu, 2013). Farmers' risk aversion creates reluctance to cultivate new crops that needs unfamiliar inputs while they want to be extra careful in managing farms as their main/only isource of income (Dercon and Christiaensen, 2011).

Several studies inform some motivating factors of oil palms' rapid adoption (e.g., Euler et al., 2017; Feintrenie et al., 2010; Kubitza et al., 2018). First, oil palm cultivation is appealing for small size household because it needs fewer working hours than rubber. Second, fewer working hours also mean higher profit per head of labour working in oil palm plantation. Third, cultivating oil palm generates opportunities of off-farms activities. However, if farmers only seek for additional income or higher profits than what they already received from agroforest, converting part of the agroforest to a rubber monoculture should be a safer choice than establishing oil palm plantations. As the oil palm cultivation came later, the rubber cultivation was more familiar. Moreover, rubber monoculture has higher returns per hectare than oil palm (Feintrenie et al., 2010). Therefore, generating extra income is not the only reason of farmers to adopt oil palm, instead the farmers have a desire to produce both rubber and oil palm simultaneously (Euler et al., 2017 p. 221; Feintrenie et al., 2010 p. 391).

Cultivating two or more crop simultaneously, so-called crop-diversification, is meant to reduce income variances during a "bad yield" of one crop (Dercon, 1996). Paper-2 discussed farmers' decision to cultivate two perennial crops (rubber and oil palm) regarding their risk attitudes and time preferences. This paper examines one other motivating factor of oil palm adoption and enriches the literature, which so far discusses merely seasonal/annual cropdiversification (e.g., Bezabih and Sarr, 2012; Chavas and Di Falco, 2012; Dercon, 1996).

In this paper, we propose two hypotheses: (1) more risk-averse farmers cultivate oil palms besides rubber; (2) farmers with a higher discount rate cultivate oil palms besides rubber. We find that farmers who cultivate two crops are more risk-averse than those who cultivate one crops. The discount rates between two groups of farmers are not different, but the discount rates are extremely high.

These findings lead to two different directions of policy. First, if policymaker want farmers to focus on rubber production, which means not supporting crop-diversification. Future policies should favor rubber production by imposing financial incentives for rubber producers such as 
floor prices or agricultural insurances during rainy season. Additionally, the regulation of the rubber price must be enforced because the world price transmits asymmetrically which creates loss for farmers (Kopp et al., 2017). Second, palm oil production should be favored if policymaker want to support the crop-diversification. For example, by increasing the number of mills to accommodate the perishable oil palm fruits.

\section{Farmers' risk attitudes and time preferences}

Farmers' risk attitudes play an important role in technology adoption, where risk-averse farmers create a delay or reduced adoption (Brick and Visser, 2015; Liu, 2013). The decision-makers' risk attitudes are usually measured together with their discount rates (e.g., Andersen et al., 2008; Tanaka et al., 2010). High discount rates are problematic if innovation includes a project with a long-term benefit (Bauer and Chytilová., 2010; Harrison et al., 2005). For instance, this applies to a project related to environmental conservation, such as a sustainable agriculture program. The idea of saving the environment for future generations can be too vague compared to monoculture's income in the closer future (Lee, 2005; Stevenson et al., 2014).

Paper-3 investigates farmers' risk attitudes and time preferences. The dataset of this paper is extended by involving farmers from India. This study involves 772 Indian and 756 Indonesian farmers. A Holt and Laury task (HL-task) and a Coller and Williams task (CW-task) were carried out to observe the risk attitudes and time preferences (Coller and Williams, 1999; Holt and Laury, 2002). The villages in India were located around a city and the villages in Indonesia were in more remote areas. In this circumstance, we can compare whether the farmers' preferences are the same.

To date, studies of farmers' risk attitude and discount rate were conducted usually in a single country (e.g., Bauer et al., 2012; Nguyen, 2011; Tanaka et al., 2010). Likewise, if research was based in two or more countries, they did not focus on farmers (e.g., Falk et al., 2018). Our study was a direct country comparison in one paper without being a review or meta paper. This comes with the advantage that the experimental framework conditions in both countries were perfectly harmonised. For instance, the data collection was conducted at a similar time frame which anticipated changes in the economic conditions, using the same elicitation method (HL-task and CW-task), and focused only on farmers. Furthermore, this study extended on previous research that focused only on risk attitudes or time preferences. For example, Harrison et al. (2009) study, compared farmers' risk attitudes in three different income levels countries but did not discuss the time preferences. The same could be said for the study by Wang et al. (2016) 
which compared the time preferences of students in a laboratory experiment from many countries but neglected the discussion of risk attitude. To focus on the elicitation of risk attitudes and time preferences at the same time is advantageous because it allows risk attitudes to be considered when calculating time preference, rather than assuming risk neutrality. Therefore, this study is novel in terms of involving two countries, risk and time preferences as well as focusing on farmers. 


\section{References}

Andersen S, Harrison GW, Lau MI, Rutström EE. 2008. Eliciting risk and time preference. Econometrica 76(3): 583-618. https://doi.org/10.1111/j.1468-0262.2008.00848.X

Andreoni, J. 1995. Warm-glow versus cold-prickle: The effects of positive and negative framing on cooperation in experiment. The Quarterly Journal of Economics 110(1): 121. https://doi.org/10.2307/2118508

Bauer M, Chytilová J. 2010. The impact of education on subjective discount rate in Ugandan villages. Economic development and cultural change 58(4): 643-669. https://doi.org/10.1086/652475.

Bauer M, Chytilová J, Morduch J. 2012. Behavioral foundations of microcredit: Experimental and survey evidence from rural India. American Economic Review 102(2): 1118-1139. https://doi.org/10.1257/aer.102.2.1118

Bezabih M, Sarr M. 2012. Risk preferences and environmental uncertainty: Implications for crop diversification decisions in Ethiopia. Environmental and Resource Economics 53(4): 483-505. https://doi.org/10.1007/s10640-012-9573-3

Brandi C, Cabani T, Hosang C, Schirmbeck S, Westermann L, Wiese H. 2015. Sustainability standards for palm oil: Challenges for smallholder certification under the RSPO. Journal of Environment and Development 24(3): 292-314. https://doi.org/10.1177/1070496515593775

Brick K, Visser M. 2015. Risk preferences, technology adoption and insurance uptake: A framed experiment. Journal of Economic Behavior \& Organization 118:383-96. https://doi.org/10.1016/j.jebo.2015.02.010

Carlson KM, Heilmayr R, Gibbs HK, Noojipady P, Burns DN, Morton DC, Walker NF, Paoli GD, Kremen C. 2018. Effect of oil palm sustainability certification on deforestation and fire in Indonesia. Proceedings of the National Academy of Sciences 115(1): 121-126. https://doi.org/10.1073/pnas.1704728114

Carter C, Finley W, Fry J, Jackson D, Willis L. 2007. Palm oil markets and future supply. European Journal of Lipid Science and Technology 109(4): 307-314. https://doi.org/10.1002/ejlt.200600256

Carter M, de Janvry A, Sadoulet E, Sarris A. 2017. Index insurance for developing country agriculture: a reassessment. Annual Review of Resource Economics 5(9):421-38. https://doi.org/10.1146/annurev-resource-100516-053352

Casson A, Obidzinski K. 2002. From new order to regional autonomy: Shifting dynamics of "illegal" logging in Kalimantan, Indonesia. World Development 30(12): 2133-2151. https://doi.org/10.1016/S0305-750X(02)00125-0

Chavas JP, Di Falco S. 2012. On the role of risk versus economies of scope in farm diversification with an application to Ethiopian farms. Journal of Agricultural Economics 63(1): 25-55. https://doi.org/10.1111/j.1477-9552.2011.00319.x

Chavas JP, Nauges C. 2020. Uncertainty, learning, and technology adoption in agriculture. Applied Economic Perspectives and Policy 42(1): $42-53$. https://doi.org/10.1002/aepp.13003

Coller M, Williams MB. 1999. Eliciting individual discount rates. Experimental Economics 2(2): 107-127. https://doi.org/10.1023/A:1009986005690

Corley RHV, Tinker PB. 2016. The oil palm: fifth edition. Wiley Blackwell, United Kingdom.

Dercon S. 1996. Risk, crop choice, and savings: Evidence from Tanzania. Economic Development and Cultural Change 44(3): 485-513. https://doi.org/10.1086/452229 
Dercon S, Christiaensen L. 2011. Consumption risk, technology adoption and poverty traps: Evidence from Ethiopia. Journal of development economics, 96(2): 159-173. https://doi.org/10.1016/j.jdeveco.2010.08.003

Ekadinata A, Vincent G. 2011. Rubber agroforests in a changing landscape: analysis of land use/cover trajectories in Bungo district, Indonesia. Forests, Trees and Livelihoods 20(1):3-14. https://doi.org/10.1080/14728028.2011.9756694

Euler M, Krishna V, Schwarze S, Siregar H, Qaim M. 2017. Oil palm adoption, household welfare, and nutrition among smallholder farmers in Indonesia. World Development 93: 219-235. https://doi.org/10.1016/j.worlddev.2016.12.019

Euler M, Schwarze S, Siregar H, Qaim M. 2016. Oil palm expansion among smallholder farmers in Sumatra, Indonesia. Journal of Agricultural Economics 67(3): 658-676. https://doi.org/10.1111/1477-9552.12163

Falk A, Becker A, Dohmen T, Enke B, Huffman D, Sunde U. 2018. Global evidence on economic preferences. The Quarterly Journal of Economics 133(4):1645-1692. https://doi.org/10.1093/qje/qjy013

FAO. 2020. FAOSTAT Production quantity. Accessed on 01.04.2020. Available at: www.fao.org

Fearnside PM. 1997. Transmigration in Indonesia: Lessons from its environmental and social impacts. Environmental Management 21(4): https://doi.org/10.1007/s002679900049

Feintrenie L, Chong WK, Levang P. 2010. Why do farmers prefer oil palm? Lesson learnt from Bungo district, Indonesia. Small-scale Forestry 9(3): 379-396. https://doi.org/10.1007/s11842-010-9122-2

Feintrenie L, Levang P. 2009. Sumatra's rubber agroforests: Advent, rise and fall of a sustainable cropping system. Small-scale Forestry 8(3): 323-335. https://doi.org/10.1007/s11842-009-9086-2

Gardner TA, Burgess ND, Aguilar-Amuchastegui N, Barlow J, Berenguer E, Clements T, Danielsen F, Ferreira J, Foden W, Kapos V, Khan SM, Lees AC, Parry L, Roman-Cuesta RM, Schmitt CB, Strange N, Theilade I, Vieira IGG. 2012. A framework for integrating biodiversity concerns into national REDD+ programmes. Biological Conservation 154:61-71.

Gatto M, Wollni M, Qaim M. 2015. Oil palm boom and land-use dynamics in Indonesia: The role of policies and socioeconomic factors. Land Use Policy 46: 292-303. https://doi.org/10.1016/j.landusepol.2015.03.001

Grass I, Kubitza C, Krishna VV, Corre MD, Mußhoff O, Pütz P, Drescher J, Rembold K, Ariyanti ES, Barnes AD, Brinkmann N, Brose U, Brümmer B, Buchori D, Daniel R, Darras KFA, Faust H, Fehrmann L, Hein J, Hennings N, Hidayat P, Hölscher D, Jochum M, Knohl A, Kotowska MM, Krashevska V, Kreft H, Leuschner C, Lobite NJS, Panjaitan R, Polle A, Potapov AM, Purnama E, Qaim M, Röll A, Scheu S, Schneider D, Tjoa A, Tscharntke T, Veldkamp E, Wollni M. 2020. Trade-offs between multifunctionality and profit in tropical smallholder landscapes. Nature Communications. 11(1):1-3. https://doi.org/10.1038/s41467-020-15013-5

Harrison GW, Lau MI, Rutström EE, Sullivan MB. 2005. Eliciting risk and time preferences using field experiments: Some methodological issues. Field experiments in economics 10: 125-218. https://doi.org/10.1016/s0193-2306(04)10005-7.

Harrison GW, Humphrey SJ, Verschoor A. 2009. Choice under uncertainty: evidence from Ethiopia, India and Uganda. The Economic Journal 120(543): 80-104. https://doi.org/10.1111/j.1468-0297.2009.02303.x

Holt CA, Laury SK. 2002. Risk aversion and incentive effects. American Economic Review 92(5): 1644-1655. https://doi.org/10.1257/000282802762024700 
Kopp T, Brümmer B, Alamsyah Z, Fatricia RS. 2017. Welfare implications of intertemporal marketing margin manipulation. British Food Journal 119(8): 1656-1671. https://doi.org/10.1108/BFJ-11-2016-0572

Krishna V, Kubitza C, Pascual U, Qaim M. 2017. Land markets, property rights, and deforestation: Insight from Indonesia. World Development 99: 335-349. https://doi.org/10.1016/j.worlddev.2017.05.018

Kubitza C, Krishna VV, Alamsyah Z, Qaim M. 2018. The economics behind an ecological crisis: livelihood effects of oil palm expansion in Sumatra, Indonesia. Human Ecology 46(1):107-16. https://doi.org/10.1007/s10745-017-9965-7

Lee DR. 2005. Agricultural sustainability and technology adoption: Issues and policies for developing countries. American journal of agricultural economics 87(5): 1325-1334. https://doi.org/10.1111/j.1467-8276.2005.00826.x.

Lee JSH, Rist L, Obidzinski K, Ghazoul J, Koh LP. 2011. No farmer left behind in sustainable biofuel production. Biological Conservation 144(10): 2512-2516. https://doi.org/10.1016/j.biocon.2011.07.006

Liebenehm S, Waibel H. 2014. Simultaneous estimation of risk and time preferences among small-scale cattle farmers in West Africa. American Journal of Agricultural Economics 96(5): 1420-1438. https://doi.org/10.1093/ajae/aau056.

Liu EM. 2013. Time to change what to sow: Risk preferences and technology adoption decisions of cotton farmers in China. Review of Economics and Statistics. 95(4):1386403. https://doi.org/10.1162/REST_a_00295

Marra M, Pannell DJ, Ghadim AA. 2003. The economics of risk, uncertainty and learning in the adoption of new agricultural technologies: where are we on the learning curve? Agricultural Systems. 75(2-3): 215-34. https://doi.org/10.1016/S0308-521X(02)00066-5

McCarthy J, Zen Z. 2010. Regulating the oil palm boom: Assessing the effectiveness of environmental governance approaches to agro-industrial pollution in Indonesia. Law \& Policy. 32(1): 153-79. https://doi.org/10.1111/j.1467-9930.2009.00312.x

Nguyen Q. 2011. Does nurture matter: Theory and experimental investigation on the effect of working environment on risk and time preferences. Journal of Risk and Uncertainty 43(3): 245-270. https://doi.org/10.1007/s11166-011-9130-4

Rembold K, Mangopo H, Tjitrosoedirdjo SS, Kreft H. 2017. Plant diversity, forest dependency, and alien plant invasions in tropical agricultural landscapes. Biological Conservation 213: 234-242. https://doi.org/10.1016/j.biocon.2017.07.020

Resosudarmo IAP, Atmadja S, Ekaputri AD, Intarini DY, Indriatmoko Y, Astri P. 2014. Does tenure security lead to REDD+ project effectiveness? Reflections from five emerging sites in Indonesia. World Development 55: 68-83. https://doi.org/10.1016/j.worlddev.2013.01.015

Rist L, Feintrenie L, Levang P. 2010. The livelihood impact of oil palm: Smallholders in Indonesia. Biodiversity and Conservation 19(4): 1009-1024. https://doi.org/10.1007/s10531-010-9815-z

Ruysschaert D, Salles D. 2014. Towards global voluntary standards: Questioning the effectiveness in attaining conservation goals, the case of the roundtable sustainable palm oil (RSPO). Ecological Economics 107: 438-446. https://doi.org/10.1016/j.ecolecon.2014.09.016

Silva-Castaneda L. 2012. A forest of evidence: Third-party certification and multiple forms of proof-a case study of oil palm plantation in Indonesia. Agricultural and Human Values 29(3): 361-370. https://doi.org/10.1007/s10460-012-9358-X

Stevenson JR, Serraj R, Cassman KG. 2014. Evaluating conservation agriculture for small-scale farmers in Sub-Saharan Africa and South Asia. Agriculture, Ecosystem and Environment 187: 1-10. https://doi.org/10.1016/j.agee.2014.01.018. 
Tanaka T, Camerer CF, Nguyen Q. 2010. Risk and time preferences: Linking experimental and household survey data from Vietnam. American Economic Review 100(1): 557-71. https://doi.org/10.1257/aer.100.1.557.

Wang M, Rieger MO, Hens T. 2016. How time preferences differ: Evidence from 53 countries. Journal of Economic Psychology 52: 115-135. https://doi.org/10.1016/j.joep.2015.12.001

Wilcove DS, Koh LP. 2010. Addressing the threats to biodiversity from oil-palm agriculture. Biodiversity and Conservation 19(4): 999-1007. https://doi.org/10.1007/s10531-0099760-X 


\title{
II. Discouraging rainforest transformation: an ex-ante policy impact analysis
}

Arieska Wening Sarwosri, Johannes Wegmann, Oliver Mußhoff

This paper has been published in:

Journal of Agricultural Economics, 2020 Vol. 71(1): 219-238

Original submitted August 2018, revision received February 2019, accepted March 2019

DOI: http://doi.org/10.1111/1477-9552.12336

The earlier version of this paper has been published in:

EFForTS Discussion Paper Series, July 2018, No. 23

\begin{abstract}
Despite extensive efforts made by national and international certification agencies, Indonesian farmers' participation of palm oil certification schemes adoption remains low. A fundamental obstacle was the farmers' practice of deforestation which was forbidden by the agencies. In this context, we investigated three policies that could lead to a reduction in rainforest deforestation by farmers: price premium on certified palm oil, the provision of environmental information and, contributor recognition. To evaluate the influence of the policies ex-ante, we conducted a social dilemma experiment involving rubber and oil palm farmers in Jambi Province, Sumatra, Indonesia. The findings indicated that the price premium and provision of context-specific environmental information could reduce rainforest transformation. However, a statistically significant effect of contributor recognition was not found.
\end{abstract}

\section{Keywords:}

Deforestation; ex-ante policy impact analysis; framed field experiment; palm oil certification; social dilemma experiment; Indonesia

JEL Classifications: C93, Q56, Q58 


\section{Introduction}

High global demand for palm oil and its profitability accelerates rainforest conversion to oil palm plantations in Indonesia (Wilcove and Koh, 2010). This creates trade-offs along the value chain between the three dimensions of sustainability, i.e., economic, social, and environmental ${ }^{2}$. On the economic dimension, the palm oil production has considerably increased incomes of oil palm farmers (Euler et al., 2017). On the social dimension, poverty among farmers has reduced as they also benefitted from the palm oil boom (Rist et al., 2010) ${ }^{3}$. On the environmental dimension, however, there are consequences in terms of greenhouse gas emission and the loss of biodiversity (Gatto et al., 2015; Laurance et al., 2010; Wilcove and Koh, 2010). To mitigate the trade-offs between the three dimensions, sustainable palm oil (SPO) certification schemes have been introduced by national and international agencies ${ }^{4}$ to upgrade the palm oil value chain. Such upgrades were designed to tackle all three dimensions of sustainability.

However, SPO schemes have been criticized as transforming the palm oil industry towards more sustainability too slowly. Particularly, the enrolment rates of Indonesian farmers in SPO schemes remain low even though they contribute to $40 \%$ of the entire palm oil production of Indonesia, on average (Noor et al., 2017; UNDP, 2014). Likewise, deforestation still occurs at a substantial extent, creating further trade-offs between the dimensions of sustainability (Euler et al., 2016). There seem to be two major reasons for low participation by farmers in SPO certification. Firstly, rainforest conversion to oil palm plantations is socially accepted among farmers as it improves their household's income (Brandi et al., 2015; Lee et al., 2011; SilvaCastaneda, 2012). Under traditional customs, farmers acquire rainforest from the community without formal land titles (Krishna et al., 2017; Resosudarmo et al., 2014). Accordingly, required documents from the SPO agencies such as formal land titles cannot be provided, inhibiting farmers' participation in certification schemes. Secondly, SPO production by farmers

\footnotetext{
${ }^{2}$ According to the Food and Agriculture Organization, the three dimensions of sustainability are rather broadly defined. Economic sustainability was achieved when an activity was commercially or fiscally viable for all actors or support providers along the value chain. Social sustainability was determined by the ability to achieve an equitable distribution of the additional generated value. Poor households should benefit sufficiently from the upgrade in the value chain. Environmental sustainability refers to the ability of creating a positive impact or at least not a negative impact on the natural environment.

${ }^{3}$ There also exists a trade-off between the economic and social dimension of sustainability which are outside the scope of this study. For example, landownership was disputed between local communities/indigenous communities and producers who were granted access to land by the government (Ministry of Agriculture, 2015).

${ }^{4}$ The certification agencies for sustainable palm oil in Indonesia are: Indonesian Sustainable Palm Oil (ISPO); International Sustainability and Carbon Certification (ISCC); Palm Oil Innovation Group (POIG); Rainforest Alliance (RA)/Sustainable Agriculture Network (SAN); Roundtable on Sustainable Biomaterials (RSB); Roundtable on Sustainable Palm Oil (RSPO); Sustainable Palm Oil Manifesto (SPOM).
} 
is not always financially viable. Profit from rainforest conversion to oil palm plantations often exceed the profit from certification, resulting in prohibitively high opportunity costs for certification (Ruysschaert and Salles, 2014). To reduce opportunity costs, certification agencies pay a price premium for sustainably produced palm oil. However, these price premia are not clearly stated by the agencies (Hidayat et al., 2015). Hence, the question remains whether the price premium effectively alters the behaviour of participants in general and of targeted farmers.

Apart from utilizing price premia to mitigate trade-offs between the economic and environmental dimension, other potential policies to mitigate these trade-offs have not yet been investigated. Another approach could be to increase the social desirability of rainforest preservation, which could be triggered either individually or through peer effects. Providing environmental information could be one tool to alter behaviour on an individual level by encouraging individuals to make a positive contribution to the environment (Steg and Vlek, 2009). Environmental information has been successfully tested to promote pro-environmental behaviour in other contexts such as reduced energy usage (McMakin et al., 2002). Another tool is using group norms to stimulate desired behaviour. Group members are more likely to follow a norm if the group unambiguously signals the desirability of the norm (Steg et al., 2014).

Nevertheless, it was not clear whether these policies could work in the context of rainforest conversion to oil palm plantation in Indonesia. To close the research gap, we analysed different policies to mitigate the trade-offs between the economic and social dimensions and the environmental dimension at smallholder level ${ }^{5}$, i.e., preserved the rainforest while maintaining the economic benefits of palm oil production. As deforestation was one of the biggest obstacles for participation in SPO schemes, such policies could also stimulate farmers' involvement with SPO agencies. We analysed three different policy measures while controlling for household and farm-specific characteristics: (1) the provision of a price premium; (2) strengthening the social desirability of rainforest preservation by providing environmental information; (3) increasing group appreciation of rainforest preservation by contributor recognition.

We used a social dilemma framed field experiment, as was appropriate to evaluate policies $e x$ ante (e.g., Hermann et al., 2017, Moser and Mußhoff, 2016), with 636 farmers in Jambi Province, Sumatra, Indonesia. The experiment assessed deforestation decisions of farmers and evaluated three different policies: price premium for certified palm oil, provision of environmental information and contributor recognition by a group. Jambi Province was chosen as it was one

\footnotetext{
${ }^{5}$ As the economic and social dimensions are closely related at the smallholder level, our research focuses on the trade-offs between economic and environment dimension.
} 
example where a large area of rainforest has been transformed (Drescher et al., 2016). Conducting a framed field experiment with the social group of interest, i.e., with farmers instead of convenience groups such as students, increases the external validity of the experiment (Harrison and List, 2004).

To our knowledge, this is the first paper connecting rainforest preservation policies to SPO certification using an experimental approach. The findings are intended to assist policy makers and certification agencies to increase the participation of farmers in the certification program and hence, increase the production of sustainable palm oil. The paper is structured as follows: Section 2 presents a conceptual framework and the hypotheses which are derived from existing literature. Section 3 introduces the experimental design. The estimation method as well as the results and discussions are presented in section 4 . Finally, section 5 provides the conclusions of the study.

\section{Conceptual framework and derivation of hypotheses}

\subsection{Conceptual framework}

The RSPO (RSPO, 2013) is the largest certification agency, even though there are several other SPO certification schemes (Ruysschaert and Salles, 2014). The RSPO defines economic sustainability in terms of long-term profit, long-term economic and financial viability, including the use of appropriate best practice by growers and millers. This best practice principles embrace criteria for maintaining soil fertility to maintain long-term yields. Social sustainability is defined in terms of improving livelihoods of farmers. For instance, the farmers must comply with the health and safety regulations for the application of chemicals for pest and weed control (RSPO, 2014). The broadly defined corresponding principle is the responsible consideration of employees as well as individuals and communities affected by growers and millers. Environmental sustainability is defined as the conservation of natural resources and biodiversity, including the responsible development of new plantings, which is clearly contradicted by rainforest conversion into oil palm plantations.

\subsection{Derivation of hypotheses}

The cost of establishing and maintaining certified oil palm plantations is higher than the traditional way of cultivation involving slash and burn practices. Thus, it is more profitable for farmers, not to certify unless a sufficient price premium is paid. However, if the expected increased price for certified palm oil is higher than the certification cost, participation would be 
profitable (Engel and Palmer, 2008; Wunder et al., 2008). In other words, low price premia or premium fees for the participation in certification schemes inhibit farmers from participating (Ruysschaert and Salles, 2014). Hence, if the price premium is high enough to compensate for the additional costs of certification, more farmers will take part.

H1. A considerable price premium for certified palm oil decreases deforestation activities of farmers.

Besides the provision of a price premium, the provision of environmental information may encourage individuals to adopt more pro-environmental behaviour (Maibach, 1993; Steg and Vlek, 2009). However, the provision of environmental information could alter the individuals' behaviour only if the knowledge of the problem and the awareness of the individuals are linked (Abrahamse et al., 2005; Bamberg and Möser, 2006). Thus, a good understanding of environmental issues and a strong commitment to preserve the environment alters behaviour (Hines et al., 1986-1987). While this policy measure is relatively common in more developed countries where environmental awareness tends to be higher (e.g., Owens, 2000; Pikett-Baker and Ozaki, 2008), environmental information may also be successful in developing countries depending on factors such as values, local beliefs, personal opinions and the implementation of the content (Arbuthnot, 1977; Corraliza and Berenguer, 2000; Pichert and Katsikopoulos, 2008; Price et al., 2014). If environmental information fits local situations and was easy to understand, it tends to have a positive effect on behaviour towards the environment.

H2. Environmental information which fits the local environmental circumstances increases rainforest preservation of farmers.

Engaging in pro-environmental activities is often motivated by normative reasons such as social approval. Using group or peer dynamics, which stimulated social acceptance can be a useful tool to encourage pro-environmental behaviour (Andreoni and Petrie, 2004; Lacetera and Macis, 2010). Andreoni and Petrie (2004) investigated the influence of a group on public goods contribution and found that revealing each member's contribution increased the total contribution. The results showed the magnitude of the effect was moderate, but Samek and Sheremeta (2014) also confirmed the finding. Therefore, the revelation of contributors to rainforest preservation is expected to have a positive effect on every member in the group.

H3. Contributor recognition increases rainforest conservation of farmers. 


\section{Experimental design}

To test the hypotheses, a framed field experiment with farmers was carried out in Jambi Province, Indonesia. The experiment consisted of two parts. The first part took place in the farmers' residences, where farmers were interviewed to obtain household and farm-specific information. Within the survey, an incentivized Holt and Laury (HL) task was carried out to elicit risk attitudes of the farmers (Holt and Laury, 2002) ${ }^{6}$. In the second part, an incentivized social dilemma experiment with a group of farmers was conducted to investigate the effect of policies on rainforest conservation. The social dilemma experiment took place in the village hall or in the house of the village head. On average, the experiment lasted between one to two hours.

\subsection{Social dilemma experiment design}

Framing the experiment as a rainforest transformation problem made it possible to analyse the major obstacles to farmers' certification, i.e., rainforest clearing which is restricted on the principles and requirements for certifications ${ }^{7}$ (Euler et al., 2016; Krishna et al., 2017). Our social dilemma experiment was designed to model important aspects of the real conditions of rainforest conversion for oil palm plantations. Rainforests were open access resources and transforming them into plantations generates individual benefits. A negative effect of rainforest

\footnotetext{
${ }^{6}$ In the HL-task, there are ten rows of paired lotteries. Each row consists of two options: A and B. Each option has a high and a low lottery payoff. The high and low payoffs in option A are 4,000 Indonesian Rupiah (IDR) and 3,200 IDR. The payoffs for option B are 7,600 IDR and 200 IDR. In option A, the difference between the two gains was less compared to the difference in option B. Thus, option A was called the 'safe option' and option B the 'risky option'. In each row the chance of get the high payoff increases by ten percent, and it starts with a ten percent chance of winning the high payoff in row one. The payoff matrix of the HL-task was presented in the online appendix. For practical reasons, we adopted Ihli et al. (2016) to explain the task since they visualized the HLtask. Images of balls with four different colors inside two closed bags depicted the possible payoffs of the two options: red and yellow representing the high and low payoffs in the safe-option while green and blue the same for the risky-option. Therefore, the proportions of colored balls change according to the probabilities (see on-line Appendix for an example of the questionnaire sheet; see Holt and Laury (2002) for complete instructions of the HL-task). The real monetary incentive was provided for this task. There are two steps to determine the monetary incentives: (1) the farmers took one out of ten numbered-coins from a closed bag which indicated the ten rows of the HL-task. The number in the coin indicates one of the rows where he/she could take one ball. Afterward, we give him/her, either bag A or bag B in that row, depending on their choice as written down in the questionnaire sheet. (2) the farmers draw one ball from the bag. The amount of the voucher was determined according to the color of the ball (see on-line Appendix). Grocery voucher with the payoffs amount were then handed out.

7 The seven principles of ISPO include: legal plantation business permits; plantation management; protection of primary forest and peatland; environmental management and monitoring; responsibility to workers; social responsibility and community economic empowerment; continuous business improvement. The eight principles of RSPO include: commitment on transparency; compliance with applicable existing laws and regulations; commitment to long term economic and financial viability; use of appropriate best practice by plantation and mills; environment responsibility and conservation of natural resources and biodiversity; responsible consideration of employees and of individuals and communities affected by growers and mills; responsible development of new plantings; commitment to continuous improvement in key areas of activity (Ministry of Agriculture, 2015).
} 
exploitation in terms of environmental damages was imposed on everybody in society and thus, made society worse-off (Tietenberg and Lewis, 2012).

We followed the negative framing design by Andreoni (1995), where the participants of the experiment were grouped. Within one group, each participant could make either a private purchase or a group investment. Any decision determined the payoffs of all participants within the group. If one participant made the private purchase, it increased their own payoff, but reduced the payoffs of all other participants in the group. If the participant made a group investment, he/she did not affect another participant's payoff within the group but potentially received less for their own payoff. This setting was repeated several times. The design allowed the participants to preserve the initial payoff and the amount was the same in each round. Groups of four were formed to begin the experiment. The farmers were randomly assigned to groups. The groups' composition remained unknown to the farmers. In the experimental setting, each smallholder had 10 hectares of oil palm plantations which were located next to a rainforest ${ }^{8}$. Each smallholder could either expand their plantation into the rainforest by up to 10 hectares (option A, private purchase) or preserve the rainforest (option B, group investment). Depending on the deforestation decision, the payoff of each smallholder $\left(\pi_{i}\right)$ was determined by:

$\pi_{i}=I+e_{i} p-\sum_{j \neq i} e_{j} p \frac{1}{2}+\left(10-e_{i}\right) \frac{1}{2} p$

The payoff function consisted of different terms as follows:

(1) Payoff from initial plantations

Each hectare of the initial plantation generated 15,000 kilograms of fresh fruit bunches (FFBs). The price of FFBs per kilogram was 1,000 IDR (0.08 US\$). We set the baseline price based on the FFBs price in farm gate on the year 2015 as mentioned in Euler et al., (2015). This was the last information about price of FFBs per kilogram before starting the data collection. The initial plantation generates 150 million IDR as "initial income" $(I)$.

(2) Payoff from expansion

If smallholder $i$ decided to expand their plantation, each additional hectare $(e)$ generated profit $p$ (5 million IDR). This expansion generated less income per hectare than the initial plantation as newly established oil palm plantations generate lower yields.

\footnotetext{
${ }^{8}$ Many farmers started their oil palm plantation by 3.50 hectares (Euler 2016). Nevertheless, the average size of oil palm plantations owned by farmers was highly varied, 0.25-25 hectares of plantation per household (Lee et al., 2014), and the local government defines farmers as those who manage less than 25 hectares of plantations.
} 
(3) Payoff-reduction from expansion of others

For every hectare of transformed rainforest, the smallholder reduced the payoff of every other member in the group by $1 / 2 p$. Likewise, his/her payoff was reduced by $1 / 2 p$ for every hectare of forest transformed by other members in the group.

(4) Return from maintained forest

The smallholder received "return from forest kept" for every hectare of maintained rainforest. As the rainforest transformation may not exceed 10 hectares, the additional profit was given by $(10-e) 1 / 2 p$, i.e., preservation of the forest 'saves' the payoff reduction incurred because of rainforest transformation.

The experiment was repeated six times. After the completion of one repetition, all values were set back to the initial values. Decisions were made simultaneously by all group members. The payoff of each repetition was noted down in a sheet and given back to the participant. Before the experiment began, we explained that real monetary incentives were provided. The incentives were given to encourage sensible and realistic decision making during the experiment ${ }^{9}($ Hertwig and Ortman, 2001).

\subsection{The implementation of policies}

To analyse the effects of policies on deforestation, villages were randomly assigned to three different policy treatments and control villages, where none of our policy measures were implemented. The three policies were independent and thus, it was not possible to compare the magnitude of policies' effect among them directly. After three repetitions of the experiment, the following policies were introduced:

\section{(1) Control}

The experiment as described in sub-section 3.1 was repeated over all six rounds.

(2) Policy 1 - price premium

We added a $50 \%$ price premium to the baseline price if farmers chose not to expand their plantations. The resulting 1,500 IDR (0.11 US\$) per kilogram FFB were considered as a "good price", i.e., a price which makes the plantation economically profitable, by local farmers in Jambi Province (Feintrenie et al., 2010).

(3) Policy 2 - environmental information

\footnotetext{
${ }^{9}$ The real monetary incentives for the social dilemma experiment are given to one of all the farmers in each village. The smallholder who receives the real monetary experiment was selected randomly. This selected smallholder could draw one out of six coins which represent the six rounds of the social dilemma experiment. The smallholder receives the incentive based on their payoff on the selected round, i.e., if the payoff in the round was 175 million IDR, then the incentives was 175,000 IDR.
} 
To design the policy of environmental information, we provided two coloured land-use maps of Jambi Province referring to the years 1990 and 2010 (see Appendix). On both maps, circles of areas with major land-use change from rainforest to oil palm plantations were drawn. However, no further information about negative effects of deforestation was given to avoid potential conflict during the experiment, as the local farmers consider rainforest for oil palm improve their financial conditions as genuine and socially acceptable (Rist et al., 2010).

(4) Policy 3 - contributor recognition

Group composition remained unknown to the farmers for the six rounds of experiment as in control, Policy 1 and Policy 2. To investigate the effect of each group in the Policy 3, we revealed the members of the group in round 4-6. However, the amount of deforested area and payoffs of each member remained confidential.

\subsection{Study region, sample selection and descriptive statistics}

The data collection was conducted in Jambi Province, Sumatra, Indonesia. Jambi is a government's target area to increase rubber production since the 1900s (Fearnside, 1997). Rubber is the main non-food crop that cultivated over generations in Jambi Province (Gouyon et al., 1993; Miyamoto, 2006). Like other provinces in Sumatra, Jambi is also a destination for the transmigration programmes by the government. Together with the transmigration programmes, oil palm has been cultivated there. Within the last three decades, oil palm plantations have been quadrupled while rubber plantations have increased by $25 \%$, substantially decreasing the area of rainforest. In 2013, 55\% of the rainforest area are converted into agricultural land (Drescher et al., 2016; Gatto et al., 2015).

For the study, two sites of lowland rainforest have been identified (Drescher et al., 2016): Bukit Duabelas National Park and Harapan Rainforest. From those two sites, data was collected between October 2016 and January 2017 from five regencies ${ }^{10}$, namely: Batanghari, Bungo, Muara Jambi, Sarolangun, and Tebo. Among those regencies, 40 villages were randomly selected. The number of farmers per village varied between 8 and 24 farmers, depending on the total number of farmers in each village. Farmers were also randomly selected a list of farmers obtained from the village heads or the leader of farmers group. Farmers were randomly selected per village by assigning a random number to each name on the list. Afterwards, random numbers were sorted from largest to smallest and we selected farmers who were mentioned first

\footnotetext{
${ }^{10}$ Regencies are administrative subdivisions which are one level below the provinces.
} 
at the top of the list. In total, 636 farmers who managed oil palm, rubber, or both were selected. Rubber farmers were included because, rubber producers may possibly switch to cultivate oil palm in the future (Gatto et al., 2015).

The descriptive statistics of household and farm-specific variables is shown in Table II-1. Most of the farmers were full time and middle-aged farmers. The majority were male farmers with an average of eight years of formal education. The average duration of rubber farming was much longer than oil palm farming. Only $8 \%$ of farmers were aware about SPO-certification programmes, which supports research observations from Brandi et al. (2015), Lee et al. (2011) and Silva-Castaneda (2012), i.e., farmers have limited knowledge of certification programmes. The variable "risk-attitude" showed information about the number of safe choices in the HLtask. The average number of safe choices was 4.85 and indicates that the farmers were on average slightly risk-averse (Holt and Laury, 2002).

Table II-1. Descriptive statistics of farmers

\begin{tabular}{|c|c|c|}
\hline Variables (units) & Variables' explanations & $\begin{array}{c}\text { Mean (Std. dev.) / } \\
\text { share in } \%\end{array}$ \\
\hline Age (years) & Age of farmer & $46.58(10.47)$ \\
\hline Car $(1 / 0)$ & $=1$ if owns at least one car & $12.11 \%$ \\
\hline Certification knowledge (1/0) & $=1$ if knows about SPO certification & $8.49 \%$ \\
\hline Dependents & Number of non-productive household members & $2.26(1.41)$ \\
\hline Education (years) & Formal education & $8.28(3.61)$ \\
\hline Experience in oil palm (years) & $\begin{array}{l}\text { Age of oil palm plantations (only for farmers who } \\
\text { cultivate oil palm) }\end{array}$ & $4.69(6.89)$ \\
\hline Experience in rubber (years) & $\begin{array}{l}\text { Age of rubber plantations (only for farmers who } \\
\text { cultivate rubber) }\end{array}$ & $15.49(10.76)$ \\
\hline Full-time farmer $(1 / 0)$ & $=1$ if $\geq 50 \%$ income from farming & $86.48 \%$ \\
\hline Loan & $=1$ if has loan within a year & $52.98 \%$ \\
\hline Motorbike & $=1$ if owns at least one motorbike & $98.43 \%$ \\
\hline Oil palm farmers $(1 / 0)$ & $=1$ if cultivates only oil palms & $13.52 \%$ \\
\hline Risk attitude $^{b}$ & Number of safe choices in $\mathrm{HL}$ - task & $4.85(2.38)$ \\
\hline Rubber and then palm oil (1/0) & $=1$ if cultivates rubber and then, oil palm & $27.36 \%$ \\
\hline Saving & $=1$ if has saving within a year & $33.96 \%$ \\
\hline Truck & $=1$ if owns at least one truck & $2.36 \%$ \\
\hline
\end{tabular}

Notes: $\mathrm{N}=636$ farmers; ${ }^{a}$ safe-options in the HL-task: $1-3$ risk-taker, 4 risk-neutral, 5-10 risk-averse

\section{Approach to data analysis and results}

\subsection{Estimation method}

Figure II-1 depicts the average hectares of oil palm expansion in rounds 1 to 6 for the control and the three policy groups. The dashed-vertical line in Figure II-1 indicates the implementation of the policies. It is expected that the expansion in the first three rounds would not be 
statistically significantly different among all groups. The p-value of the Kruskal-Wallis test was 0.46; hence, the Null hypothesis of the test was not rejected, indicating that all groups were identical ${ }^{11}$.

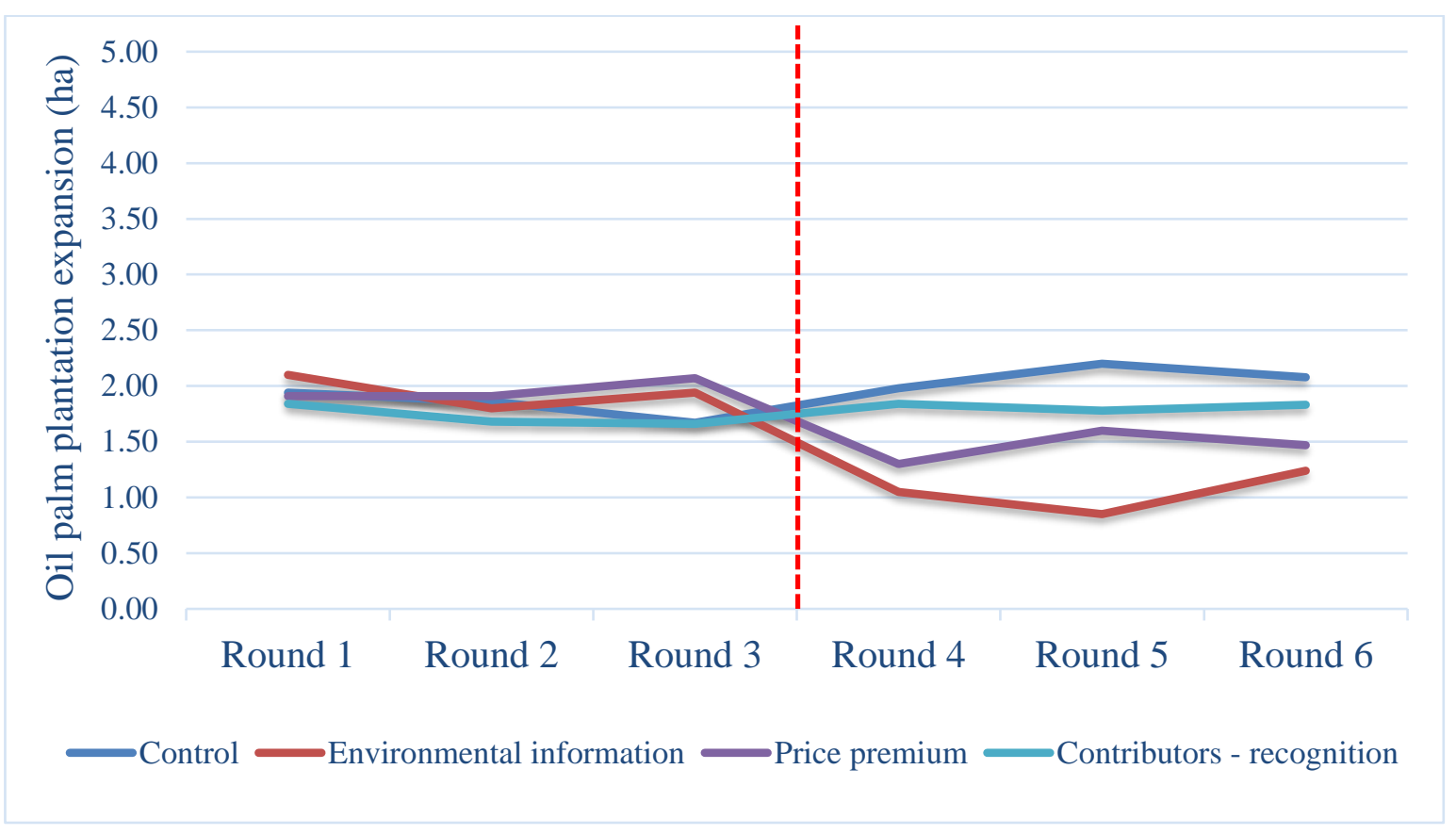

Figure II-1. Oil palm expansion over experiment rounds

Notes: $\mathrm{N}=636$ (68 control, 148 price premiums, 164 environmental information, 156 contributor recognition); The dashed vertical line indicates the policies' implementation

Figure II-2 presents the frequency of the amount of expansions within the six rounds of the task accumulative from the 636 farmers, thus it showed 3,816 decisions. The horizontal axis is the amount of expansions (ha) and the vertical axis is the frequency of the amount of expansion. We denote the dependent variable $\left(Y_{i t}\right)$ indicating the expansion of oil palm plantation by cutting down the forest. This variable is discrete and non-negative and has values from 0 (no deforestation) to 10. Panel data estimation techniques are used to account for the data structure of $t$-times repeated rounds for all $i$ farmers. Given a discrete and non-negative dependent variable, the use of count data models is appropriate to investigate the effect of policies on deforestation in equation (2). From the distribution of oil palm expansion decisions, we estimate the value of standard deviation is equal to 2.98. The value of the standard deviation exceeds the mean (0.13). Thus, an assumption can be made that the data set is negative binomial distributed (Cameron and Trivedi, 2010; Winkelmann, 2008).

\footnotetext{
${ }^{11}$ We also conducted the Kruskal-Wallis test on the repetitions four to six, which are the periods when the policies treatments are at place. The p-value of the Kruskal-Wallis test for this period was 0.00 .
} 


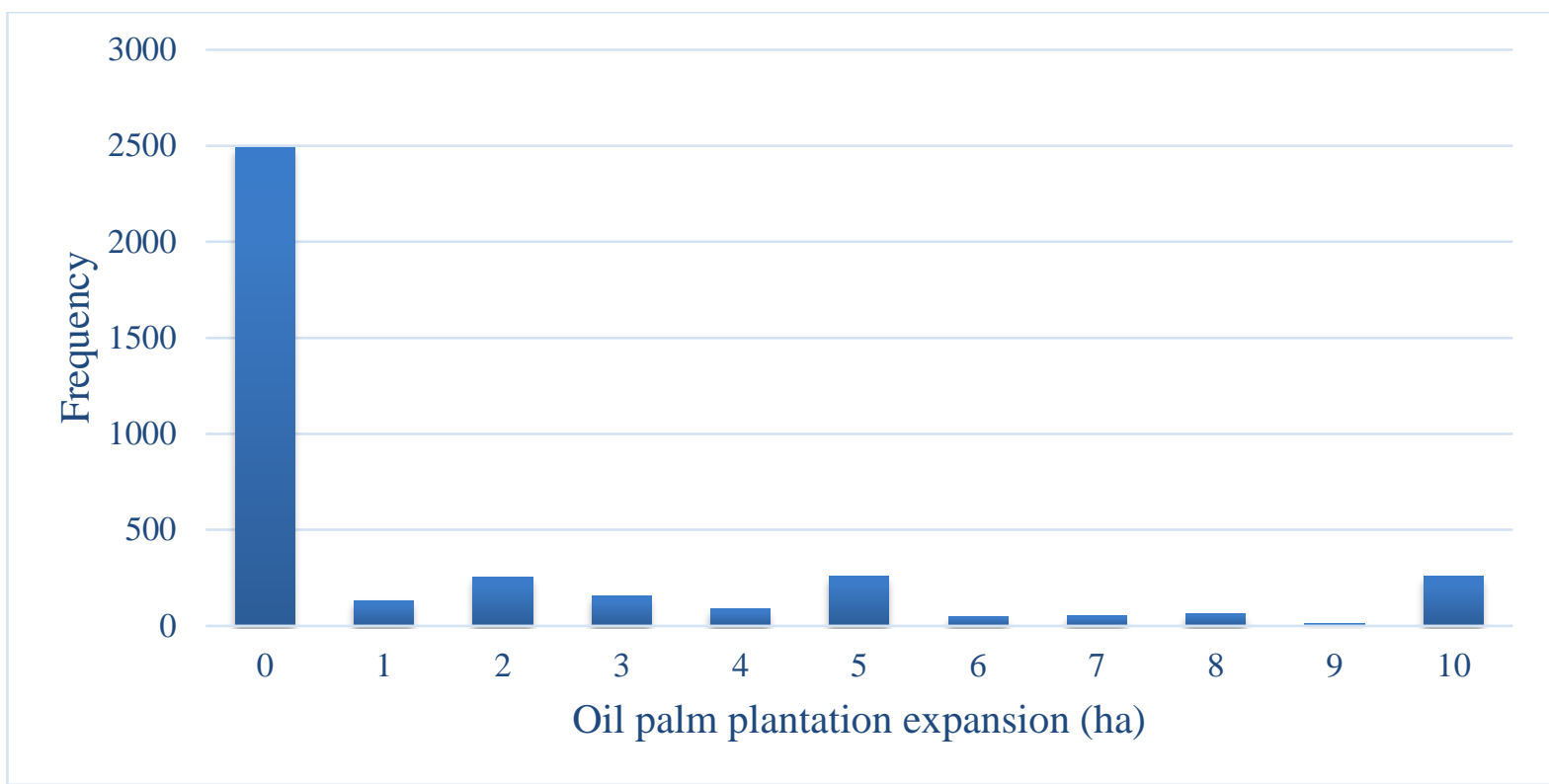

Figure II-2. Distribution of oil palm expansion in the social dilemma experiment Notes: $\mathrm{N}=3,816$ from 636 farmers, 6 rounds of task

To account for time-invariant explanatory variables, we estimate a random effects negative binomial model (Cameron and Trivedi, 2013, Hausman, 1984, Winkelmann, 2008). To account for the over-dispersion, $y_{i t} \mid \lambda_{i t} \sim$ Poisson $\left(\lambda_{i t}\right)$ is assumed, where $\lambda_{i t} \mid \delta_{i} \sim \Gamma\left(\gamma_{i t}, \delta_{i}\right)$. Here $\Gamma(\cdot, \cdot)$ indicates a gamma distribution with $\gamma_{i t}=\exp \left(\boldsymbol{x}_{i t} \boldsymbol{\beta}\right)$ and the over-dispersion parameter $\delta_{i} . \boldsymbol{x}_{i t}$ is a set of explanatory variables. All socio-economic variables as mentioned in Table II-1 and the categorical variable for the policy treatments are included. $\boldsymbol{\beta}$ are their coefficients. Using these assumptions yields the model (Hausman et al., 1984; Winkelmann, 2008):

$\operatorname{Pr}\left(Y_{i t}=y_{i t} \mid x_{i t}, \delta_{i}\right)=\frac{\Gamma\left(\gamma_{i t}+y_{i t}\right)}{\Gamma\left(\gamma_{i t}\right) \Gamma\left(y_{i t}+1\right)}\left(\frac{\delta_{i}}{1+\delta_{i}}\right)^{\lambda_{i t}}\left(\frac{1}{1+\delta_{i}}\right)^{y_{i t}}$

In order to vary $\delta_{i}$ across groups, the assumption $\frac{\delta_{i}}{1+\delta_{i}} \sim \mathrm{B}(\mathrm{r}, \mathrm{s})$ is needed where $\mathrm{B}(\cdot, \cdot)$ indicate a beta distribution with $r$ and $s$ as two shape parameters. Integrating over $\delta_{i}$ yields the joint probability for the $i^{\text {th }}$ individual (Hausman et al., 1984; Winkelmann, 2008):

$$
\operatorname{Pr}\left(y_{i 1}, y_{i 2}, \ldots, y_{i T} \mid \mathbf{X}_{i}\right)=\frac{\Gamma(r+s) \Gamma\left(r+\sum_{t=1}^{T} \gamma_{i t}\right) \Gamma\left(s+\sum_{t=1}^{T} y_{i t}\right)}{\Gamma(r) \Gamma(s) \Gamma\left(r+s+\sum_{t=1}^{T} \gamma_{i t}+\sum_{t=1}^{T} y_{i t}\right)} \prod_{t=1}^{T} \frac{\Gamma\left(\gamma_{i t}+y_{i t}\right)}{\Gamma\left(\gamma_{i t}\right) \Gamma\left(y_{i t}+1\right)}
$$

\subsection{Results and discussions}

To estimate the negative binomial random effects panel model, STATA 14 was used, and the results of the estimations are presented in Table II-2. Column (1) shows the regression results including only policy treatment dummies. Column (2) adds household and farm-specific 
characteristics. Column (3) shows the regression results of a linear random effects model with clustered standard errors at the individual level.

Table II-2. Regression results

\begin{tabular}{|c|c|c|c|}
\hline \multirow{3}{*}{ Variables (units) } & \multicolumn{3}{|c|}{ Coefficients (Std. err.) ${ }^{a}$} \\
\hline & $\begin{array}{l}\text { NBREM without } \\
\text { control variables }\end{array}$ & $\begin{array}{c}\text { NBREM with control } \\
\text { variables }\end{array}$ & $\begin{array}{l}\text { Linear random } \\
\text { effects model }\end{array}$ \\
\hline & (1) & (2) & (3) \\
\hline \multicolumn{4}{|c|}{ Policies (Reference group: control treatment) } \\
\hline Price premium & $-0.73(0.21) * * *$ & $-0.83(0.21) * * *$ & $-0.73(0.33) * *$ \\
\hline Environmental information & $-0.67(0.21) * * *$ & $-0.78(0.22) * * *$ & $-1.13(0.28) * * *$ \\
\hline Contributor recognition & $0.09(0.21)$ & $0.03(0.21)$ & $-0.45(0.31)$ \\
\hline \multicolumn{4}{|c|}{ Socioeconomic and demographic variables } \\
\hline Age (years) & - & $0.00(0.01)$ & $0.01(0.01)$ \\
\hline Car $(1 / 0)$ & - & $0.37(0.25)$ & $0.37(0.35)$ \\
\hline Dependents & - & $0.070 .06)$ & $0.11(0.07)$ \\
\hline Duration of oil palm farming (years) & - & $0.02(0.02)$ & $0.00(0.02)$ \\
\hline Duration of rubber farming (years) & - & $0.01(0.01)$ & $-0.01(0.01)$ \\
\hline Education (years) & - & $-0.02(0.03)$ & $0.02(0.03)$ \\
\hline Full time farmers $(1 / 0)$ & - & $-0.03(0.25)$ & $0.07(0.30)$ \\
\hline Knowledge about certification (1/0) & - & $-0.4(0.30)$ & $-0.07(0.40)$ \\
\hline Loan $(1 / 0)$ & - & $-0.17(0.16)$ & $-0.02(0.18)$ \\
\hline Male $(1 / 0)$ & - & $-0.85(0.42) * *$ & $-1.26(0.68) *$ \\
\hline Motorbike $(1 / 0)$ & - & $-1.08(0.66)$ & $0.55(0.50)$ \\
\hline Oil palm farmers $(1 / 0)$ & - & $-0.17(0.36)$ & $-0.47(0.42)$ \\
\hline Risk attitude $^{a}$ & - & $-0.11(0.03) * * *$ & $-0.09(0.04) * *$ \\
\hline Rubber and palm oil (1/0) & - & $-0.06(0.32)$ & $0.30(034)$ \\
\hline Saving $(1 / 0)$ & - & $-0.30(0.17) *$ & $-0.20(0.22)$ \\
\hline Truck $(1 / 0)$ & - & $0.23(0.51)$ & $0.79(0.76)$ \\
\hline Constant & $0.49(0.17) * * *$ & $2.85(0.93) * * *$ & $2.63(0.98) * * *$ \\
\hline
\end{tabular}

Notes: $\mathrm{N}=1,908 ; 636$ farmers, treatment rounds with three observations each; ${ }^{a}$ Significance levels: $* * *$ at $1 \%$, ** at $5 \%, *$ at $10 \%) ;{ }^{b}$ Safe-options in the HL-task: 1-3 risk-taker; 4 risk-neutral; 5-6 risk-averse

The columns (2) and (3) serve as robustness checks. With respect to our hypotheses all three models provide similar findings: price premium and environmental information sre statistically significantly different from zero with a negative $\operatorname{sign}^{12}$, while contributor recognition is not statistically significant in any of the three regressions. In comparison to the control group, the coefficient for Policy 1 (price premium on certified palm oil) is statistically significantly different from zero at least at the 5\% level and has a negative sign in all three models. In our design of the experiment, farmers only obtained the price premium on their yield from the initial

12 Taking the learning effects into account, we also tested for repetition fixed effects. We found that repetition fixed effects are not statistically significant. The inclusion of repetition fixed effects in the regression does not change the outcome of our regression results. 
plantations if they chose not to deforest. Our results hence showe that if a 50\% price premium is given, farmers reduce their deforestation activities compared to deforestation in control group. Up to now, the certification agencies do not clearly state mark-ups for certified palm oil. A study mentions that mills in Indonesia would pay a mark-up price of 5\% per $\mathrm{kg}$ of FFB (Hidayat, 2015). Other study mentions that price premiums range between $8 \%$ and $15 \%$ (VonGeibler, 2013). The price premiums do not often cover for all expenses made by farmers to get the certificate and this is one of the reasons why participation in SPO certification schemes were low (Lee et al., 2014). Therefore, we chose a price premium of 50\%. This allowed us to study the behaviour of farmers' participation in a SPO scheme under a price premium which was considered as a "good price" (Feintrenie et al., 2010). Our results support the argument that if certified palm oil provides higher profit than the expected additional income from newly developed plantation on rainforest area, then producers would not develop new oil palm plantation in rainforest areas (Bateman et al., 2010; Corley and Tinker, 2016; Hidayat et al., 2015; Schouten and Glasbergen, 2011). Therefore, we support Hypothesis 1 that a price premium on certified palm oil has a positive effect on rainforest conservation and therefore on participation rates of farmers.

When discussing price premiums, one also must take the demand side into account. There are doubts that the market would purchase SPO due to its higher price (Laurance et al., 2010). Nevertheless, since the inaugural conference of RSPO in 2003 (Schouten and Glasbergen, 2011), the demand of certified palm oil has increased by more than 50\% (Von-Geibler, 2013). The European Union plan to use only certified palm oil for biodiesel production and many large companies are committed to only purchasing certified palm oil (Ruysschaert and Salles, 2014). The increasing market demand enable small-scale producers to participate in SPO schemes (Carlson et al., 2018; Vijay et al., 2016).

Considering the effect of Policy 2 (environmental information), the coefficient is statistically significantly different from zero at the $1 \%$ level with a negative sign in all three regression models, indicating that Policy 2 mitigates and/or eliminates deforestation compared to deforestation in control group. The success of environmental information to promote proenvironmental behaviour has been discussed in the literature before (Kollmuss and Agyeman, 2002; Steg and Vlek, 2009). For instance, McMakin et al., (2002) utilized campaigns and focus group discussion to deliver information about energy conservation without financial incentives. A study by McMakin et al. (2002) found a reduction of $10 \%$ energy consumption by households in Washington, USA. Our study finds that environmental information could be effective to 
reduce farmers' decisions to deforest. Policies that addressed the main obstacle of certification, i.e., rainforest deforestation, may increase farmers' participation in the certification programmes. Hypothesis 2 is supported.

The regression results indicated that the coefficient for Policy 3 (contributor recognition) is not statistically significantly different from zero. This finding is opposite to previous results of Andreoni and Petrie (2004) and Samek and Sheremeta (2014). These two studies find that the contributor recognition increase the likelihood to invest in a public good. Both have been conducted in the USA involving undergraduate students. Different backgrounds and contexts may be the reasons for different results on the implementation of the policy to the Indonesian farmers. For the farmers in Indonesia, oil palm cultivations are attempts to improve their households' income and hence, rainforest clearance for oil palm plantation is socially accepted (Krishna et al., 2017; Resosudarmo et al., 2014; Rist et al., 2010). Under these circumstances, there is no social approval for rainforest conservation and contributor recognition does not reinforce normative reasons to behave pro-environmentally. Therefore, Hypothesis 3 cannot be supported, suggesting that recognition of contributors might not be effective in raising participation rates of certification programmes in this context.

Furthermore, to ensure the robustness of the results, household and farm-specific characteristics were included in the regression model. The results are presented in column (2) and (3) of the Table II-2. First, we find that gender mattered in the decisions of rainforest conservation. The dummy variable "male" is statistically significantly different from zero and negative, indicating that male farmers are less likely to deforest than female farmers, on average. At first sight, this result is counterintuitive as most literature showed that women tend to have a higher environmental concern (Arcury and Christianson, 1990; Stern et al., 1995; Zelezny et al., 2000). However, Villamor et al. (2014) find that women in Jambi Province are more concerned to make individual profit, and more readily decide to convert rainforest into monoculture farming such as rubber and oil palm than men. Our experiment also indicates that women farmers more frequently willing to expand their create oil palm plantation than men.

We also find that risk attitudes influenced the decision of preserving the environment (Claassen et al., 2008). In our regression, risk attitudes are statistically significantly different from zero with a negative sign - more risk-averse farmers deforest less, reflecting the risks associated with new oil palm plantations. According to Djanibekov and Villamor (2017), Sumatran farmers are concerned about the uncertainty of future land-use returns, opting not to deforest and stick to the safe returns from the initial plantation. The results in column (2) and 
(3) of Table II-2 provide similar results. The signs of all statistically significant coefficients do not change. This underlines the robustness of the results in column (2). Although the coefficient for savings is statistically significant in column (2), indicating that a lower saving leads to lower deforestation, this significance drops out of the $10 \%$ significance level in column (3). Any conclusion on this variable cannot be drawn because of the missing statistical significance.

\section{Conclusions}

The sustainable palm oil (SPO) certification programme has been established to mitigate tradeoffs between the economic, social, and environmental dimensions of sustainability of palm oil production. It is designed to reduce environmental damages due to rainforest deforestation for palm oil production. However, these programmes have further room for improvement especially in terms of increasing farmers' participation since they apply to only $40 \%$ of palm oil production in Indonesia. We analysed three different policies which could mitigate tradeoffs between economic and the social dimensions of sustainability and environmental sustainability at the smallholder level in Indonesia. Our policies are: (1) a price premium for SPO; (2) the provision of environmental information; (3) contributor's recognition on their potential to engage in pro-environmental behaviour.

Firstly, our results show that a price premium of 50\% successfully reduce the trade-offs between the economic and environmental dimensions, i.e., economic viability and rainforest conservation. In Indonesia, the price of oil palm fruits is determined weekly, based on a meeting with Dinas Perkebunan (Plantation Agency) under the Ministry of Agriculture. Yet the price of certified palm oil is not regulated. This provided room for companies to determine freely the price of certified palm oil. The price often did not cover additional costs for certification (Hidayat $e t$ $a l ., 2015)$. The government of Indonesia and the certification agencies, therefore, should consider evaluating the current price premiums for certified palm oil. Empirical evidence from our research showed that provision of a sufficient price premium encourages more farmers to subscribe to an SPO scheme.

Secondly, our results suggest that providing information on environmental conditions to farmers has a positive effect on their decisions about rainforest conservation, assisting the mitigation between the economic and environmental sustainability dimensions. In this case, depiction of the land-use change by maps of Jambi Province appears to be well understood by our participating farmers. Although rainforest loss was still high and seems to be socially acceptable (Brandi et al., 2015; Lee et al., 2011; Silva-Castaneda, 2012), our results suggest that 
the provision of environmental information encourages farmers' awareness and care about rainforest conservation. Future work can explore this complex issue and address the issue by analysing a policy which aims to make the community more aware about the importance of rainforests. However, SPO agencies should take the provision of environmental information into account when campaigning for their cause.

Thirdly, the effect of contributor recognition, i.e., revealing the members of the group, has no significant effect in reducing the rainforest deforestation in Jambi. In our case, the social acceptability of environmental damage did not seem to be easily solved by recognition of contributors.

Our study shows the implementation of certain policies discourage rainforest transformation for oil palm plantations. Nevertheless, the successful implementation of SPO certifications is only assured when all actors in the value chain participate. Using the social dilemma experiment to examine several policies can be a meaningful entry-point for further research involving other actors along the value chain to SPO schemes. Focusing on farmers provides a first entry point for mitigating trade-offs between the economic, social, and environmental dimensions of sustainability. However, governance of the value chain is more complex. There are several other points of entry for governance, which exceed the scope of this paper. For example, export regulation of palm oil can be imposed at a national level such that only SPO is allowed for export. Moreover, consumers have a large bargaining power over producers (Demont and Rutsaert, 2017). Raising their awareness on the benefits of SPO will probably have major impacts. World demand for SPO has increased substantially over the past years (Von-Geibler, 2013) and many large companies were committed to only purchasing certified palm oil (Ruysschaert and Salles, 2014). For this reason, another entry point for future work can be how the governance power of the consumers could be transmitted through substantial increases in the price premium paid to primary producers.

As farmers also benefitted from the increasing demand for palm oil, the social sustainability dimension is partly represented by the economic dimension. Nevertheless, the social dimension embraces more than just improvements in income for farmers. Future studies can investigate how landownership disputes could be settled without generating a trade-off between the social and economic dimension of sustainably. While our results are specific to Indonesia and to local beliefs and needs, we suspect that they may also apply elsewhere, though this needs confirmation by further research. 


\section{References}

Abrahamse W, Steg L, Vlek C, Rothengatter T. 2005. A review of intervention studies aimed at household energy conservation. Journal of Environmental Psychology 25(3): 273-291. https://doi.org/10.1016/j.jenvp.2005.08.002

Andreoni, J. 1995. Warm-glow versus cold-prickle: The effects of positive and negative framing on cooperation in experiment. The Quarterly Journal of Economics 110(1): 121. https://doi.org/10.2307/2118508

Andreoni J, Petrie R. 2004. Public goods experiments without confidentiality: A glimpse into fund-raising. Journal of Public Economics 88(7-8): 1605-1623. https://doi.org/10.1016/s0047-2727(03)00040-9

Arbuthnot, J. 1977. The roles of attitudinal and personality variables in the prediction of environmental behavior and knowledge. Environment and Behavior 9(2): 217-232. https://doi.org/10.1177/001391657792004

Arcury TA, Christianson EH. 1990. Environmental worldview in response to environmental problems: Kentucky 1984 and 1988 compared. Environment and Behavior 22(3): 387407. https://doi.org/10.1177/0013916590223004

Bamberg S, Möser G. 2006. Twenty years after Hines, Hungerfor, and Tomera: A new metaanalysis of psycho-social determinants of pro-environmental behaviour. Journal of Environmental Psychology 27(1): 14-25. https://doi.org/10.1016/j.jenvp.2006.12.002

Bateman IJ, Fisher B, Fitzherbert E, Glew D, Naidoo R. 2010. Tigers, markets and palm oil: Market potential for conservation. Oryx 44(2): 230-234. https://doi.org/10.1017/s0030605309990901

Brandi C, Cabani T, Hosang C, Schirmbeck S, Westermann L, Wiese H. 2015. Sustainability standards for palm oil: Challenges for smallholder certification under the RSPO. Journal of Environment and Development 24(3): $292-314$. https://doi.org/10.1177/1070496515593775

Cameron AC, Trivedi PK. 2010. Microeconometrics using Stata. Stata Press, Texas, United States of America.

Cameron AC, Trivedi PK. 2013. Regression Analysis of Count Data, 2nd edition. Econometric Society Monograph No.53: Cambridge University Press.

Carlson KM, Heilmayr R, Gibbs HK, Noojipady P, Burns DN, Morton DC, Walker NF, Paoli GD, Kremen C. 2018. Effect of oil palm sustainability certification on deforestation and fire in Indonesia. Proceedings of the National Academy of Sciences 115(1): 121-126. https://doi.org/10.1073/pnas.1704728114

Claassen R, Cattaneo A, Johansson R. 2008. Cost-effective design of agri-environmental payment programs: US experience in theory and practice. Ecological Economics 65(4): 737-752. https://doi.org/10.1016/j.ecolecon.2007.07.032

Corley RHV, Tinker PB. 2016. The oil palm: fifth edition. Wiley Blackwell, United Kingdom.

Corraliza JA, Berenguer J. 2000. Environmental values, beliefs, and actions. Environment and Behavior. 32(6): 832-848. https://doi.org/10.1177/00139160021972829

Demont M, Rutsaert P. 2017. Restructuring the Vietnamese rice sector: Towards increasing sustainability. Sustainability 9(2): 325. https://doi.org/10.3390/su9020325

Djanibekov U, Villamor GB. 2017. Market-based instruments for risk-averse farmers: Rubber agroforest conservation in Jambi Province, Indonesia. Environmental and Development Economics 22(2): 133-155. https://doi.org/10.1017/s1355770x16000310

Drescher J, Rembold K, Allen K, Beckschäfer P, Buchori D, Clough Y, Faust H, Fauzi AM, Gunawan D, Hertel D, Irawan B, Jaya INS, Klarner B, Kleinn C, Knohl A, Kotowska MM, Krashevska V, Krishna V, Leuschner C, Lorenz W, Meijide A, Melati D, Nomura 
M, Perez-Cruzado C, Qaim M, Siregar IZ, Steinebach S, Tjoa A, Tscharntke T, Wick B, Wiegand K, Kreft H, Scheul S. 2016. Ecological and socio-economic functions across tropical and land use system after rainforest conversion. Philosophical Transactions of the Royal Society B: Biological Sciences 371: 1-8. https://doi.org/10.1098/rstb.2015.0275

Engel S, Palmer C. 2008. Payments for environmental services as an alternative to logging under weak property rights: The case of Indonesia. Ecological Economics 65(4): 799809. https://doi.org/10.1016/j.ecolecon.2007.07.028

Euler M, Schwarze S, Siregar H, Qaim M. 2015. Oil palm expansion among smallholder farmers in Sumatra, Indonesia. EFForTS discussion paper series. 8, Georg-AugustUniversität-Göttingen pp. 1-24.

Euler M, Schwarze S, Siregar H, Qaim M. 2016. Oil palm expansion among smallholder farmers in Sumatra, Indonesia. Journal of Agricultural Economics 67(3): 658-676. https://doi.org/10.1111/1477-9552.12163

Euler M, Krishna V, Schwarze S, Siregar H, Qaim M. 2017. Oil palm adoption, household welfare, and nutrition among smallholder farmers in Indonesia. World Development 93: 219-235. https://doi.org/10.1016/j.worlddev.2016.12.019

Fearnside PM. 1997. Transmigration in Indonesia: Lessons from its environmental and social impacts. Environmental Management 21(4): https://doi.org/10.1007/s002679900049

Feintrenie L, Chong WK, Levang P. 2010. Why do farmers prefer oil palm? Lesson learnt from Bungo district, Indonesia. Small-scale Forestry 9(3): 379-396. https://doi.org/10.1007/s11842-010-9122-2

Gatto M, Wollni M, Qaim M. 2015. Oil palm boom and land-use dynamics in Indonesia: The role of policies and socioeconomic factors. Land Use Policy 46: 292-303. https://doi.org/10.1016/j.landusepol.2015.03.001

Gouyon A, De Foresta H, Levang P. 1993. Does 'jungle rubber' deserve its name? An analysis of rubber agroforestry system in southeast Sumatra. Agroforestry System 22(3): 181-206. https://doi.org/10.1007/bf00705233

Harrison GW, List JA. 2004. Field experiments. Journal of Economic Literature 42(4): 10091055. https://doi.org/10.1257/0022051043004577

Hausman J, Bronwyn HH, Griliches Z. 1984. Econometric models for count data with application to the patents-R\&D relationship. Econometrica 52(4): 909-938. https://doi.org/10.2307/1911191

Hermann D, Sauthoff S, Mußhoff O. 2017. Ex-ante evaluation of policy measures to enhance carbon sequestration in agricultural soils. Ecological Economics 140: 241-250. https://doi.org/10.1016/j.ecolecon.2017.05.018

Hertwig R, Ortman A. 2001. Experimental practices in economics: A methodological challenge for psychologist? Behavioral and Brain Sciences 24(3): 383-451.

Hidayat NK, Glasbergen P, Offermans A. 2015. Sustainability certification and palm oil smallholders' livelihood: A comparison between scheme smallholders and independent smallholders in Indonesia. International Food and Agribusiness Management Review 18(3): 25-48.

Hines JM, Hungerford HR, Tomera AN. 1986-1987. Analysis and synthesis of research on responsible environmental behavior: A meta-analysis. Journal of Environmental Education 18(2): 1-8. https://doi.org/10.1080/00958964.1987.9943482

Holt CA, Laury SK. 2002. Risk aversion and incentive effects. American Economic Review 92(5): 1644-1655. https://doi.org/10.1257/000282802762024700

Ihli HJ, Chiputwa B, Mußhoff O. 2016. Do changing probabilities or payoffs in lottery-choice experiments affect risk preference outcomes? Evidence from rural Uganda. Journal of Agricultural and Resource Economics 41: 324-345. 
Kollmuss A, Agyeman J. 2002. Mind the gap: Why do people act environmentally and what are the barriers to pro-environmental behaviour. Environmental Education Research 8(3): 239-260. https://doi.org/10.1080/13504620220145401

Krishna V, Kubitza C, Pascual U, Qaim M. 2017. Land markets, property rights, and deforestation: Insight from Indonesia. World Development 99: 335-349. https://doi.org/10.1016/j.worlddev.2017.05.018

Lacetera N, Macis M. 2010. Social image concerns and prosocial behavior: Field evidence from a nonlinear incentive scheme. Journal of Economic Behavior and Organization 76(2): 225-237. https://doi.org/10.1016/j.jebo.2010.08.007

Laurance WF, Koh LP, Butler R, Sodhi NS, Bradshaw CJ, Neidel JD, Consunji H, Mateo Vega J. 2010. Improving the performance of the roundtable on sustainable palm oil for nature conservation. Conservation Biology 24(2): 377-381. https://doi.org/10.1111/j.15231739.2010.01448.x

Lee JSH, Rist L, Obidzinski K, Ghazoul J, Koh LP. 2011. No farmer left behind in sustainable biofuel production. Biological Conservation 144(10): 2512-2516. https://doi.org/10.1016/j.biocon.2011.07.006

Lee JSH, Ghazoul J, Obidzinski K, Koh L.P. 2014. Oil palm smallholder yields and incomes constrained by harvesting practices and type of smallholder management in Indonesia. Agronomy for Sustainable Development, 34: 501-513. https://doi.org/10.1007/s13593013-0159-4

Maibach, E. 1993. Social marketing for the environment: Using information campaigns to promote environmental awareness and behavior change. Health Promotion International 8(3): 209-224. https://doi.org/10.1093/heapro/8.3.209

McMakin AH, Malone EL, Lundgren RE. 2002. Motivating residents to conserve energy without financial incentives. Environment and Behavior 34(6): 848-863. https://doi.org/10.1177/001391602237252

Ministry of Agriculture. 2015. Joint study on the similarities and differences of the ISPO and the RSPO certification systems. Accessed on: 01.05.2019. Available at: https://www.undp.org/content/dam/gp-commodities/docs/ISPO-

RSPO\%20Joint\%20Study_English_N\%208\%20for\%20screen.pdf

Miyamoto, M. 2006. Forest conversion to rubber around Sumatran villages in Indonesia: Comparing the impacts of road construction, transmigration projects and population. Forest Policy and Economics 9(1): 1-12. https://doi.org/10.1016/j.forpol.2005.01.003

Moser S, Mußhoff O. 2016. Ex-ante evaluation of policy measures: Effects of reward and punishment for fertilizer reduction in palm oil production. Journal of Agricultural Economics 67(1): 84-104. https://doi.org/10.1111/1477-9552.12114

Noor FMM, Gassner A, Terheggen A, Dobie P. 2017. Beyond sustainability criteria and principles in palm oil production: Addressing consumer concerns through insetting. Ecology and Society 22(2): 1-13. https://doi.org/10.5751/es-09172-220205

Owens, S. 2000. Engaging the public: Information and deliberation in environmental policy. Environment and Planning A: Economy and Space 32(7): 1141-1148. https://doi.org/10.1068/a3330

Pichert D, Katsikopoulos KV. 2008. Green defaults: Information presentation and proenvironmental behaviour. Journal of Environmental Psychology 28(1): 63-73. https://doi.org/10.1016/j.jenvp.2007.09.004

Pikett-Baker J, Ozaki R. 2008. Pro-environmental products: Marketing influence on consumer purchase decision. Journal of Consumers Marketing 25(5): 281-293. https://doi.org/10.1108/07363760810890516 
Price JC, Walker IA, Boschetti F. 2014. Measuring cultural values and beliefs about environment to identify their role in climate change response. Journal of Environmental Psychology 37: 8-20. https://doi.org/10.1016/i.jenvp.2013.10.001

Resosudarmo IAP, Atmadja S, Ekaputri AD, Intarini DY, Indriatmoko Y, Astri P. 2014. Does tenure security lead to REDD+ project effectiveness? Reflections from five emerging sites in Indonesia. World Development 55: 68-83. https://doi.org/10.1016/j.worlddev.2013.01.015

Rist L, Feintrenie L, Levang P. 2010. The livelihood impact of oil palm: Smallholders in Indonesia. Biodiversity and Conservation 19(4): 1009-1024. https://doi.org/10.1007/s10531-010-9815-z

RSPO. 2013. Indonesian national interpretation of RSPO principles and criteria 2013. Accessed on 04.12.2017. Available at: https://www.rspo.org/keydocuments/ certification/rspo-national-interpretations

RSPO. 2014. Impact report 2014. Accessed on 14.01.2019 Available at: https://www.rspo.org/file/14_0082RoundtableonSustainablePalmOil(RSPO)ImpactReport 2014v14-spread.pdf.

Ruysschaert D, Salles D. 2014. Towards global voluntary standards: Questioning the effectiveness in attaining conservation goals, the case of the roundtable sustainable palm $\begin{array}{lllll}\text { oil (RSPO). Ecological 107: } & \text { Economics }\end{array}$ https://doi.org/10.1016/j.ecolecon.2014.09.016

Samek AS, Sheremeta RM. 2014. Recognizing contributors: An experiment on public good. Experimental Economics 17(4): 673-690. https://doi.org/10.1007/s10683-013-9389-1

Schouten G, Glasbergen P. 2011. Creating legitimacy in global private governance: The case of the roundtable on sustainable palm oil. Ecological Economics 70(11): 1891-1899. https://doi.org/10.1016/j.ecolecon.2011.03.012

Silva-Castaneda, L. 2012. A forest of evidence: Third-party certification and multiple forms of proof-a case study of oil palm plantation in Indonesia. Agricultural and Human Values 29(3): 361-370. https://doi.org/10.1007/s10460-012-9358-X

Steg L, Vlek C. 2009. Encouraging pro-environmental behavior: An integrative review and research agenda. Journal of Environmental Sustainability 29(3): 309-317. https://doi.org/10.1016/j.jenvp.2008.10.004

Steg L, Bolderdijk JW, Keizer K, Perlaviciute G. 2014. An integrated framework for encouraging pro-environmental behavior: The role of values, situational factors and goals. Journal of Environmental Psychology 38: 104-115. https://doi.org/10.1016/j.jenvp.2014.01.002

Stern PC, Kalof L, Dietz T, Guagnano GA. 1995. Values, beliefs, and pro environmental action: Attitude formation toward emergent attitude objects. Journal of Applied Social Psychology 25(18): 1611-1636. https://doi.org/10.1111/j.1559-1816.1995.tb02636.x

Tietenberg T, Lewis L. 2012. Environmental and natural resource economics. Pearson Education Inc, Boston, United States of America.

UNDP. 2014. Project document: sustainable palm oil initiative, country project: Indonesia. Accessed on 22.05.2017. Available at: https://info.undp.org/docs/pdc/Documents/ IDN/82941\%20SPO\%20PRODOC.pdf.

Villamor GB, Desrianti F, Akiefnawati R, Amaruzaman S, Van Noordwijk M. 2014. Gender influences decisions to change land use practices in the tropical forest margins of Jambi, Indonesia. Mitigation and Adaptation Strategies for Global Change 19(6): 733-755. https://doi.org/10.1007/s11027-013-9478-7

Vijay V, Pimm SL, Jenkins CN, Smith SJ. 2016. The impact of oil palm on recent deforestation and biodiversity loss. PloS One 11(7). https://doi.org/10.1371/journal.pone.0159668 
Von-Geibler, J. 2013. Market-based governance for sustainability in value chains: Conditions for successful standard setting in the palm oil sector. Journal of Cleaner Production 56: 39-53. https://doi.org/10.1016/i.jclepro.2012.08.027

Winkelmann, R. 2008. Econometric analysis of count data. Springer, Berlin, Germany.

Wilcove DS, Koh LP. 2010. Addressing the threats to biodiversity from oil-palm agriculture. Biodiversity and Conservation 19(4): 999-1007. https://doi.org/10.1007/s10531-0099760-X

Wunder S, Engel S, Pagiola S. 2008. Taking stock: A comparative analysis of payment for environmental services program in developed and developing countries. Ecological Economics 65(4): 834-852. https://doi.org/10.1016/j.ecolecon.2008.03.010

Zelezny LC, Chua PP, Aldrich C. 2000. New ways of thinking about environmentalism: Elaborating on gender differences in environmentalism. Journal of Social Issues 56(3): 443-457. https://doi.org/10.1111/0022-4537.00177 


\section{Appendix}

The Appendix consists of two parts. Part I presents explanations of the HL-task and its translation. Part II provides translations of the instructions for the social dilemma experiment.

\section{Part 1. Holt and Laury task}

Payoff matrix

Table II-A1. Payoff matrix of the HL-task

\begin{tabular}{|c|c|c|}
\hline Row & Option A & Option B \\
\hline 1 & $10 \%$ of 4,000IDR, 90\% of 3,200IDR & $10 \%$ of 7,600IDR, 90\% of 200IDR \\
\hline 2 & $20 \%$ of 4,000IDR, 80\% of 3,200IDR & $20 \%$ of 7,600IDR, 80\% of 200IDR \\
\hline 3 & $30 \%$ of 4,000IDR, 70\% of 3,200IDR & $30 \%$ of 7,600IDR, 70\% of 200IDR \\
\hline 4 & $40 \%$ of 4,000IDR, 60\% of 3,200IDR & $40 \%$ of 7,600IDR, 60\% of 200IDR \\
\hline 5 & $50 \%$ of 4,000IDR, 50\% of 3,200IDR & $50 \%$ of 7,600IDR, 50\% of 200IDR \\
\hline 6 & $60 \%$ of 4,000IDR, 40\% of 3,200IDR & $60 \%$ of 7,600IDR, $40 \%$ of 200IDR \\
\hline 7 & $70 \%$ of 4,000IDR, 30\% of 3,200IDR & $70 \%$ of 7,600IDR, 30\% of 200IDR \\
\hline 8 & $80 \%$ of 4,000IDR, 20\% of 3,200IDR & $80 \%$ of 7,600IDR, $20 \%$ of 200IDR \\
\hline 9 & $90 \%$ of 4,000IDR, $10 \%$ of 3,200IDR & $90 \%$ of 7,600IDR, $10 \%$ of 200IDR \\
\hline 10 & $100 \%$ of 4,000IDR, $0 \%$ of 3,200IDR & $100 \%$ of 7,600IDR, $0 \%$ of 200IDR \\
\hline
\end{tabular}

Translation of the questionnaire sheet for the Hl-task

"In the HL-task, there are ten paired series with different gains as pictured by the colouredballs. In every row, there are two bags: A and B. There are ten coloured balls inside of each bag. There are red and yellow balls in Bag A, green and blue balls in Bag B. The colour indicates monetary value: red is 4,000 IDR; yellow is 3,200 IDR; green is 7,600 IDR and blue is 200 IDR. Thus, in the row one, Bag A contains one red ball and nine yellow balls, while Bag B contains one green ball and nine blue balls, and so on until row ten, according to Table II-A2. In every row you can take one ball, and thus, you must choose to take the ball from bag A or B. Please write down your answer on the questionnaire sheet. At the end of this task, we provide a real monetary incentive, such as a shopping voucher. To determine the monetary incentives, there are two steps. Regarding that, we provided one additional bag containing ten coins numbered 1 to10. These ten coins represent the ten rows of the HL-task. The two steps are:

1. Please draw one coin. The number written in the coin indicates the number of the rows.

Example: You draw the coin numbered two, and in the second row, you chose bag A.

2. On that selected row, you will receive Bag A or Bag B, depending on your choice as written in the questionnaire sheet. 
Example: In the second row, you chose bag A, which inside are two red balls and eight yellow balls. You should take one ball blindly from the bag. If you take the red ball, then your shopping voucher is 4,000 IDR. If you take yellow ball, then your shopping voucher is 3,200 IDR."

Table II-A2. Holt and Laury task

\begin{tabular}{|c|c|c|}
\hline & Option (A or B) & \\
\hline & & \\
2 red balls, 8 yellow balls & & \\
\hline
\end{tabular}

Notes: due to page limitation, we only present the row 1 and 2 here

\section{Part 2. The experiment of social dilemma}

\section{General Instruction}

“Thank you for your participation in this task regarding oil palm plantations' expansion. This task consists of six rounds of individual decision making, where each round represents one year. Your decisions are confidential, and thus, you cannot discuss it with other participants. First, we will make three rounds. Second, you can take a short break, and we will give you additional instructions and explanations. Third, you participate in round four, five, and six. The more detail instructions and explanation are as follows:

1. You are a member of a group that consists of four people, including you. The composition of the members is the same until the sixth round. The members are confidential, and you must not discuss it with others.

2. Imagine that you own ten hectares of productive oil palm plantations. These plantations are located near rainforests and yield 15 tons of fresh fruit bunches (FFBs) per hectare per year. The price of FFBs per $\mathrm{kg}$ is 1,000 IDR. Thus, you earn 150 million IDR per year. This income is your "initial income." 
3. Every year, you can expand your plantations by cutting the forest up to ten hectares. Every member of your group can make this expansion. The expansion is resulting on:

3.1. Per hectare of expansion generates additional profit ( $p)$. The " $p$ " is five million IDR. Example:

You expand ten hectares and earn additional profit 10p, which equal to 50 million IDR.

3.2. Per hectare of your expansion reduces other members' income by $1 / 2 \mathrm{p}$. Same also applied if they also make expansion

Example:

You expand ten hectares. This expansion reduces the income of each member in your group by $10 \times 1 / 2 \mathrm{p}=25$ million IDR.

3.3. You can expand up to ten hectares, but if you decide to expand less than ten hectares, you will receive "return from the forest kept" for every hectare of forest kept. The value of the return from the forest kept is $1 / 2 \mathrm{p}$ per hectare.

\section{Example:}

You expand six hectares and earn an additional profit of $6 p=30$ million IDR, saving four hectares of forest. Thus, your "return from forest kept" is $=4 \times 1 / 2 p=10$ million IDR. The six hectares expansion reduces the income of each member in your group by $6 \times 1 / 2 p=15$ million IDR.

4. Calculation of annual income

Annual income $=$ initial income + additional profit from expansion + return from forest kept - loss from other members expansion

5. Writing down your decision

Write your decision on the questionnaire sheet. For expansion, circle option A and indicate the number of expansions. Circle option B for zero expansion. After each round, we will collect the questionnaire sheet to calculate the income and give it back to you."

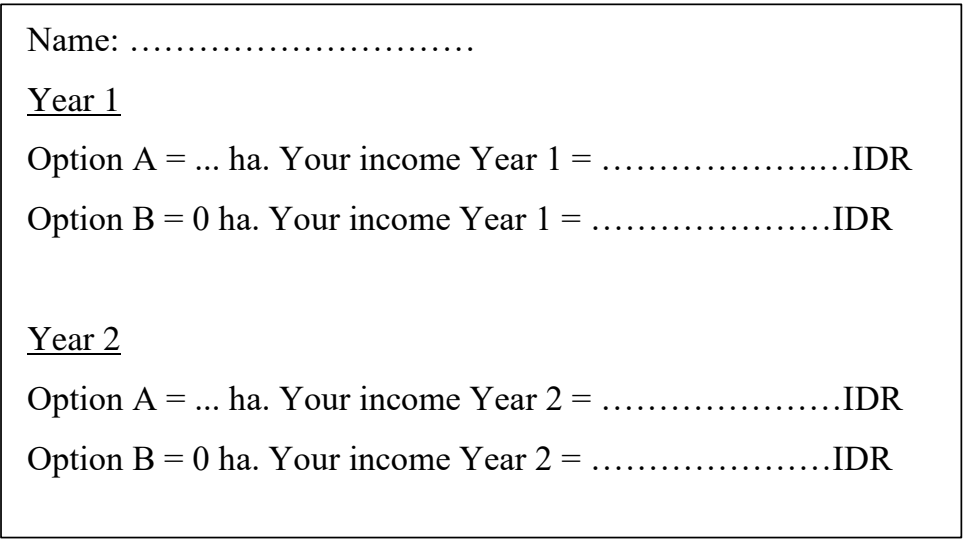

Figure II-A1. The page of the questionnaire for the social dilemma experiment 


\section{Short break}

\section{Instruction for the policies implementation}

Four types of instructions are:

1. Instructions for control villages:

"Now we would like to invite you to round four, five, and six. The rules remain the same."

2. Instructions for Policy 1 villages (Price premium):

"Initially, the price of FFBs per kg was 1,000 IDR. Before we proceed to the next round, we would like to inform that the price per kilogram FFBs is changed to 1,500 IDR for those who decide not to expand (choose option B). The other rules remain the same."

3. Instructions for Policy 2 villages (Environmental information):

"Before you continue, we will distribute maps of Jambi Province and its land-use. We have two maps: from the year 1990 and 2010. Dark green is primary forest, light green is secondary forest, purple indicates oil palm plantations. The circles help you to indicate these three purposes of the land-use. Thank you for your attention to this information. Now we would like to invite you to proceed to the next round. The rules remain the same."

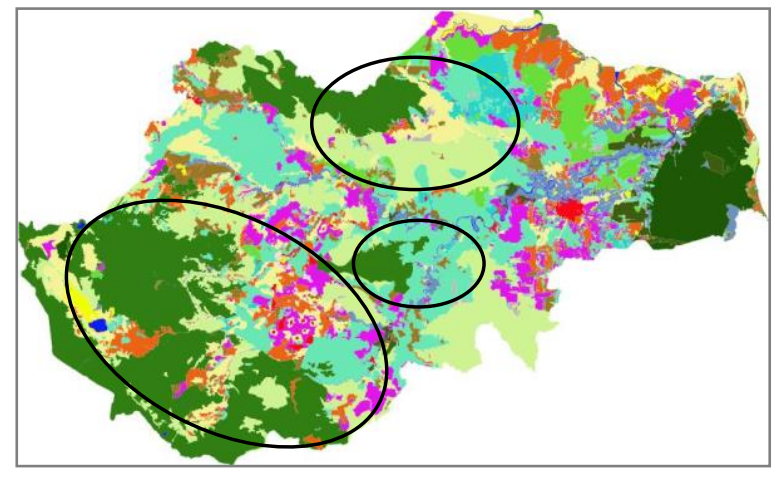

Figure II-A2. Jambi land use year 1990

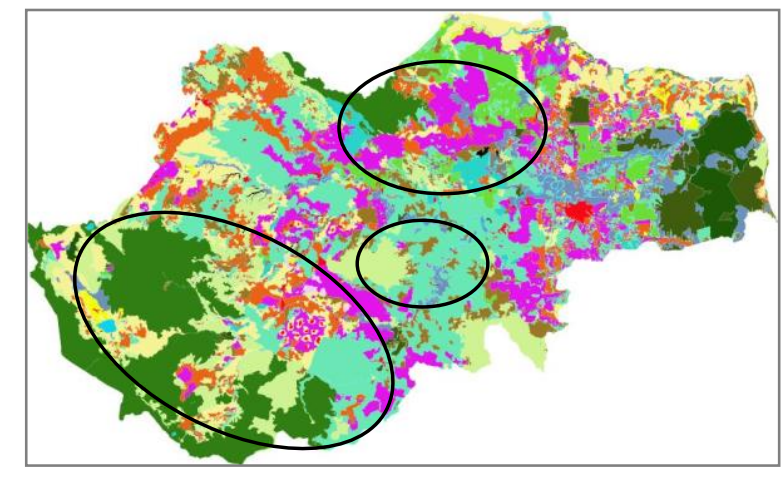

Figure II-A3. Jambi land use year 2010 Notes: Cartography = Dian Melati, Forest Inventory and Remote Sensing, University of Göttingen, Germany

4. Instructions for Policy 3 villages (Contributor Recognition):

"Thank you for your participation in the first three rounds of the experiment. In the first three rounds, the members of the groups are confidential. Now we would like to inform the members of the group. Although you know the members of your group, the experiment is still an individual task. You must not discuss with others. Now we would like to invite you to proceed to round four, five and six, where the rules remain same." 
In this task, the farmers receive a real monetary incentive, i.e., a shopping voucher. The real monetary incentives are determined in the following way:

1. We randomly selected one farmer per village.

2. We provided an additional bag with six numbered coins. These six coins represent the six rounds of the experiment. Afterward, the selected farmer randomly draws one coin. The coin indicated the selected round of the experiment.

\section{Example:}

"The payoff in the selected round is 175 million IDR, the selected person receives 175,000 IDR.” 


\title{
III. Are risk attitudes and time preferences crucial factors for crop-diversification by smallholder farmers?
}

Arieska Wening Sarwosri, Oliver Mußhoff

This paper has been published in:

Journal of International Development, 2020 Vol. 32 (922-942)

Original submitted May 2019, revision received September 2019, accepted April 2020

DOI: https://doi.org/10.1002/jid.3483

The earlier version of this paper has been published in:

EFForTS discussion paper series, May 2019, No. 28

\begin{abstract}
This study examines whether the decision of crop-diversification for perennial crops is based on risk attitudes and time preferences. We conducted incentivised field experiments with farmers who cultivates rubber and farmers who cultivates two crops (rubber and oil palm). We utilized Holt and Laury task and Coller and William task. We found that farmers who cultivate two crops were more risk-averse, indicating they see crop-diversification as a safer option for their farms. However, the discount rates of the two groups are not significantly different. These results provide relevant information for policy makers who intend to either encourage or discourage oil palm cultivation.
\end{abstract}

Keywords:

Crop-diversification, oil palms, perennial crops, risk attitudes, rubber, time preference

JEL Classifications: D13, Q12, Q15 


\section{Introduction}

Risk attitudes and time preferences are important for farmers' decision making (Falk et al., 2018). Farmers' risk attitudes influence adoption of high yield variety crops, drought-tolerant plants, new farming systems such as conservation agriculture, and decision to diversify crops (Feder, 1980; Hellerstein et al., 2013; Holden and Quiggin, 2017; Ngwira et al., 2013). Cropdiversification is a practice of cultivating two or more crops simultaneously to reduce income risks by creating several income sources.

However, the relationship between risk attitudes and crop-diversification is unclear. Studies by Chavas and Di Falco (2012) and Bezabih and Sarr (2012) involving Ethiopian farmers found that risk aversion increases the likelihood of crop-diversification. In contrast, a study by Hellerstein et al. (2013) involving the United States farmers found that more risk-averse farmers are less likely to diversify crops. The existing literature investigating farmers' risk attitudes and crop-diversification is also incomplete. To date, the literature only focuses on seasonal and/or annual crops (e.g., Bezabih and Sarr, 2012; Chavas and Di Falco, 2012; Dercon, 1996; Hellerstein et al., 2013). Thus, the literature leaves a gap for investigating crop-diversification of perennial crops. Perennial crops have different types of risks, for example, perennial crops are more susceptible to diseases because crop rotation and fallow periods cannot be conducted (Cox et al., 2005).

Furthermore, farmers' time preferences are quite pertinent, given that cultivating perennial crop have long-term consequences. Firstly, there is a long waiting time between planting and harvesting. Hence, farmers should have a plan for these zero-income period. Second, once the farmers cultivate a perennial crop, their income will depend on this crop for many years. Third, future is uncertain. For example, compares to seasonal/annual crop, the perennial crops have the possibility of suffering from future climate change (Lobell et al., 2006). However, despite the vital role of time consideration, it is also unclear how farmers' time preferences influence the crop-diversification of perennial crops.

To the best of our knowledge, the closest studies were conducted by Bocqueho and Jacquet (2010) and Ouattara et al. (2019) ${ }^{13}$. These studies investigate the relationship between farmers' risk attitudes and decision to diversify one annual and one perennial crop. They found that risk

\footnotetext{
${ }^{13}$ Bocqueho and Jacquet (2010) investigated farmers' decision to diversify between one type of annual crops (rape, wheat, or barley) and one type of perennial crop (switchgrass or miscanthus). Ouattara et al. (2019) investigated farmers' decision to diversify between one annual crop (corn) and one perennial crop (cashew nut).
} 
aversion hinders the diversification. Nevertheless, this study did not investigate farmers' time preferences. To fill this research gap, we measured risk attitudes and time preferences of farmers who cultivate one perennial crop and farmers who cultivated two perennial crops. The perennial crops are oil palm and rubber. Our study took place in Jambi Province, Sumatra, Indonesia.

Therefore, this study contributes to the literature body in two ways. First, this study investigates the relationship between farmers' risk attitudes and time preferences and cropdiversification of two perennial crops. Second, our study depicts the situation of cropdiversification in Asian context. So far, the studies took place in African countries (Bezabih and Sarr, 2012; Chavas and Di Falco, 2012; Dercon, 1996) or in high-income countries (Hellerstein et al., 2013). Involving Indonesian farmers provides a unique feature of sample, because they are somehow different to the western farmers, who mostly cultivate various seasonal/annual crops simultaneously.

The structure of this is as followed. Section 2 presents the hypotheses. Section 3 presents the HL-task (Holt and Laury, 2002) and CW-task (Coller and Williams, 1999), the estimation method, and the sample selection. Section 4 presents descriptive statistics, results, and discussions. Section 5 presents the conclusions and policy recommendation.

\section{Derivation of hypotheses}

Our study took place in Jambi Province. There, oil palm and rubber are two most important perennial crops. Initially, Jambi Province focused on focused on rubber production until around the year 1990s. In that period, the government introduced oil palm cultivation through the transmigration program (Feintrenie and Levang, 2009). This study involves two groups of farmers: (1) rubber farmers; (2) farmers who cultivates rubber and oil palms, as so-called "double-crop farmers." We will compare the risk attitudes and time preferences of the two groups but first we formulate two hypotheses, which based on a literature review and a secondary dataset.

\subsection{Risk attitudes of the farmers and crop choice}

The weather is an important risk factor in agriculture, for example, drought and extreme weather substantially diminish farmers' incomes (Lien and Hardaker, 2001; Turvey and Kong, 2010). The weather influences rubber production in two ways. First, rubber yields depend on precipitation. Latex is taken daily (mostly morning). To harvest latex, the farmers remove the tree bark and let the latex flows inside of a collecting cup. In the afternoon or in the following 
day, the farmers collected the latex in a bigger container. Rainwater can reduce the yield by overflowing the latex from the collecting cups (Feintrenie et al., 2010). Second, low humidity causes lower production (Miyamoto, 2006). While in contrast, oil palm trees are less affected by the weather, and the yields are relatively identical in whole year (Rist et al., 2010).

Price fluctuations are other important risk factor in agriculture (Aimin, 2010). To observe the price fluctuation of both crops, we use a weekly price dataset for the years 2013 to $2015^{14}$. The percentage change of price is illustrated in Figure III-1. Visually, we can see that the price of oil palm fruits is more fluctuated than rubber. In addition to Figure III-1, we calculated the price volatility (following the calculation from Gilbert and Morgan, 2010). The price volatility of rubber is $15.76 \%$, and oil palm fruits is $21.28 \%$.

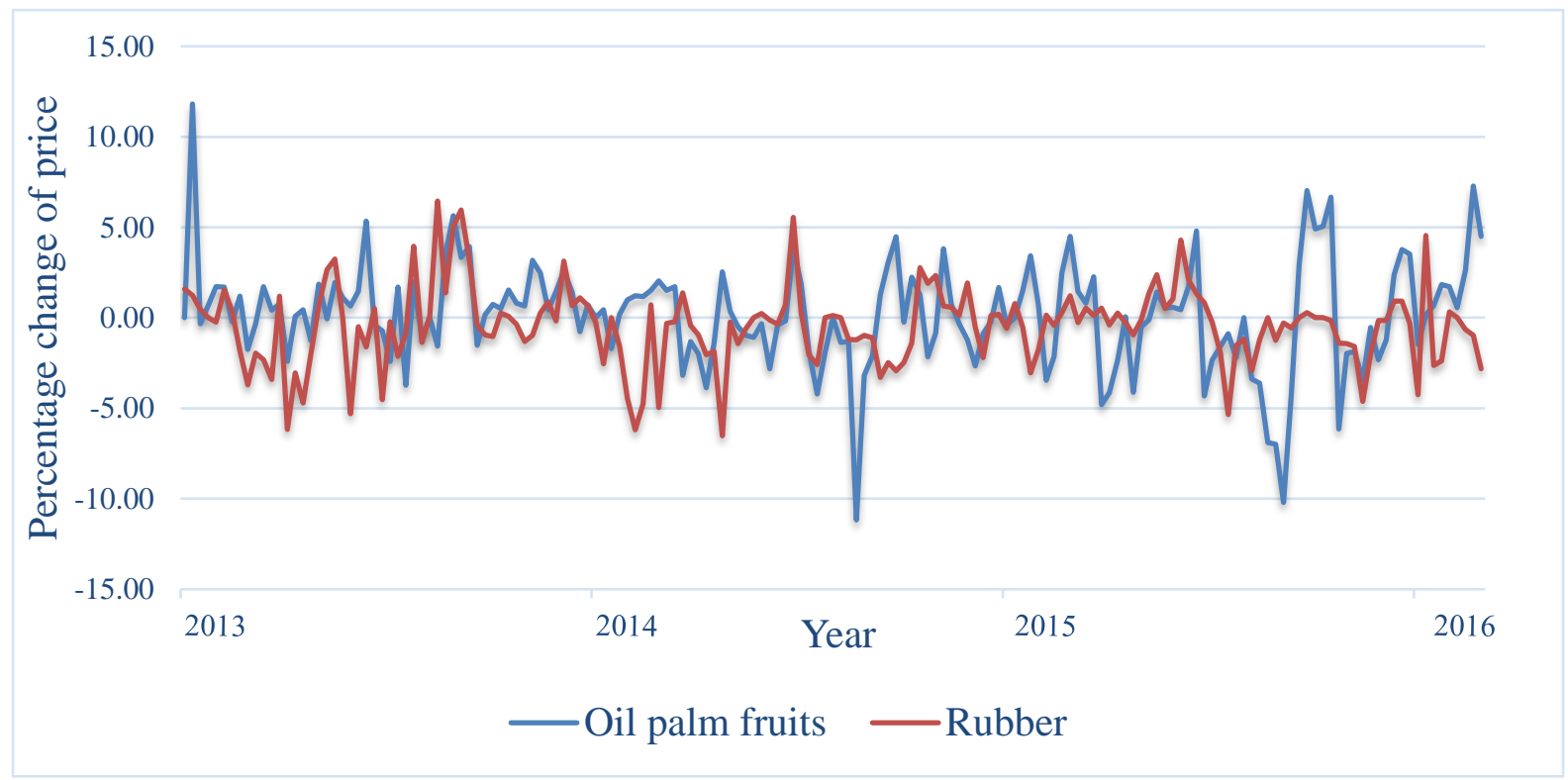

Figure III-1. Percentage changes of price for oil palm fruits and rubber at farm gate Notes: Those are weekly price; $\mathrm{N}=165$; the source for the price of oil palm fruits was from weekly meeting of the Ministry of Agriculture at the province level; the source for the price of rubber was from GAPKINDO - the Rubber Association of Indonesia

From the two risk factors, we observe that rubber and oil palm trees face different types of risk. Rubber yield strongly depends on weather, while price of oil palm fruits is more volatile. To formulate the hypothesis, we refer to the portfolio concept by Markowitz (1952). This

\footnotetext{
${ }^{14}$ The price of oil palm fruits at the farm-gate was determined by a weekly meeting of the Ministry of Agriculture at the province level, private companies, and farmer groups (Hidayat et al., 2015). We obtained the price of oil palm fruits from the weekly meeting transcript. The price of oil palm fruits differs depending on the trees' age, and thus, we used the average price of oil palm fruits from different ages of trees. The rubber price was assigned daily, depending on the world price (Feintrenie and Levang, 2009; Marimin et al., 2014). We obtained the daily price of rubber from GAPKINDO. To make the price of both crops comparable, we used the Thursday price of rubber because the price of oil palm fruits was determined every Thursday.
} 
portfolio concept explain that every investment has expected return and variances, and hence, diversifying investments can be a solution to reduce investment variances. Indeed, the diversification could not eliminate all potential investments variances, but it helps to maximize the expected returns with minimum variances (Markowitz, 1952). In this regard, the correlation coefficients of the expected returns from both investments should be less than one (ideally negative). In agriculture, the portfolio concept is implemented by cultivating two or more crops, i.e., crop-diversification (Dercon, 1996; Heady, 1952; Pellegrini and Tasciotti, 2014).

Based on the information of the price (cf. Figure III-1), farmers' productivities ${ }^{15}$, and plantation areas, we could estimate the expected weekly returns of both crops. The correlation coefficient of the expected returns is 0.31 , which is less than one. This indicates that cropdiversifications can be taken to maximize the expected returns with minimum variances. Therefore, risk-averse farmers have an incentive to cultivate rubber and oil palms together. Accordingly, the first hypothesis is formulated as:

\section{H1. More risk-averse farmers cultivate oil palms besides rubber.}

\subsection{Time preferences of the farmers and crop choice}

Compared to rubber, oil palm tree has a shorter waiting period between planting and first harvest. The first harvest of oil palm starts in the fourth year and the trees are productive up to 25 years (Corley and Tinker, 2016). The first harvest of rubber is in the seventh years and the trees are productive up to 30 to 35 years (Woittiez et al., 2017). Thus, oil palm tree has a shorter waiting period for the first harvest, but rubber tree has longer productive years. Literature also mentions that the annual expected returns per land of rubber is higher, and thus, a full productive period of rubber tree provide higher returns than oil palm (Feintrenie et al. 2010).

Individuals with high discount rates prefer to receive an early payoff even if it is smaller than a later payoff (Coller and Williams, 1999). Farmers are characterized as individuals with high discount rates (Lawrance, 1991). This implies that they potentially prefer to cultivate a crop that give earlier income than crop with higher expected returns but longer waiting period. Hence, rubber farmers with a higher discount rate may prefer to cultivate oil palms than expand their existing rubber plantations. Therefore, the second hypothesis could be formulated as:

H2. Farmers with higher discount rates cultivate oil palms besides rubber.

\footnotetext{
${ }^{15}$ To obtain information about the productivities, we refer to the annual reports (2012-2015) from the Ministry of Agriculture.
} 


\section{Methodology}

The study involved 636 Indonesian farmers including two groups of farmers: (1) farmers who cultivated only rubber, (2) farmers who cultivated rubber and oil palm trees. We estimated the risk attitudes and time preferences experimentally. The HL-task was used to observe the risk attitudes, and a CW-task was conducted to determine the time preferences by estimating individual discount rates. The HL-task and CW-task have been used in several studies involving rural people and farmers (Holden and Quiggin, 2017; Ihli et al., 2016; Tanaka et al., 2010). Both tasks were incentivised, i.e., payments were given for each task, to encourage sensible and realistic decisions making by the participants during the experiments (Hertwig and Ortman, 2001). To estimate the farmers' risk attitudes and discount rates, we applied the jointestimation-method by Andersen et al. (2008). In this joint-estimation, risk attitudes and discount rates were estimated simultaneously. To check the robustness of the results, we also included farmers' socioeconomic and demographic information in the calculation.

\subsection{Research area and sample selection}

The research was conducted in Jambi Province. In Jambi, two most important perennial crops are oil palm and rubber. Initially, rubber was cultivated using the "rubber-agroforest" farming practice. In this farming practice, rubber trees are planted together with other cash and non-cash crops, imitating the rich diversity of plants in forest areas (Rembold et al., 2017). Other crops are mostly a quick-developing plant such as upland rice, vegetables, and fruits (Feintrenie and Levang, 2009). These plants provide a safety net of income before the farmers could obtain yields from rubber. By the end of the $20^{\text {th }}$ century, gradually, rubber monocultures were established (Feintrenie et al., 2010). The oil palm cultivation came later together with the transmigration program around the year 1990s (Feintrenie et al., 2010; Gatto et al., 2015).

Jambi is located on the east coast of central Sumatra, Indonesia. Jambi covers the area of about five million hectares that consists of highlands (conserved) and lowland rainforest (largely transformed to agricultural lands) (Clough et al., 2016). In 2013, around 50\% of Jambi's lands were agricultural land, and more than half of the population worked in the agricultural sector (Clough et al., 2016; Drescher et al., 2016). Our research took place in the lowland areas, including Batanghari, Bungo, Muaro Jambi, Sarolangun, and Tebo regency. These five regencies constituted the largest parts of lowland farming areas in Jambi Province where rubber and oil palm are cultivated (Krishna et al., 2017). Our study conducted in 45 villages consisted of: eight villages per regency that were selected randomly and five additional 
villages (selected purposively) to support the ongoing research project (see Clough et al., 2016; Kubitza et al., 2018; Krishna et al., 2017). Figure III-2 presents the map of Jambi Province and the spatial distribution of the research villages.

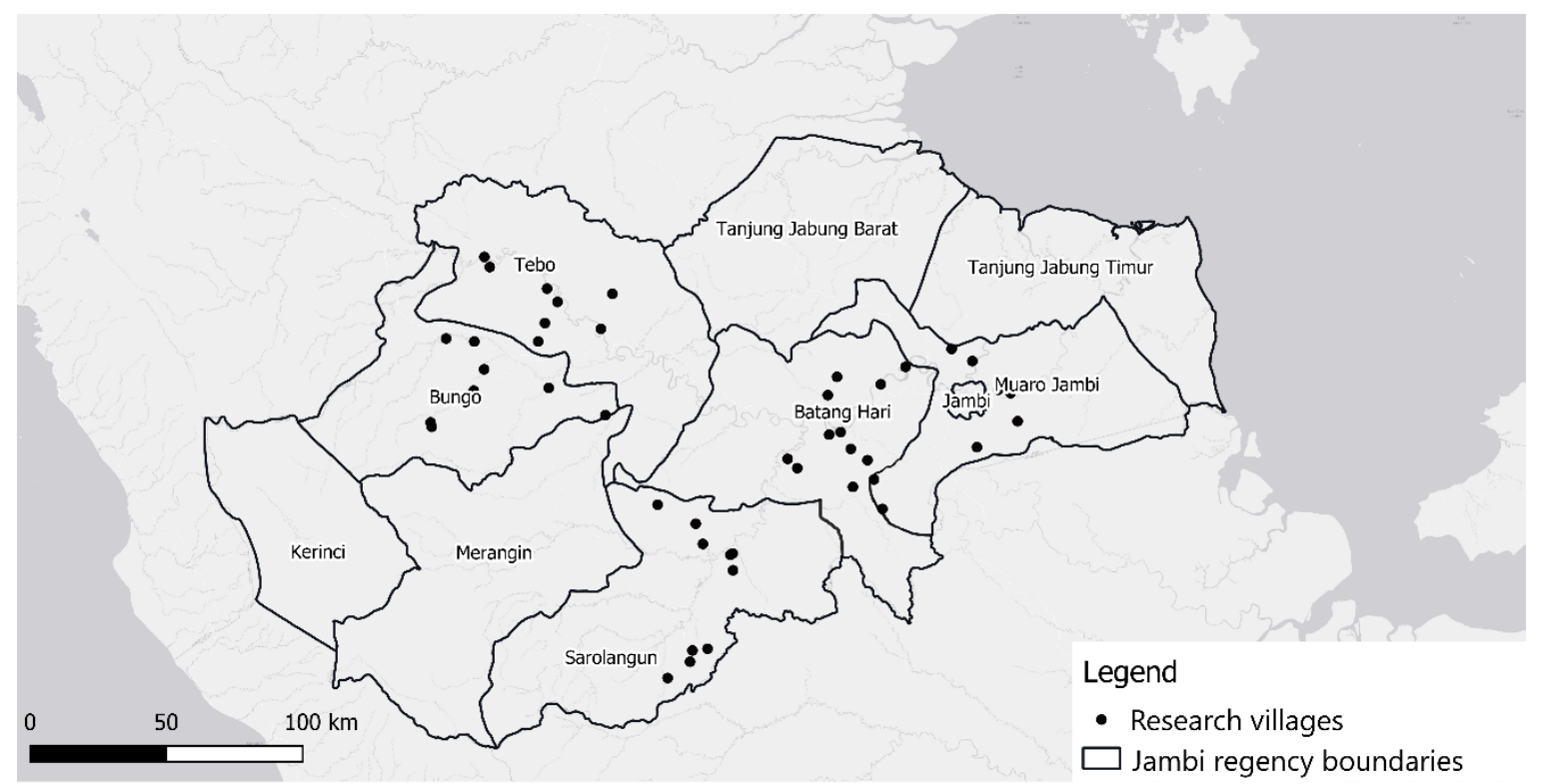

Figure III-2. Map of Jambi Province indicating the research villages

Notes: Cartography $=$ Christoph Kubitza, Department of Agricultural Economic and Rural Development, University of Göttingen

The number of observations per village varied depending on the farmers population. The farmers were selected randomly from the farmers list, which we got from the village heads or leaders of farmer-groups. We included rubber farmers $(\mathrm{N}=437$ farmers $)$ and double-crop farmers ( $N=199$ farmers). The farmers were the household heads, who were commonly the families' decision-makers. We also obtained socioeconomic and demographic information of the households. The study took place from October 2016 until January 2017.

\subsection{HL-task}

The incentivised HL-task was used to elicit farmers' risk attitudes. Using the Multiple Price List (MPL), the farmers were confronted with a series of ten paired lotteries. Within these ten paired lotteries, the chances of obtaining a high payoff were gradually increase as presented in Table III-1. Each paired lottery consists of two options: option $A$ and option $B$, and there were two payoffs in each option: a high and a low payoff. The two payoffs in option $A$ were 4,000 Indonesian Rupiah (IDR) and 3,200 IDR, and the payoffs in option $B$ were 7,600 IDR and 200 IDR $^{16}$. The difference between the high and low payoff in option $A$ was less than in option $B$.

${ }^{16} 1 \$ \approx 13,440 \mathrm{IDR}$. 
Thus, option $A$ was a safe-option, and option $B$ was a risky-option. In each row, the farmers must make one choice, choosing option $A$ or $B$. The row where the farmers switched from option $A$ to option $B$ implied the respective their risk attitudes.

Table III-1. Multiple price list of the HL-task of rubber and double-crop farmers

\begin{tabular}{|c|c|c|c|c|}
\hline Row & Option $A$ & Choice & Option $B$ & $\begin{array}{c}\text { Expected payoff } \\
\text { difference }\end{array}$ \\
\hline 1 & $10 \%$ of $4,000,90 \%$ of 3,200 & $\ldots$ & $10 \%$ of $7,600,90 \%$ of 200 & 2,340 \\
\hline 2 & $20 \%$ of $4,000,80 \%$ of 3,200 & $\ldots$ & $20 \%$ of $7,600,80 \%$ of 200 & 1,680 \\
\hline 3 & $30 \%$ of $4,000,70 \%$ of 3,200 & $\ldots$ & $30 \%$ of $7,600,70 \%$ of 200 & 1,020 \\
\hline 4 & $40 \%$ of $4,000,60 \%$ of 3,200 & $\ldots$ & $40 \%$ of $7,600,60 \%$ of 200 & 360 \\
\hline 5 & $50 \%$ of $4,000,50 \%$ of 3,200 & $\ldots$ & $50 \%$ of $7,600,50 \%$ of 200 & -300 \\
\hline 6 & $60 \%$ of $4,000,40 \%$ of 3,200 & $\ldots$ & $60 \%$ of $7,600,40 \%$ of 200 & -960 \\
\hline 7 & $70 \%$ of $4,000,30 \%$ of 3,200 & $\ldots$ & $70 \%$ of $7,600,30 \%$ of 200 & $-1,620$ \\
\hline 8 & $80 \%$ of $4,000,20 \%$ of 3,200 & $\ldots$ & $80 \%$ of $7,600,20 \%$ of 200 & $-2,280$ \\
\hline 9 & $90 \%$ of $4,000,10 \%$ of 3,200 & $\ldots$ & $90 \%$ of $7,600,10 \%$ of 200 & 2,940 \\
\hline 10 & $100 \%$ of $4,000,0 \%$ of 3,200 & $\ldots$ & $100 \%$ of $7,600,0 \%$ of 200 & $-3,600$ \\
\hline
\end{tabular}

Notes: The amount of payoff was in IDR

In our study, the HL-task was visualised following Ihli et al. (2016). The payoffs were depicted in images of a coloured ball inside of a closed bag. Red and yellow represented the high and low payoffs in option $A$, while green and blue visualised high and low payoffs in option $B$. The proportions of coloured balls changed according to the probabilities. For example, in row 1, inside of the bag A was one red ball and nine yellow balls, while bag B had one green ball and nine blue balls. In row 2, bag A contained two red and eight yellow balls, while bag B contained two green and eight blue balls; and so on until row ten (see Table III-A1 Appendix).

One may wonder whether using the coloured images has a potential problem of colour bias. Colour bias occurs when decision makers' colour preferences associates with their socioeconomic and demographic background, such as gender (e.g., Ellis and Ficek, 2001; Hurlbert and Ling, 2007). Nevertheless, the coloured images were meant to help farmers understanding the HL-task better as argued by Ihli et al. (2016). Hence, we avoided potential misunderstanding of written task for illiterate and low-educated farmers, which were common in developing countries (Nielsen et al., 2013). The misunderstanding lead to inconsistency and potentially lowered the measurement' reliability (Ihli et al., 2016). We also explained that one colour depicts a certain amount of money; the red ball is 4,000 IDR, yellow is 3,200 IDR, green is 7,600 IDR, and blue is 200 IDR. Emphasizing the value of each colour should ease favouritism of a specific colour.

To check the colour bias in our observation, we analysed the relationships between farmers' background and selections of the two options in the HL-task. The relationship was depicted as 
a correlation coefficient ( $\rho$ ) as in Table III-A2 (Appendix). The values of the $\rho$ were remarkably close to zero with positive or negative signs, indicating weak relationships ${ }^{17}$. Therefore, we are confident that farmers' choices in the HL-task based on their risk preferences instead of colour preferences. Even if a slight colour bias presented; we expected that the colour bias applies for all farmers from both groups (rubber and double-crop farmers). Since the colour bias should be the same for both groups, then, the case of colour bias was not critical for group comparison.

\section{3. $C W$-task}

We used an incentivised CW-task to measure time preferences following Coller and Williams (1999) with two options of payoffs: (1) option I, earlier-smaller payoff; (2) option II, laterhigher payoff. The matrix payoffs of the CW-task are presented in Table III-2.

Table III-2. Payoff matrix of the CW- task of rubber and double-crop farmers

\begin{tabular}{|c|c|c|c|}
\hline Row & Option I (in seven days) & Choice & Option II (in 90 days) \\
\hline 1 & 50,000 & $\ldots$ & 51,300 \\
\hline 2 & 50,000 & $\ldots$ & 52,500 \\
\hline 3 & 50,000 & $\ldots$ & 53,800 \\
\hline 4 & 50,000 & $\ldots$ & 55,200 \\
\hline 5 & 50,000 & $\ldots$ & 56,500 \\
\hline 6 & 50,000 & $\ldots$ & 57,900 \\
\hline 7 & 50,000 & $\ldots$ & 59,300 \\
\hline 8 & 50,000 & $\ldots$ & 60,700 \\
\hline 9 & 50,000 & $\ldots$ & 62,000 \\
\hline 10 & 50,000 & & 63,600 \\
\hline
\end{tabular}

Notes: The amount of payoff was in IDR

We modified some specific elements to provide a feasible design of the task. In our design, option $I$ was a payoff in a week (seven days) and the payoff value was fixed at 50,000 IDR ${ }^{18}$. We applied front delay in option $I$ to avoid a present bias and to reduce temptation of getting a “today" gain (Andersen et al., 2008). The front delay also held constant transaction cost, i.e.,

\footnotetext{
${ }^{17}$ We conducted a t-test to examine whether the $\rho$ are statistically significantly different from zero. For the rubber farmers, the variable age and loan are significant at the 5\% level. For the double-crop farmers, the variable car ownership and plantation area are significant at the 5\% level. However, in a large sample size such as in our dataset, a small value for $\rho$ could be significantly different from zero at any level and hence, the significance has little practical importance for interpretations for the t-test (Taylor, 1990). Accordingly, Taylor (1990) suggested the use of the following categories of $\rho$ : where $\rho \leq 0.35$ indicates weak relationship, $0.35 \leq \rho \leq 0.67$ indicates a moderate relationship, $0.68 \leq \rho \leq 0.90$ indicates a strong relationship, and $>0.9$ indicates a very strong relationship. Otherwise, a further step could be to calculate the coefficient of determination $\left(\rho^{2}\right)$ by squaring the $\rho$ (Taylor, 1990). The $\rho^{2}$ indicates the percentage of farmers' choice for option $A$ or $B$ in the HL-task that could be explained by the socioeconomic and demographic variables. For example, the $\rho$ of the variable age for rubber farmers was 0.12 , and hence the $\rho^{2}$ was 0.01 , this means that only $1 \%$ of the total variation in the choice of option $A$ or $B$ could be explained by age, even though the variable was statistically significant.
}

${ }^{18}$ Daily wage of labour working in the rural area of Jambi Province was, on average, 50,000 IDR. 
uncertainty of future payments (Laury et al., 2012). Option II was a payoff in three months (90 days), which also used in previous literature (e.g., Hermann and Mußhoff, 2016; Laury et al., 2012). The values of payoffs increased along the ten rows of the matrix payoff based on the annual interest rates. The interest rates ranged from $10 \%$ to $100 \%$. In every row, the participants must make a choice (option $I$ or $I I$ ), where the ranges of discount rate were determined on the first switching point from option $I$ to $I I$.

\subsection{Monetary incentives}

For both tasks, the monetary incentives were shopping vouchers for daily groceries that could be used in a local shop ${ }^{19}$. Two steps to determine the HL-task payment were:

(1) Farmer randomly take one of ten numbered coins from a closed bag. The number indicates the row in the HL-task.

(2) On this row, the farmer blindly drew one ball from bag A or bag B depending on his/her choice as written in the questionnaire sheet. The value of the payment depicted by the ball colour. For example, if the red ball is taken, then the shopping voucher is 4,000 IDR.

To determine the value of the payments in the CW-task, the farmers randomly took one of ten numbered-coins from a closed bag. The number defined the row of the payments. For example, the famer drew coin number 5 . If his/her choice option $I$, then he/she received a shopping voucher 50,000 IDR that could be used on the seventh day after the experiment. If his/her choice was option II, then he/she receives 56,500 IDR that can be used on the ninetieth day after the experiments ${ }^{20}$.

\subsection{Joint-estimation-method}

Following Andersen et al. (2008), we utilised the joint-estimation method to estimate risk attitudes and time preferences simultaneously. To do so, Andersen et al. (2008) use the maximum likelihood and assume a power risk-utility function with constant-relative-risk-aversion (CRRA) (Holt and Laury, 2002):

$U(X)=\frac{(X)^{1-\theta}}{1-\theta}$

\footnotetext{
${ }^{19}$ We avoided giving cash incentives because it might be associated with bribing. Moreover, in some villages, the data collection also occurred nearly simultaneously with local leader elections, where it could be crucial if the farmers would think that we bought votes for a specific politician.

${ }^{20}$ The valid date of the shopping voucher was written to prevent the use before the set date.
} 
Where $U$ is the utility, $X$ are the payoffs in the HL-task, $\theta$ is the risk aversion coefficient ${ }^{21}$. If $j$ indicates the row in the HL-task, then let the high payoff is denoted as $h$ with the respective probability $p_{j}$, and the low payoff as $l$ with the respective probability as $1-p_{j}$. Thus, $X_{A h}$ indicates the high payoff and $X_{A l}$ indicated the low payoff of option A. $X_{B h}$ indicates high payoff and $X_{B l}$ indicates low payoff of option B. Then the expected utility $(E U)$ of the paired lotteries for option $A$ and $B$ of the HL-task is formulated as (Andersen et al., 2008):

$E U_{A j}=p_{j} \cdot U\left(X_{A h}\right)+\left(1-p_{j}\right) \cdot U\left(X_{A l}\right)$

and

$E U_{B j}=p_{j} \cdot U\left(X_{B h}\right)+\left(1-p_{j}\right) \cdot U\left(X_{B l}\right)$

To allow for randomness, Holt and Laury (2002) introduced a noise parameter $(\mu)$, the so-called Luce's error (Luce, 1959). If the probability of choosing option $A$ or $B$ in row $j$ is denoted as $P r_{j}^{H L}$. Hence, the probability of choosing option $A$ is (Holt and Laury, 2002):

$$
P r_{j}^{H L}(A)=\frac{E U_{A}^{\frac{1}{\mu}}}{E U_{A}^{\frac{1}{\mu}}+E U_{B}^{\frac{1}{\mu}}}
$$

The probability of choosing option $B$ is analogue to equation (4). If the decision to select one option is denoted as $y_{j}$, where $y_{j}=A$ if the participants chose option $A$ and $y_{j}=B$ for the choice of option $B$. Then, the log-likelihood of the HL-task $\left(L^{H L}\right)$ is (Andersen et al., 2008):

$\ln L^{H L}(\theta, \mu ; y, Z)=\sum_{j}\left(\left(\ln \left(P r_{j}^{H L}(A) \mid y_{j}=A\right)\right)+\left(\ln \left(1-P r_{j}^{H L}(A)\right) \mid y_{j}=B\right)\right)$

The vector of the household characteristics was denoted as $Z$. The estimation of the risk attitudes involving household characteristics was carried out for robustness check.

Furthermore, when the risk attitudes coefficients are involved in the estimation of the discount rates, the present value of the payoffs in the CW-task:

$P V_{I}=\left(\frac{1}{1+\delta}\right)^{t} \cdot \frac{\left(M_{I}\right)^{1-\theta}}{1-\theta}$

and

\footnotetext{
${ }^{21}$ Previous literature includes background consumption $(\omega)$ to define the utility (e.g., Sauter and Mußhoff, 2018). We assumed $\omega$ was equal to zero as in Andersen et al. (2008). Therefore, we do not consider $\omega$ in equation (1) and further equations.
} 
$P V_{I I}=\left(\frac{1}{1+\delta}\right)^{t+\tau} \cdot \frac{\left(M_{I I}\right)^{1-\theta}}{1-\theta}$

$P V_{I}$ is the present value of option $I$ and $P V_{I I}$ is the present value of the option $I I . M_{I}$ is the payoff of option $I$ in time $t=7$ days. $M_{I I}$ is the payoff of option $I I$, in time $t+\tau=90$ days. Thus, $\tau$ is the different between the early and later payoffs, i.e., 83 days. $\delta$ indicates the discount rate and $\vartheta$ is its noise parameter. If the probability of choosing option $I$ or $I I$ in the row $k$ of $C W$ task is denoted as $\operatorname{Pr}_{k}^{C W}$, then the probability of choosing the option $I$ could be defined as (Andersen et al., 2008):

$P r_{k}^{C W}(I)=\frac{P V_{I}^{\frac{1}{\vartheta}}}{P V_{I}^{\frac{1}{\vartheta}}+P V_{I I}^{\frac{1}{\vartheta}}}$

Let us denote the choice as $y_{k}$, where $y_{k}=I$ if the participants chose option $I$ and $y_{k}=I I$ for the choice of option $I I$. With the involvement of risk attitudes coefficient, the log-likelihood of the discount rates is formulated as:

$\ln L^{C W}(\theta, \delta, \mu, \vartheta ; y, Z)=\sum_{k}\left(\left(\ln \left(\operatorname{Pr}_{k}^{C W}(I) \mid y_{k}=I\right)\right)+\left(\ln \left(1-\operatorname{Pr}_{k}^{C W}(I)\right) \mid y_{k}=I I\right)\right)$

Similar to the estimation of risk attitudes, we included the household characteristics for the robustness check of the estimation.

\section{Descriptive statistics and results}

\subsection{Descriptive statistics}

To test the differences between the two groups of farmers, we used two tests: The Chi-square test for the variables with binary responses (1/0) and the Mann-Whitney $\mathrm{U}$ test for the variables with continuous values. The results of the tests and the descriptive statistics are presented in Table III-3.

The two groups of farmers have more male than females, but the Chi-square test shows that more males are double-crop farmers. 17\% of double-crop farmers have a car, and $6 \%$ of them also owned a truck. Around $6 \%$ of rubber farmers have a car, and almost none of them owned a truck. The variable "land title" indicates an official land title. There are two types of land title in Jambi: (1) official; (2) sporadic or informal. The sporadic land title is recognised by the local government but cannot be used for formal transactions such as collateral (Krishna et al., 2017). 
Our data show that the share of farmers holding official land titles is higher among the doublecrop farmers. Double-crop farmers used more services from lending and saving institutions (e.g., microcredit and savings).

The Mann-Whitney U test shows that double-crop farmers are significantly older. The rubber plantations owned by the double-crop farmers are older and larger ${ }^{22}$. The productive plantation areas are also larger. The farmers have on average two motorbikes, but the double-crop farmers have more motorbike than rubber farmers.

Table III-3. Descriptive statistics of rubber and double-crop farmers

\begin{tabular}{|c|c|c|c|c|}
\hline \multirow[b]{2}{*}{ Variables (units) } & \multirow[b]{2}{*}{ Variables' explanations } & \multicolumn{2}{|c|}{ Mean (st. dev.) / share in $\%$} & \multirow[b]{2}{*}{ p-values ${ }^{a}$} \\
\hline & & Rubber farmers & $\begin{array}{l}\text { Double-crop } \\
\text { farmers }\end{array}$ & \\
\hline Age (years) & Age of farmers & $45.85(10.21)$ & $47.94(10.31)$ & $0.01 * *$ \\
\hline Car $(1 / 0)$ & $=1$, if own cars & $6.17 \%$ & $17.09 \%$ & $0.00 * * *$ \\
\hline Gender $(1 / 0)$ & $=1$, if male & $95.88 \%$ & $98.49 \%$ & $0.09 *$ \\
\hline Land title $(1 / 0)$ & $=1$, if official title & $26.32 \%$ & $37.19 \%$ & $0.01 * *$ \\
\hline Loan $(1 / 0)$ & $=1$, if own loan & $44.62 \%$ & $56.78 \%$ & $0.00 * * *$ \\
\hline Motorbike & Number of motorbikes & $1.86(0.82)$ & $2.19(1.03)$ & $0.00 * * *$ \\
\hline Plantation age e $^{b}$ years) & Age of plantations & $18.07(9.42)$ & $\begin{array}{l}\text { Rubber } 20.04(9.31) \\
\text { Oil palm } 7.56(5.83)\end{array}$ & $0.01 * *$ \\
\hline Plantation $\operatorname{area}^{b}(\mathrm{ha})$ & Size of plantation areas & $2.98(3.23)$ & $\begin{array}{c}\text { Rubber } 3.89(4.94) \\
\text { Oil palm } 2.83(3.15)\end{array}$ & $0.01 * *$ \\
\hline Productive area (ha) ${ }^{b}$ & $\begin{array}{l}\text { Size of productive plantation } \\
\text { areas }\end{array}$ & $2.39(2.49)$ & $\begin{array}{c}\text { Rubber 3.19(3.92) } \\
\text { Oil-palm 1.93(3.19) }\end{array}$ & $0.01 * *$ \\
\hline Saving (1/0) & $=1$, if own saving & $23.34 \%$ & $43.72 \%$ & $0.00 * * *$ \\
\hline Truck (1/0) & $=1$, if own trucks & $0.46 \%$ & $3.52 \%$ & $0.00 * * *$ \\
\hline
\end{tabular}

Notes: $\mathrm{N}=636$ that consists of 437 rubber farmers, 199 double-crop farmers; ${ }^{a}$ Significance levels: $* * *$ at $1 \%$ level, ${ }^{* *}$ at $5 \%$ level, ${ }^{*}$ at $10 \%$ level; ${ }^{b}$ On the variable plantation age, plantation area and productive plantation area; the tests were carried out to compare the rubber plantations owned by rubber farmers and rubber plantations owned by double-crop farmers

\subsection{Results: Hypothesis 1}

To test the hypotheses, we estimated the risk attitudes and discount rate based on equations (5) and (9), respectively, using two models. In these two models, the farmers' socioeconomic and demographic were not included in the estimation.

Model 1 performs the joint-estimation to estimate the risk aversion coefficient $(\theta)$ and discount rate $(\delta)$ of both groups separately. Thus, at first, we estimate the risk attitudes and

\footnotetext{
22 The Mann-Whitney U test for testing the variables of plantation age, plantation area, and productive plantation area, is used to compare the rubber plantations owned by rubber farmers and the rubber plantations owned by double-crop farmers. The double-crop farmers own oil palm plantations, but the rubber farmers do not own oil palm plantations. Thus, it was not necessary to conduct the Mann Mann-Whitney U test for variables plantation age, area, and productive area of oil palm plantations.
} 
discount rates of rubber farmers. Secondly, we estimate the risk attitudes and discount rates of double-crop farmers. As $\theta$ and $\delta$ of both groups are estimated separately, we present the results in separate columns in Table III-4. Model 2 performs a joint-estimation using the observations of both groups together. In model 2, we create a dummy variable "double-crop farmer," where $1=$ double-crop farmers and $0=$ rubber farmers. The results of the estimation are presented in the last column of Table III-4.

Table III-4. Risk aversion coefficients and discount rates of farmers

\begin{tabular}{|c|c|c|c|}
\hline \multirow{2}{*}{ Parameters } & \multicolumn{2}{|c|}{ Model $1^{a}$} & \multirow{2}{*}{$\begin{array}{c}\text { Model } 2^{a} \\
\text { Coefficients }\end{array}$} \\
\hline & Coefficients & Coefficients & \\
\hline \multicolumn{4}{|c|}{ Panel A. Risk aversion coefficient $(\theta)$} \\
\hline Rubber farmers & 0.03 & - & 0.04 \\
\hline Double-crop farmers & - & $0.21 * * *$ & $0.13 * *$ \\
\hline \multicolumn{4}{|l|}{ Panel B. Discount rate $(\delta)$} \\
\hline Rubber farmers & $2.97 * * *$ & - & $2.74 * * *$ \\
\hline Double-crop farmers & - & $2.06 * * *$ & $2.56 * * *$ \\
\hline
\end{tabular}

Notes: $\mathrm{N}$ for rubber farmers $=8,740$ (number of clusters $=437$ ), $\mathrm{N}$ for double-crop farmers $=3,980$ (number of clusters $=199) ;{ }^{a}$ Significance levels: $* * *$ at $1 \%, * *$ at $5 \%$, $*$ at $10 \%$, the significance level indicates the difference between the values of $\theta$ and zero

Panel $A$ of Table III-4 shows the estimation of the risk aversion coefficient $(\theta)$. There are three categories to define the risk aversion (Holt and Laury, 2002): (1) $\theta$ is not statistically significantly different from zero, indicating risk-neutral individuals; (2) $\theta$ is negative and statistically significantly different from zero, indicating risk-loving individuals; (3) $\theta$ is positive and statistically significantly different from zero, indicating risk-averse individuals.

From model 1 , the estimated $\theta$ of rubber farmers is positive but not statistically significantly different from zero. This implied that, rubber farmers are risk-neutral individuals. The estimations of $\theta$ of double-crop farmers is positive and statistically significantly different from zero at a significant level of $1 \%$ and $5 \%$, respectively. These results indicate that the doublecrop farmers are risk-averse individuals. Model 2 shows the same findings. Thus, the results are robust as both models provide the same finding. Therefore, we could confirm our first hypothesis, which stated, "more risk-averse farmers cultivate oil palms besides rubber."

Monoculture practice for rubber and palm oil production have been associated with deforestation and biodiversity loss (Brandi et al., 2015; Wilcove and Koh, 2010). The monoculture practice also reduced land cover areas of rubber agroforest due to higher profits (Drescher et al., 2016; Grass et al., 2020). However, despite the importance of rubber in Jambi, the areas of rubber plantation are steady while the areas of oil palm monoculture keep increasing (Ekadinata and Vincent, 2011; Gatto et al., 2015). We observed that farmers are willing to 
produce two crops simultaneously and proposed a hypothesis that farmers' risk aversion reasoned the crop-diversification.

Rubber yields vary due to rainwater and low humidity, resulting on unstable income during rainy season (Feintrenie et al., 2010; Miyamoto, 2006). Oil palm yields relatively more stable despite the seasons (Rist et al., 2010). However, the price of oil palm fruits is more volatile (cf. Figure III-1) and the yields are more perishable. Regarding the advantage and disadvantage of each crop, cultivating both helps to maximize the expected returns with minimum variances if the expected returns are not perfectly correlated. Our study found that farmers who cultivate two crops are more risk-averse than farmers who only cultivate rubber. These findings confirm the previous studies that found relationship between farmers' risk-averse and cropdiversification (e.g., Bezabih and Sarr., 2012; Chavas and Di Falco., 2012). In a country where agricultural insurance is not well-established (i.e., developing countries), crop-diversification is an effective alternative to mitigate income uncertainties (Dercon, 1996).

\subsection{Results: Hypothesis 2}

Panel $B$ of Table III-4 presents the estimated discount rate $\delta$. Model 1 show that $\delta$ of rubber farmers is 2.97, indicated annual discount rates of $297 \%$, and the discount rates of double-crop farmers are $206 \%$ annually. Model 2 shows the rubber farmers' discount rates are $274 \%$, and the double-crop farmers' discount rates are $256 \%$. These results indicate that double-crop farmers' discount rates are lower than rubber farmers. We carried out a t-test, to examine whether the discount rates of both groups are statistically significantly different. The t-test shows that the discount rates of both groups are not statistically significantly different (p-value $=0.16$ for model $1 ; \mathrm{p}$-value $=0.78$ for model 2 ). Hence, these results contradicted our expectation in hypothesis 2, which stated that "farmers with higher discount rate cultivate oil palms besides rubber." Therefore, we remark that farmers' discount rates are not different among the two groups, even though their risk attitude have an important role regarding cropdiversification.

We found that the discount rates are not statistically significantly different, but we encountered extremely high discount rates, i.e., above $200 \%$ annually. Compared to previous studies, the discount rates of farmers in our sample are extremely high (e.g., Hermann and Mußhoff, 2016; Skidmore et al., 2014). Regarding this, we applied two methodical approaches to avoid the overestimated discount rates: (1) using not too high the interest rate in the CWtask; (2) estimate the discount rates and risk attitudes simultaneously (Andersen et al., 2008). In our design, the upper border of interest rates is $100 \%$. Besides, we also estimate the discount 
rates and risk attitudes simultaneously. Nevertheless, high discount rates are common in developing countries (Holden et al., 1998), and the previous study also estimated a high discount rate, i.e., 250\% (Coble and Lusk., 2010).

\subsection{Robustness check}

We involve farmers' socioeconomic and demographic variables in the estimation to check the robustness and to examine the influence of those variables on the risk attitudes and discount rates. The results are presented in Table III-5. The dummy variable "double-crop farmer" is statistically significant at a $1 \%$ level regarding the risk attitudes but not significant regarding the discount rate. This result provides two remarks: (1) the risk attitudes of both groups are statistically significantly different, i.e., the double-crop farmers are more risk-averse; (2) the discount rates of both groups are not statistically significant ( $p$-value $=0.92)$. Therefore, the findings from model 1 and model 2 are maintained (cf. Table III-4). Furthermore, the variable “age" significantly influences farmers' risk attitudes at a 5\% significance level. This implies that older farmers are more risk-averse than younger farmers. Besides, the "loan" is statistically significant with a negative sign, showing that having a loan leads to lower risk aversion. However, none of the variables statistically significantly influence farmers' discount rates.

Table III-5. Model estimates of risk attitudes and time preferences with farmers' socioeconomic and demographic

\begin{tabular}{|l|c|c|}
\hline \multicolumn{1}{|c|}{ Variables (units) } & $\begin{array}{c}\text { Coefficients (st. error) for } \\
\text { the estimation of } \theta^{a}\end{array}$ & $\begin{array}{c}\text { Coefficients (st. error) for } \\
\text { the estimation of } \delta^{a}\end{array}$ \\
\hline Double-crop farmer (1 = double-crop) & $0.18(0.07) * * *$ & $1.01(0.59)$ \\
\hline Age (years) & $0.01(0.01) * *$ & $-0.02(0.03)$ \\
\hline Car (1/0) & $0.00(0.10)$ & $0.44(1.25)$ \\
\hline Gender (1/0) & $-0.13(-0.15)$ & $1.26(0.95)$ \\
\hline Land title (1/0) & $-0.09(-0.06)$ & $-0.08(0.66)$ \\
\hline Loan (1/0) & $-0.13(-0.06) *$ & $0.83(0.72)$ \\
\hline Motorbike & $0.02(0.03)$ & $0.41(0.36)$ \\
\hline Plantation age (years) & $0.00(0.00)$ & $0.03(0.04)$ \\
\hline Plantation area (ha) & $0.00(0.01)$ & $-0.02(0.08)$ \\
\hline Productive plantation (ha) & $-0.01(0.02)$ & $0.01(0.09)$ \\
\hline Saving (1/0) & $0.06(0.06)$ & $-0.95(0.62)$ \\
\hline Truck (1/0) & $-0.04(0.14)$ & $-1.38(2.22)$ \\
\hline
\end{tabular}

Notes: $\mathrm{N}$ for rubber farmers $=8,740$ (number of clusters $=437$ ), $\mathrm{N}$ for double-crop farmers $=3,980$ (number of clusters $=199)$; ${ }^{a}$ Significance levels: $* * *$ at $1 \%, * *$ at $5 \%$, * at $10 \%$, the significance level indicates the difference between the values of $\theta$ and zero

\section{Conclusions}

Farmers constituted a large share of the rural population in many developing countries. Hence, enhancing agriculture is utilised to accelerate the development of rural areas (Ashley and 
Maxwell, 2001). One policy measure to reduce income variance is crop-diversification. Regarding a decision to diversify crops, farmers' risk attitudes and time preferences are relevant information for a meaningful policy recommendation. However, the existing investigation is limited to seasonal/annual crops. This study investigates farmers' risk attitudes and time preferences regarding diversification of perennial crops. We conducted a study in Jambi Province, Indonesia, and involved two groups of farmers: rubber farmers and double-crop farmers, i.e., cultivate rubber and oil palms. We expected that the latter group is more riskaverse and have higher discount rates. This study generates two findings: (1) double-crop farmers are more risk-averse than rubber farmers; (2) the time preferences of both groups are not different.

This study provided empirical proof that experimentally measured risk attitudes explain farmers' decisions to diversify perennial crops. It enriches the literature that investigates cropdiversification of seasonal/annual crops. These findings can be a preliminary insight for policymakers when they plan to either encourage or discourage crop-diversification. Encourage crop-diversification means supporting oil palm adoption. In this regard, the government can consider increasing the number of mills to accommodate the perishable oil palm fruits. In contrast, if the government wants to focus on rubber production then financial incentive such as floor prices for rubber or agricultural insurances during rainy season could be implemented. Furthermore, even though we do not discover the difference in discount rates, we find that farmers' discount rates are extremely high. The policymakers and the farmers themselves must put consideration about these high discount rates. High discount rates hinder farmers' adoption on new technology, thereby resulting on slow growth and poverty (Stevenson et al., 2014).

Finally, we propose some outlooks for future research to extend our study. First, we used coloured images to explain the HL-task. Future research can modify the experiment by using randomisation of colours. This can be a useful strategy to prevent the possibility of colour bias. Second, future research can investigate farmers' motivation to diversify crops using in-depth interviews. Third, future research can extend the sample coverage by involving rubber farmers who switched entirely to oil palms. In this way, researcher can compare the risk attitudes and time preferences of farmers who diversify crops and farmers who switching crops. 


\section{References}

Aimin H. 2010. Uncertainty, risk aversion and risk management in agriculture. Agriculture and Agricultural Science Procedia 1: 152-156. https://doi.org/10.1016/j.aaspro.2010.09.018

Andersen S, Harrison GW, Lau MI, Rutström EE. 2008. Eliciting risk and time preference. Econometrica 76(3): 583-618. https://doi.org/10.1111/j.1468-0262.2008.00848.X

Ashley C, Maxwell S. 2001. Rethinking rural development. Development policy review 19(4): 395-425. https://doi.org/10.1111/1467-7679.00141

Bezabih M, Sarr M. 2012. Risk preferences and environmental uncertainty: Implications for crop diversification decisions in Ethiopia. Environmental and Resource Economics 53(4): 483-505. https://doi.org/10.1007/s10640-012-9573-3

Bocqueho G, Jacquet F. 2010. The adoption of switchgrass and miscanthus by farmers: Impact of liquidity constraints and risk preferences. Energy Policy 38(5): 2598-2607. https://doi.org/10.1016/j.enpol.2010.01.005

Brandi C, Cabani T, Hosang C, Schirmbeck S, Westermann L, Wiese, H. 2015. Sustainability standards for palm oil: challenges for smallholder certification under the RSPO. The Journal of Environment \& Development 24(3): 292-314. https://doi.org/10.1177/1070496515593775

Coller M, Williams MB. 1999. Eliciting individual discount rates. Experimental Economics 2(2): 107-127. https://doi.org/10.1023/A:1009986005690

Chavas JP, Di Falco S. 2012. On the role of risk versus economies of scope in farm diversification with an application to Ethiopian farms. Journal of Agricultural Economics 63(1): 25-55. https://doi.org/10.1111/j.1477-9552.2011.00319.x

Clough Y, Krishna VV, Corre MD, Darras K, Denmead LH, Meijide A, Moser S, Mußhoff O, Steinebach S, Veldkamp E, Allen K, Barnes AD, Breidenbach N, Brose U, Buchori D, Daniel R, Finkeldey R, Harahap I, Hertel D, Holtkamp AM, Hörandl E, Irawan B, Jaya INS, Jochum M, Klarner B, Knohl A, Kotowska MM, Krashevska V, Kreft H, Kurniawan S, Leuschner C, Marau M, Melati DN, Opfermann N, Pérez-Cruzado C, Prabowo WE, Rembold K, Rizali A, Rubiana R, Schneider D, Tjitrosoedirdjo SS, Tjoa A, Tscharntke T, Scheu. S. 2016. Land-use choices follow profitability at the expense of ecological functions in Indonesian smallholder landscapes. Nature Communications 7: 13137. https://doi.org/10.1038/ncomms13137

Coble KH, Lusk JL. 2010. At the nexus of risk and time preferences: An experimental investigation. Journal of Risk and Uncertainty 41(1): 67-79. https://doi.org/10.1007/s11166-010-9096-7

Corley RHV, Tinker PB. 2016. The oil palm: Fifth edition. Wiley Blackwell, United Kingdom. https://doi.org/10.1002/9781118953297

Cox CM, Garrett KA, Bockus WW. 2005. Meeting the challenge of disease management in perennial grain cropping systems. Renewable Agriculture and Food Systems 20(1): 1524. https://doi.org/10.1079/RAF200495

Dercon, S. 1996. Risk, crop choice, and savings: Evidence from Tanzania. Economic Development and Cultural Change 44(3): 485-513. https://doi.org/10.1086/452229

Drescher J, Rembold K, Allen K, Beckschäfer P, Buchori D, Clough Y, Faust H, Fauzi AM, Gunawan D, Hertel D, Irawan B, Jaya INS, Klarner B, Kleinn C, Knohl A, Kotowska MM, Krashevska V, Krishna V, Leuschner C, Lorenz W, Meijide A, Melati D, Nomura M, Perez-Cruzado C, Qaim M, Siregar IZ, Steinebach S, Tjoa A, Tscharntke T, Wick B, Wiegand K, Kreft H, Scheu S. 2016. Ecological and socio-economic functions across tropical and land use system after rainforest conversion. Philosophical Transactions of the Royal Society B.371: 1-8. https://doi.org/10.1098/rstb.2015.0275 
Ekadinata A, Vincent G. 2011. Rubber agroforests in a changing landscape: analysis of land use/cover trajectories in Bungo district, Indonesia. Forests, Trees and Livelihoods 20(1):3-14. https://doi.org/10.1080/14728028.2011.9756694

Ellis L, Ficek C. 2001. Color preferences according to gender and sexual orientation. Personality and Individual Differences 31: 1375-1379. https://doi.org/10.1016/S0191$\underline{8869(00) 00231-2}$

Falk A, Becker A, Dohmen T, Enke B, Huffman D, Sunde U. 2018. Global evidence on economic preferences. The Quarterly Journal of Economics 133(4): 1645-1692. https://doi.org/10.1093/qje/qjy013

Feder G. 1980. Farm size, risk aversion and the adoption of new technology under uncertainty. $\begin{array}{llll}\text { Oxford Economic } & \text { 32(2): }\end{array}$ https://doi.org/10.1093/oxfordjournals.oep.a041479

Feintrenie L, Levang P. 2009. Sumatra's rubber agroforests: Advent, rise and fall of a sustainable cropping system. Small-scale Forestry 8(3): 323-335. https://doi.org/10.1007/s11842-009-9086-2

Feintrenie L, Chong WK, Levang P. 2010. Why do farmers prefer oil palm? Lessons learnt from Bungo district, Indonesia. Small-scale forestry 9(3): 379-396. https://doi.org/10.1007/s11842-010-9122-2

Gatto M, Wollni M, Qaim M. 2015. Oil palm boom and land-use dynamics in Indonesia: The role of policies and socioeconomic factors. Land Use Policy 45: 292-303. https://doi.org/10.1016/j.landusepol.2015.03.001

Gilbert CL, Morgan CW. 2010. Food price volatility. Philosophical Transactions of the Royal Society of London B: Biological Sciences 365(1554): 3023-3034. https://doi.org/10.1098/rstb.2010.0139

Grass I, Kubitza C, Krishna VV, Corre MD, Mußhoff O, Pütz P, Drescher J, Rembold K, Ariyanti ES, Barnes AD, Brinkmann N, Brose U, Brümmer B, Buchori D, Daniel R, Darras KFA, Faust H, Fehrmann L, Hein J, Hennings N, Hidayat P, Hölscher D, Jochum M, Knohl A, Kotowska MM, Krashevska V, Kreft H, Leuschner C, Lobite NJS, Panjaitan R, Polle A, Potapov AM, Purnama E, Qaim M, Röll A, Scheu S, Schneider D, Tjoa A, Tscharntke T, Veldkamp E, Wollni M. 2020. Trade-offs between multifunctionality and profit in tropical smallholder landscapes. Nature Communications. 11(1):1-3. https://doi.org/10.1038/s41467-020-15013-5

Heady EO. 1952. Diversification in resource allocation and minimization of income variability. Journal of Farm Economics 34(4): 482-496. https://doi.org/10.2307/1233230

Hellerstein D, Higgins N, Horowitz J. 2013. The predictive power of risk preference measures for farming decisions. European Review of Agricultural Economics 40(5): 807-833. https://doi.org/10.1093/erae/jbs043

Hermann, D., Mußhoff, O. 2016. Measuring time preferences: Comparing methods and evaluating the magnitude effect. Journal of Behavioral and Experimental Economics 65:16-26. https://doi.org/10.1016/j.socec.2016.09.003

Hertwig R, Ortmann A. 2001. Experimental practices in economics: A methodological challenge for psychologists?' Behavioral and Brain Sciences 24: 383-451. https://doi.org/10.2139/ssrn.1129845

Hidayat NK, Glasbergen P, Offermans A. 2015. Sustainability certification and palm oil smallholders' livelihood: A comparison between scheme smallholders and independent smallholders in Indonesia. International Food and Agribusiness Management Review 18(3): 25-48.

Holden ST, Bekele S, Wik M. 1998. Poverty, market imperfections and time preferences: of relevance for environmental policy? Environment and Development Economics 3(1): 105-130. https://doi.org/10.1017/S1355770X98000060 
Holden ST, Quiggin J. 2017. Climate risk and state-contingent technology adoption: shocks, drought tolerance and preferences. European Review of Agricultural Economics 44(2): 285-308. https://doi.org/10.1093/erae/jbw016

Holt CA, Laury SK. 2002. Risk aversion and incentive effects. American Economic Review 92(5): 1644-1655. https://dx.doi.org/10.2139/ssrn.893797.

Hurlbert AC, Ling Y. 2007. Biological components of sex differences in color preferences. Current Biology 17. https://doi.org/10.1016/j.cub.2007.06.022

Ihli HJ, Chiputwa, B, Mußhoff, O. 2016. Do changing probabilities or payoffs in lottery-choice experiments affect risk preference outcomes? Evidence from rural Uganda. Journal of Agricultural and Resource Economics 41: 324-345.

Krishna VV, Kubitza C, Pascual U, Qaim M. 2017. Land markets, property rights, and deforestation: insights from Indonesia. World Development 99: 335-349. https://doi.org/10.1016/j.worlddev.2017.05.018

Kubitza C, Krishna VV, Alamsyah Z, Qaim M. 2018. The economics behind an ecological crisis: livelihood effects of oil palm expansion in Sumatra, Indonesia. Human Ecology 46(1):107-16. https://doi.org/10.1007/s10745-017-9965-7

Laury SK, McInnes MM, Swarthout, J. T. 2012 Avoiding the curves: Direct elicitation of time preferences. Journal of Risk and Uncertainty 44(3): 181-217. https://doi.org/10.2139/ssrn.1754082

Lawrance EC. 1991. Poverty and the rate of time preference: Evidence from panel data. Journal of Political Economy 99(1): 54-77. https://doi.org/10.1086/261740

Lien G, Hardaker JB. 2001. Whole-farm planning under uncertainty: Impacts of subsidy scheme and utility function on portfolio choice in Norwegian agriculture. European Review of Agricultural Economics 28(1): 17-36. https://doi.org/10.1093/erae/28.1.17

Lobell DB, Field CB, Cahill KN, Bonfils C. 2006. Impacts of future climate change on California perennial crop yields: Model projections with climate and crop uncertainties. Agricultural and Forest Meteorology 141(2-4): 208-218. https://doi.org/10.1016/j.agrformet.2006.10.006

Luce RD. 1959. Individual Choice Behavior (a theoretical analysis). John Wiley \& Sons, Inc, New York, United States of America.

Markowitz H. 1952. Portfolio selection. The journal of finance 7(1): 77-91. https://doi.org/10.1111/j.1540-6261.1952.tb01525.x

Marimin, Darmawan MA, Putra MPIF. 2014. Wiguna, B. Value chain analysis for green productivity improvement in the natural rubber supply chain: A case study. Journal of Cleaner Production 85: 201-211. https://doi.org/10.1016/j.jclepro.2014.01.098

Miyamoto M. 2006. Forest conversion to rubber around Sumatran villages in Indonesia: Comparing the impacts of road construction, transmigration projects and population. Forest Policy and Economics 9(1): 1-12. https://doi.org/10.1016/j.forpol.2005.01.003

Ngwira AR, Thierfelder C, Eash N, Lambert DM. 2013. Risk and maize-based cropping systems for smallholder Malawi farmers using conservation agriculture technologies. Experimental Agriculture 49(4): 483-503. https://doi.org/10.1017/S0014479713000306

Nielsen T, Keil A, Zeller M. 2013. Assessing farmers' risk preferences and their determinants in a marginal upland area of Vietnam: a comparison of multiple elicitation techniques. Agricultural Economics, 44(3):255-273. https://doi.org/10.1111/agec.12009

Ouattara PD, Kouassi E, Egbendéwé AYG, Akinkugbe O. 2019. Risk aversion and land allocation between annual and perennial crops in semisubsistence farming: a stochastic optimization approach. Agricultural Economics, 50: 329-339. https://doi.org/10.1111/agec.12487

Pellegrini L, Tasciotti L. 2014. Crop diversification, dietary diversity and agricultural income: empirical evidence from eight developing countries. Canadian Journal of Development 
Studies/Revue canadienne d'études du développement. 3;35(2):211-27. https://doi.org/10.1080/02255189.2014.898580

Rembold K, Mangopo H, Tjitrosoedirdjo SS, Kreft H. 2017. Plant diversity, forest dependency, and alien plant invasions in tropical agricultural landscapes. Biological Conservation 213: 234-242. https://doi.org/10.1016/j.biocon.2017.07.020

Rist L, Feintrenie L, Levang P. 2010. The livelihood impact of oil palm: Smallholders in Indonesia. Biodiversity and Conservation 19(4): 1009-1024. https://doi.org/10.1007/s10531-010-9815-z

Sauter PA, Mußhoff O. 2018. What is your discount rate? Experimental evidence of foresters' risk and time preferences. Annals of Forest Science 75(1): 10. https://doi.org/10.1007/s13595-017-0683-5

Skidmore S, Santos P, Leimona B. (2014) Targeting REDD+: An Empirical Analysis of Carbon Sequestration in Indonesia, World Development 64: 781-790. http://dx.doi.org/10.1016/j.worlddev.2014.07.013

Tanaka T, Camerer CF, Nguyen Q. 2010 Risk and time preferences: Linking experimental and household survey data from Vietnam. American Economic Review 100(1): 557-71. https://doi.org/10.1257/aer.100.1.557

Taylor R, 1990. Interpretation of the correlation coefficient: a basic review. Journal of $\begin{array}{llll}\text { diagnostic medical sonography } & \mathbf{6}(1) \text { : }\end{array}$ https://doi.org/10.1177\%2F875647939000600106

Turvey CG, Kong R. 2010. Weather risk and the viability of weather insurance in China's Gansu, Shaanxi, and Henan provinces. China Agricultural Economic Review 2(1): 5-24. https://doi.org/10.1108/17561371011017469

Wilcove DS, Koh LP. 2010. Addressing the threats to biodiversity from oil-palm agriculture. Biodiversity and Conservation 19(4): 999-1007. https://doi.org/10.1007/s10531-0099760-X

Woittiez LS, Van Wijk MT, Slingerland M, Van Noordwijk M, Giller KE. 2017. Yield gaps in oil palm: A quantitative review of contributing factors. European Journal of Agronomy 83: 57-77. https://doi.org/10.1016/j.eja.2016.11.002 


\section{Appendix}

Table III-A1. Holt and Laury task

\begin{tabular}{|c|c|c|}
\hline 1 & Option (A or B) \\
\hline 2 & & \\
\hline
\end{tabular}

Notes: due to page limitation, we only present the row 1 and 2 here

Table III-A2. Correlation coefficients for farmers' socioeconomic and demographic variables and selection for option $A$ or option $B$ in the HL-task

\begin{tabular}{|l|l|c|c|}
\hline \multirow{2}{*}{ Variables (unit) } & \multicolumn{1}{|c|}{ Variables' explanations } & \multicolumn{2}{c|}{ Correlation coefficient $(\rho)$} \\
\cline { 3 - 4 } & & Rubber farmers & Double-crop farmers \\
\hline Age (years) & Age of farmer & 0.12 & -0.04 \\
\hline Car (1/0) & $=1$ if own cars & 0.04 & -0.17 \\
\hline Gender (1/0) & $=1$ if male & -0.05 & -0.05 \\
\hline Land title (1/0) & $=1$ if official title & -0.06 & -0.03 \\
\hline Loan (1/0) & $=1$ if own loan & -0.11 & -0.01 \\
\hline Motorbike & Number of motorbikes & 0.00 & 0.04 \\
\hline Plantation age (years) & Age of plantations & 0.06 & -0.02 \\
\hline Plantation area (ha) & Size of plantation areas & 0.07 & -0.16 \\
\hline Productive area (ha) & Size of productive plantation areas & 0.04 & -0.14 \\
\hline Saving (1/0) & $=1$ if own saving & 0.00 & 0.02 \\
\hline Truck (1/0) & $=1$ if own trucks & -0.02 & -0.05 \\
\hline
\end{tabular}

Notes: $\mathrm{N}=636$ (437 rubber farmers, 199 double-crop farmers) 


\title{
IV. Risk attitudes and time preferences of smallholder farmers in two comparable Asian countries: a study in India and Indonesia
}

Arieska Wening Sarwosri, Oliver Mußhoff

This paper has been submitted in:

Journal of South Asian Development

Original submitted July 2021

An earlier version of this paper has been published in:

EFForTS Discussion Paper Series, April 2020, No. 32

\begin{abstract}
This study elicits risk attitude and time preferences of farmers in rural areas in the two countries, India and Indonesia, involving 1,528 farmers. It provides a direct country comparison of two countries that are currently experiencing a similar process of structural change. Thus, prior information of farmers' risk attitude and time preference may provide a preliminary insight for policymakers to make informed policies for future development projects and the adoption of technology in agriculture. Otherwise, critical elements to predict farmers' investment or disinvestment are missing. To do so, we conducted an incentivised Holt and Laury-task and Coller and Williams-task experiment using the joint-estimation-method. We found that farmers in both countries have an extremely high discount rate, but on average they are slightly risk-averse.
\end{abstract}

\section{Keywords:}

cross-countries datasets, farmers, risk attitudes, structural changes, time preferences

JEL Classifications: D81, D91, 018 


\section{Introduction}

The investigation of farmer's risk attitudes and time preferences in developing countries are important preliminary insights for future policies regarding development projects. Farmers in developing countries often have limited access to credit and insurance while facing various shocks and high inflation rate (Fafchamps, 2003). They also suffer from the price fluctuation, uncertain access to inputs, and unclear land ownership's (Barrett et al., 2012; Lee, 2005). Studies have investigated the relationship between farmers' risk attitude and farmers' decision for microcredit's application, innovation' adoption or agricultural insurance (e.g., Jin et al., 2016; McIntosh et al., 2013; Ngwira et al., 2013). Risk aversion holds farmers in a povertytrap within the cycle: reluctant to adopt - being left out from innovations' benefits - stay poor (Brick and Visser, 2015; Knight et al., 2003). Farmers' time preferences are a vital consideration when policymakers plan to implement a long-term investment project. Without financial incentives or other supporting programs, farmers who favour a high discount rate are unlikely to participate (e.g., Bauer and Chytilová., 2010; Bauer et al., 2013).

This study aims to provide insight about the risk attitude and time preference of rural farmers in India and Indonesia, helping policymakers to make informed decisions about future projects. It also presents a comparison between the preferences of Indian and Indonesian rural farmers. Several considerations have been put in conducting the studies in these two countries. Firstly, they are currently experiencing structural changes, where farmers are slowly leaving the subsistence farming and producing cash crops (e.g., Finnis, 2006; Grass et al., 2020). When the structural changes are happening, the farmers are facing the options of investment and disinvestment for a particular cash crop or a new farming system. In this circumstance, the knowledge about farmers' risk attitude and discount rate would be important elements when the policymakers make a forecast for investment and disinvestment. Otherwise, they will not come to a meaningful future policy.

Secondly, interm of population, India and Indonesia belong to the top four countries in the world. Both countries have high population growth, 37\% for India and 32\% for Indonesia (World Bank, 2018). Together with the huge population, the poverty among small-scale farmers is also major in these two countries while compared to others high-populated countries, e.g., China and United States of America. Thirdly, India and Indonesia also deal with the rapid urbanisation as indicated by higher urban population growth than total population (Bharath et al., 2018; Ramachandra et al., 2015; World Bank, 2018; Zhu and Simarmata, 2015). The 
urbanisation promotes problems such as decreasing young generations in farming (Patil et al., 2019).

The fieldwork involved 772 Indian and 756 Indonesian farmers. During the fieldwork, we carried out two experiments: (1) the Holt and Laury task (HL-task) to observe risk attitudes; and (2) the Coller and Williams task (CW-task) to measure time preferences by estimating the discount rate (Coller and Williams, 1999; Holt and Laury, 2002). Incentives (monetary payments) were given to encourage a sensible decision during the experiment (Hertwig and Ortman, 2001). The risk attitudes and time preferences are estimated simultaneously using the joint-estimation-method (Andersen et al., 2008). In this method, the discount rate is estimated by involving the risk attitudes coefficients instead of assuming risk neutrality (see Andersen $e t$ al., 2008; Anderhub et al., 2001; Laury et al., 2012). For robustness check, we estimated farmers' risk attitude and discount rate by involving socioeconomic characteristics as control variables.

To date, studies of farmers' risk attitude and discount rate were conducted usually in a single country (e.g., Bauer et al., 2012; Nguyen, 2011; Tanaka et al., 2010). Likewise, if research was based in two or more countries, they did not focus on farmers (e.g., Falk et al., 2018). Our study was a direct country comparison in one paper without being a review or meta paper. This comes with the advantage that the experimental framework conditions in both countries were perfectly harmonised. For instance, the data collection was conducted at a similar time frame which anticipated changes in the economic conditions, using the same elicitation method (HL-task and $\mathrm{CW}$-task), and focused only on farmers. Furthermore, this study extended on previous research that focused only on risk attitudes or time preferences. For example, Harrison et al. (2009) study, compared farmers' risk attitudes in three different income levels countries but did not discuss the time preferences. The same could be said for the study by Wang et al. (2016) which compared the time preferences of students in a laboratory experiment from many countries but neglected the discussion of risk attitude. To focus on the elicitation of risk attitudes and time preferences at the same time is advantageous because it allows risk attitudes to be considered when calculating time preference, rather than assuming risk neutrality. Therefore, this study is novel in terms of involving two countries, risk and time preferences as well as focusing on farmers.

This paper is structured as follows: Section 2 presents the data and descriptive statistics. Section 3 presents the methodology. Section 4 explains and discusses the results. Section 5 provides a conclusion and the policy implications of the findings. 


\section{Data and descriptive statistics}

The fieldwork was conducted in two countries, Indonesia and India, at an almost simultaneous time frame to anticipate changes in the economic conditions (end of 2016 until the beginning of 2017). Together with the measurement of farmers' risk attitudes and discount rate, we also surveyed farmers' socioeconomic and demographic information. In the estimation of farmers' risk attitude and discount rate, the socioeconomic and demographic information was used as control variables (see section 4.2). The explanation of the study's location and the detail information about how the sample was selected are as follows:

(1) India's fieldwork was conducted in rural areas around Bangalore city and took place from December 2016 to May 2017. In line with the ongoing research project (see Hoffmann et al., 2017; Wegmann and Mußhoff, 2019), two research transects (north and south) representing three urbanisation stages - urban, peri-urban, and rural, were selected. A stratified random sampling procedure was applied to select the sample households. First, each transect was divided into six strata, using the Survey Stratification Index (SSI). SSI is constructed using two variables - the distance to the city centre, and the proportion of buildup area measures the rural-urban gradient (Hoffmann et al., 2017). From the resulting 12 strata, 61 villages/urban wards were selected randomly proportional to each stratum's size. Then, in each of the sample village/urban ward, around 20 households were randomly selected proportional to the village's size using the household lists from the kindergarten that were regularly updated. Focusing on this study's objectives, we only used part of the dataset, which involves participants living in the rural area (village). Therefore, this study involved 42 rural areas and 772 farmers.

(2) The fieldwork in Indonesia was conducted in the rural area surrounding Jambi city. In line with the ongoing research project (see Clough et al., 2016), the study took place in five regencies $^{23}$, including Batanghari, Bungo, Muaro Jambi, Sarolangun, and Tebo regency ${ }^{24}$. Eight villages were selected randomly from the village lists of each regency, and five villages were purposively selected. Thus, there are 45 villages included in this study. We randomly selected the farmers from the farmers' list from each village provided by the village heads or the leader of the farmers' group. We involved 8 to 24 farmers per village

\footnotetext{
${ }^{23}$ Regency is a term used for an administrative division of area in Indonesia. Each province in Indonesia is divided into several regencies.

${ }^{24}$ These five regencies surrounded two forest areas, namely Bukit Duabelas and Harapan Forest Restoration, where the forest's transformation into agricultural land massively occurred (Clough et al., 2016).
} 
depending on the population size of farmers per village, resulting in a total of 756 farmers. The work lasted from October 2016 until January 2017.

To provide an overview about farmers' socio-demographic backgrounds, descriptive statistics are presented in Table IV-1. We surveyed farmers' age, education, household size, and some binary variables such as gender, full-time farmers status, and a loan from formal or informal institutions. The Indian farmers were slightly younger and have shorter formal education than Indonesian farmers. The Indian farmers lived in larger households compared to Indonesians. During the data collection, we defined the "full-time farmers" are the farmers who obtain more than $50 \%$ of income from farming activities. Out of the sample, $87 \%$ from Indonesia and $77 \%$ from India are full-time farmers. In both countries, most of the surveyed farmers are male, but more female farmers are captured in India, i.e., $27 \%$ vs. 3\%. A loan from an informal institution is more common among Indian farmers (i.e., 26\% vs. 2\%) than in Indonesia, where $20 \%$ of them have loans. Meanwhile, only $2 \%$ of Indonesian farmers have a loan from informal institutions. In contrast, more farmers in Indonesia have a loan from formal institutions (48\%) than in India (32\%).

Table IV-1. Descriptive statistics of Indian and Indonesian farmers

\begin{tabular}{|l|l|c|c|}
\hline \multirow{2}{*}{ Variables (units) $^{a}$} & \multicolumn{1}{|c|}{ Variables' explanations $^{\prime}$} & \multicolumn{2}{c|}{ Mean (Std. dev.) / share in \% } \\
\cline { 3 - 4 } & & India & Indonesia \\
\hline Age (year-old) & Age of farmer & $45.15(13.96)$ & $46.53(10.24)$ \\
\hline Education (years) & Formal education & $6.25(5.05)$ & $8.36(3.57)$ \\
\hline Full-time farmer (1/0) & $=1$ if $\geq 50 \%$ income from farming & $77 \%$ & $87 \%$ \\
\hline Gender (1/0) & $=1$ if male & $73 \%$ & $97 \%$ \\
\hline Household size & The numbers of household members & $4.66(2.19)$ & $4.27(1.43)$ \\
\hline Loan formal (1/0) & $=1$ if has loan from formal institutions & $32 \%$ & $48 \%$ \\
\hline Loan informal (1/0) & $=1$ if has loan from informal institutions & $26 \%$ & $2 \%$ \\
\hline Sample size & 772 & 756 \\
\hline
\end{tabular}

(Notes: ${ }^{a}$ Significance levels: $* * *$ at $1 \%, * *$ at $5 \%$, $*$ at $10 \%$ )

\section{Methodology}

The fieldwork was supported by several fieldwork-assistants who spoke the local language to conduct "one-by-one experiments," where one field assistant helped one farmer perform the tasks. To help the farmers better understand the tasks, we used coloured pictures. In this way, we helped the farmers who were illiterate or have limitation to read.

\subsection{The HL-task and CW-task}

Following Holt and Laury (2002), there were ten rows of paired lotteries in the HL-task. Each row consisted of two options: $A$ or $B$. Every option included a pair of payoffs: high payoff and 
low payoff. The difference between the payoffs in option $A$ was less than in option $B$. Thus, option $A$ was the "safe-option," and option $B$ was the "risky-option." The probability of gaining a high payoff increased as farmers moved down to the tenth row (cf. Table 2). The risk attitudes were determined when the farmers switched from selecting option $A$ to option $B$ for the first time. For practical reasons, we visualised the tasks using coloured pictures to depict the payoffs in the HL-task. As for the CW-task, the task was much simpler, and we used a table depicting the ten rows of the two options.

Table IV-2. Multiple price list of the HL-task of Indian and Indonesian farmers

\begin{tabular}{|c|c|c|c|c|c|c|}
\hline \multirow{2}{*}{ Row $^{a}$} & \multicolumn{3}{|c|}{ India } & \multicolumn{3}{|c|}{ Indonesia } \\
\hline & Option $A$ (INR) & Choice & Option $B$ (INR) & Option $A$ (IDR) & Choice & Option $B$ (IDR) \\
\hline 1 & $\begin{array}{l}10 \% \text { of } 100 \\
90 \% \text { of } 80\end{array}$ & $\cdots$ & $\begin{array}{l}10 \% \text { of } 192, \\
90 \% \text { of } 5\end{array}$ & $\begin{array}{l}10 \% \text { of } 4,000, \\
90 \% \text { of } 3,200\end{array}$ & $\cdots$ & $\begin{array}{l}10 \% \text { of } 7,600, \\
90 \% \text { of } 200\end{array}$ \\
\hline 2 & $\begin{array}{l}20 \% \text { of } 100, \\
80 \% \text { of } 80\end{array}$ & $\cdots$ & $\begin{array}{l}20 \% \text { of } 192, \\
80 \% \text { of } 5\end{array}$ & $\begin{array}{l}20 \% \text { of } 4,000 \\
80 \% \text { of } 3,200\end{array}$ & $\cdots$ & $\begin{array}{l}20 \% \text { of } 7,600, \\
80 \% \text { of } 200\end{array}$ \\
\hline 3 & $\begin{array}{l}30 \% \text { of } 100, \\
70 \% \text { of } 80\end{array}$ & $\ldots$ & $\begin{array}{l}30 \% \text { of } 192, \\
70 \% \text { of } 5\end{array}$ & $\begin{array}{l}30 \% \text { of } 4,000 \\
70 \% \text { of } 3,200\end{array}$ & $\cdots$ & $\begin{array}{l}30 \% \text { of } 7,600, \\
70 \% \text { of } 200\end{array}$ \\
\hline 4 & $\begin{array}{l}40 \% \text { of } 100, \\
60 \% \text { of } 80\end{array}$ & $\cdots$ & $\begin{array}{l}40 \% \text { of } 192, \\
60 \% \text { of } 5\end{array}$ & $\begin{array}{l}40 \% \text { of } 4,000, \\
60 \% \text { of } 3,200\end{array}$ & $\cdots$ & $\begin{array}{l}40 \% \text { of } 7,600, \\
60 \% \text { of } 200\end{array}$ \\
\hline 5 & $\begin{array}{l}50 \% \text { of } 100 \\
50 \% \text { of } 80\end{array}$ & $\cdots$ & $\begin{array}{l}50 \% \text { of } 192, \\
50 \% \text { of } 5\end{array}$ & $\begin{array}{l}50 \% \text { of } 4,000, \\
50 \% \text { of } 3,200\end{array}$ & $\cdots$ & $\begin{array}{l}50 \% \text { of } 7,600, \\
50 \% \text { of } 200\end{array}$ \\
\hline 6 & $\begin{array}{l}60 \% \text { of } 100, \\
40 \% \text { of } 80\end{array}$ & $\cdots$ & $\begin{array}{l}60 \% \text { of } 192, \\
40 \% \text { of } 5\end{array}$ & $\begin{array}{l}60 \% \text { of } 4,000, \\
40 \% \text { of } 3,200\end{array}$ & $\cdots$ & $\begin{array}{l}60 \% \text { of } 7,600, \\
40 \% \text { of } 200\end{array}$ \\
\hline 7 & $\begin{array}{l}70 \% \text { of } 100, \\
30 \% \text { of } 80\end{array}$ & $\cdots$ & $\begin{array}{l}70 \% \text { of } 192, \\
30 \% \text { of } 5\end{array}$ & $\begin{array}{l}70 \% \text { of } 4,000, \\
30 \% \text { of } 3,200\end{array}$ & $\cdots$ & $\begin{array}{l}70 \% \text { of } 7,600, \\
30 \% \text { of } 200\end{array}$ \\
\hline 8 & $\begin{array}{l}80 \% \text { of } 100, \\
20 \% \text { of } 80\end{array}$ & $\cdots$ & $\begin{array}{l}80 \% \text { of } 192, \\
20 \% \text { of } 5\end{array}$ & $\begin{array}{l}80 \% \text { of } 4,000, \\
20 \% \text { of } 3,200\end{array}$ & $\cdots$ & $\begin{array}{l}80 \% \text { of } 7,600, \\
20 \% \text { of } 200\end{array}$ \\
\hline 9 & $\begin{array}{l}90 \% \text { of } 100, \\
10 \% \text { of } 80\end{array}$ & $\ldots$ & $\begin{array}{l}90 \% \text { of } 192, \\
10 \% \text { of } 5\end{array}$ & $\begin{array}{l}90 \% \text { of } 4,000 \\
10 \% \text { of } 3,200\end{array}$ & $\cdots$ & $\begin{array}{l}90 \% \text { of } 7,600, \\
10 \% \text { of } 200\end{array}$ \\
\hline 10 & $100 \%$ of 100 & $\ldots$ & $100 \%$ of 192 & $100 \%$ of 4,000 & $\ldots$ & $100 \%$ of 7,600 \\
\hline
\end{tabular}

(Notes: ${ }^{a}$ INR is Indian Rupee, IDR is Indonesian Rupiah, $1 \$$ is approximately equal to 68.03 INR or 13,300 IDR).

In the CW-task, the farmers are confronted with two options of payoffs: option $I$ and $I I$. Option $I I$ was the sum of the value of the option $I$ plus an interest rate. The payoffs of option $I I$ were offered later than the option $I$ (Coller and Williams, 1999). In our design, the option $I$ was a payoff in one week. The value of option I was 120 Indian Rupee (INR) or 50,000 Indonesian Rupiah (IDR); for Indian and Indonesian farmers, respectively. Option II was a payoff in three months, where the interest rate ranged from $10 \%$ to $100 \%$ in the annual term. Option I was delayed for one week for two reasons. Firstly, the delay for both payoffs mitigated the immediate temptation and gave the same ascertained risk for both options because they were given in the future (Andersen et al., 2008). Secondly, we arranged a local shop for organising 
the transfer for mobile recharge and exchanging the shopping vouchers. The paired options of the CW-task are presented in Table 3.

Table IV-3. Payoff matrix of the CW-task of Indian and Indonesian farmers

\begin{tabular}{|c|c|c|c|c|c|c|}
\hline \multirow{2}{*}{$\begin{array}{c}\text { Row } \\
a\end{array}$} & \multicolumn{3}{|c|}{ India } & \multicolumn{3}{c|}{ Indonesia } \\
\cline { 2 - 7 } & Option I (INR) & Choice & Option II (INR) & Option I (IDR) & Choice & \multirow{2}{*}{ Option II (IDR) } \\
\hline 1 & 120 & $\ldots$ & 123 & 50,000 & $\ldots$ & 51,300 \\
\hline 2 & 120 & $\ldots$ & 126 & 50,000 & $\ldots$ & 52,500 \\
\hline 3 & 120 & $\ldots$ & 129 & 50,000 & $\ldots$ & 53,800 \\
\hline 4 & 120 & $\ldots$ & 132 & 50,000 & $\ldots$ & 55,200 \\
\hline 5 & 120 & $\ldots$ & 135 & 50,000 & $\ldots$ & 56,500 \\
\hline 6 & 120 & $\ldots$ & 138 & 50,000 & $\ldots$ & 57,900 \\
\hline 7 & 120 & $\ldots$ & 141 & 50,000 & $\ldots$ & 59,300 \\
\hline 8 & 120 & $\ldots$ & 144 & 50,000 & $\ldots$ & 60,700 \\
\hline 9 & 120 & $\ldots$ & 147 & 50,000 & $\ldots$ & 62,000 \\
\hline 10 & 120 & $\ldots$ & 150 & 50,000 & $\ldots$ & 63,600 \\
\hline
\end{tabular}

(Notes: ${ }^{a}$ INR is Indian Rupee, IDR is Indonesian Rupiah, $1 \$$ is approximately equal to 68.03 INR or 13,300 IDR. Option $I$ was a payment in one week and option $I I$ was a payment in three months)

\subsection{Monetary incentives}

Monetary incentives were given to both $\mathrm{HL}$ and $\mathrm{CW}$ tasks. In each task, the farmers made ten decisions. For the monetary incentives, one of these decisions was chosen randomly and farmers received the incentive according to their choice of option A or B. The monetary incentives consisted of mobile recharge for Indian farmers and a shopping voucher for daily groceries for Indonesia's farmers.

Slightly different tools were utilised to determine the HL-task's monetary incentives. In India, we used a ten-sided dice depicting the ten rows of paired lottery and to indicate the payoffs. First, the farmers rolled the die to randomly select one of the ten rows. Depending on their previous choice during the task, they were assigned to option A or option B of that row. Then they rolled the die a second time to determine high or low payoff - for example, in a row with $30 \%$ chance of high payoff and $70 \%$ of low payoff, numbers 1 to 3 represent high payoff and numbers 4 to 10 represent low payoff. In Indonesia, we used ten-numbered coins to depict the ten rows of paired lotteries. The farmers blindly picked a coin to determine the row and were assigned to option A or option B of that row. In the second step, bags with coloured balls were used to determine high or low payoff. For example, in a row with $30 \%$ of high payoff and $70 \%$ of low payoff, there were 3 red balls and 7 yellow balls in the bag, of which the farmer drew one. In the CW-task, like the HL-task, only one randomly selected row is binding to determine the monetary incentives. To randomly select the row, the Indian farmers hrewt a ten- 
sided die, and the Indonesian farmers blindly took one out of ten-numbered coins. The number indicates from which row is the monetary incentive. One US\$ is approximately equal to 68.03 INR or 13,300 IDR. The amount of baseline payoff (the option $I$ ) is the daily wage of nonskilled labour in a rural area, indicating that these values are not trivial.

\subsection{Maximum likelihood estimation}

The farmers' risk attitudes and time preferences are estimated simultaneously using the jointestimation method following Andersen et al. (2008). To estimate the risk attitudes, we assume a power risk utility function with constant relative risk aversion (CRRA; Andersen et al., 2008):

$U(X)=\frac{X^{1-\theta}}{1-\theta}$

The utility was denoted as $U$, the payoffs in the HL-task were denoted as $X$, and $\theta$ was the CRRA coefficient ${ }^{25}$. Each pair of lotteries in the HL-task consisted of a high payoff $(h)$ with the respective probabilities $\left(p_{i}\right)$ and the low payoff $(l)$ with the respective probabilities $1-p_{i}$ as presented in Table 2. The expected utility (EU) of option $A$ in row $i$ was formulated as (Andersen et al., 2008):

$E U_{A i}=p_{i} \cdot U\left(X_{A h}\right)+\left(1-p_{i}\right) \cdot U\left(X_{A l}\right)$

and option $B$

$E U_{B i}=p_{i} \cdot U\left(X_{B h}\right)+\left(1-p_{i}\right) \cdot U\left(X_{B l}\right)$

Following Holt and Laury (2002), we involve a noise parameter $(\mu)$ based on Luce's error (Luce, 1959). The $\mu$ allows randomness of choice. $P r_{i}^{H L}$ depicts the probability of choosing one of the two options ( $A$ or $B$ ) in row $i$ of the HL-task. Hence, the probability of choosing option $A$ can be formulated as (Holt and Laury, 2002) ${ }^{26}$ :

$\operatorname{Pr}_{i}^{H L}\left(A_{i}\right)=\frac{E U_{A_{i}}^{\frac{1}{\mu}}}{E U_{A_{i}}^{\frac{1}{\mu}}+E U_{B_{i}}^{\frac{1}{\mu}}}$

If $y$ is the decision in row $i$, then $y_{i}=A$ if the farmers chose option $A$. Similarly, $y_{i}=B$, if the farmers chose option $B$. The log-likelihood estimates the average of risk attitudes as farmers

\footnotetext{
${ }^{25}$ Andersen et al. (2008) added background consumption $(\omega)$ to define the utility but assumed $\omega$ is equal to zero. Therefore, in our estimation, we also assumed that $\omega$ is zero.

${ }^{26}$ The probability to choose option $B$ is similar to the equation (4).
} 
are treated as homogeneous (Liebenehm and Waibel, 2014). Moreover, this log-likelihood can also involve farmers' socioeconomic and demographic backgrounds. If the socioeconomic and demographic variables is denoted as $Z$, then the log-likelihood is (Andersen et al., 2008):

$$
\ln L^{H L}(\theta, \mu ; y, Z)=\sum_{i}\left(\left(\ln \left(P r_{i}^{H L}(A) \mid y_{i}=A\right)\right)+\left(\ln \left(1-P r_{i}^{H L}(A)\right) \mid y_{i}=B\right)\right)
$$

To estimate the discount rate, we denoted the payoffs of option $I$ as $M_{I}$, and $M_{I I}$ for the payoffs of option $I I$ in the $\mathrm{CW}$-task. Then, $t$ indicated the time of option $I$, which was $t=$ 7 days. The time for option $I I$ was $t+\tau$ ( $\tau$ is the time difference between options $I$ and $I I$ ). With the involvement of risk aversion coefficients, the present values $(P V)$ of the option $I$ and II in row $i$ of the CW-task were (Andersen et al., 2008):

$P V_{I_{i}}=\left(\frac{1}{1+\delta}\right)^{t} \cdot \frac{M_{I}^{1-\theta}}{1-\theta}$

and

$P V_{I I_{i}}=\left(\frac{1}{1+\delta}\right)^{t+\tau} \cdot \frac{M_{I I}^{1-\theta}}{1-\theta}$

Using $P r_{i}^{C W}$ we then depicted the probability of choosing one of the two options (I or $\left.I I\right)$ in row $i$ of the CW-task. Then, as we involved the noise parameter of the time preferences $(\vartheta)$, the probability of choosing option $I$ in row $i$ was formulated as (Andersen et al., 2008):

$P r_{i}^{C W}(I)=\frac{P V_{I_{i}}^{\frac{1}{\vartheta}}}{P V_{I_{i}}^{\frac{1}{\vartheta}}+P V_{I I_{i}}^{\frac{1}{\vartheta}}}$

If we used $w$ to indicate farmers' decision in row $i$, then $w_{i}=I$ if farmers chose option $I$ and $w_{i}=I I$ if they chose option II. Hence, if we involved socioeconomic and demographic variables $(Z)$ in the estimation, the log-likelihood was (Andersen et al., 2008):

$\ln L^{C W}(\delta, \theta, \mu, \vartheta ; w, Z)=\sum_{i}\left(\left(\ln \left(\operatorname{Pr}_{i}^{C W}(I) \mid w_{i}=I\right)+\left(\ln \left(1-\operatorname{Pr}_{i}^{C W}(I)\right) \mid w_{i}=I I\right)\right)\right.$

\section{Results and discussion}

After data checking and cleaning, 1,528 observations remain (772 Indian and 756 Indonesian farmers). Inconsistency (select option A, option B, and then option A again) could have 
occurred while conducting the HL- and CW-task that can lower the reliability of the measurement (Ihli et al., 2016). A possible way to reduce the inconsistency is to improve respondents' understanding. By usingcoloured pictures we were able to give the explanation and conduct one-by-one experiment (one farmer was accompanied by one fieldwork-assistant). In our dataset, the inconsistent answer in the HL-task is $7.67 \%$, while inconsistent answer in the CW-task is $1.59 \%$. In this article, we left-out the inconsistent answers from the calculation and present the results only from consistent answers.

\subsection{Comparison of farmers' preferences in India and Indonesia}

There are three classifications to interpret the estimated CRRA coefficient: (1) the value of $\theta$ is not statistically significantly different from zero, indicating risk-neutral; (2) the value of $\theta$ is negative and statistically significantly different from zero, indicating risk-loving; (3) the value of $\theta$ is positive and statistically significantly different from zero, indicating risk-averse decision makers on average. For the $\mathrm{CW}$-task, $\delta$ can be directly interpreted as the discount rate, for example a $\delta$ of 1.5 indicates a discount rate of $150 \%$ per year. Table 4 presents the estimation results of farmers' average risk attitudes and discount rate without controlling for the socioeconomics and demographic background in the estimation.

Table IV-4. Maximum likelihood estimation results of farmers' risk aversion and time preferences in India and Indonesia

\begin{tabular}{|c|c|c|c|c|c|}
\hline \multirow{2}{*}{ Countries and preferences ${ }^{a}$} & \multirow{2}{*}{ Coefficients } & \multirow{2}{*}{ Std. err. } & \multirow{2}{*}{$\mathrm{t}$-test ${ }^{b}$} & \multicolumn{2}{|c|}{$95 \%$ confidence interval } \\
\hline & & & & Lower & Upper \\
\hline \multicolumn{6}{|l|}{ India } \\
\hline Coefficient of risk attitudes $\theta$ & 0.17 & 0.02 & $* * *$ & 0.13 & 0.22 \\
\hline Discount rate $\delta$ & 1.90 & 0.14 & $* * *$ & 1.62 & 2.19 \\
\hline \multicolumn{6}{|l|}{ Indonesia } \\
\hline Coefficient of risk attitudes $\theta$ & 0.10 & 0.02 & $* * *$ & 0.07 & 0.13 \\
\hline Discount rate $\delta$ & 2.71 & 0.25 & $* * *$ & 2.22 & 3.20 \\
\hline
\end{tabular}

(Notes: ${ }^{a} \mathrm{~N}$ for Indian farmers $=15,440$ (number of clusters $=772$ ), $\mathrm{N}$ for Indonesian farmers $=15,120$ (number of clusters $=756 ;{ }^{b}$ Significance levels: $* * *$ at $1 \%, * *$ at $5 \%, *$ at $10 \%$. The significance levels indicate that the values are statistically significantly different from zero)

On average, the CRRA $(\theta)$ of the Indian farmers is 0.17 , while Indonesian farmers are at a level of 0.10 . The values of the risk attitude coefficients are positive and statistically significantly different from zero, this thereby indicated slightly risk-averse individuals on average based on the Holt and Laury classification (Holt and Laury, 2002 p. 10). To further examine whether the $\theta$ of the two groups are statistically significantly different, we carried out a t-test for two independent samples. The $\theta$ of both samples are statistically significantly 
different based on the t-test ( $\mathrm{p}$-value $=0.01$ ). This means that Indian farmers of our sample are more risk-averse than Indonesian farmers, on average.

Furthermore, the estimated $\delta$ of Indian farmers is 1.90, indicating an average discount rate of $190 \%$ in annual terms. The average discount rate of Indonesian farmers is $270 \%$ in annual terms. Similarly, we carried out the t-test to examine whether the two groups' discount rate is different. The t-test shows that the farmers' discount rate from both countries is statistically significantly different ( $\mathrm{p}$-value $=0.01$ ). This means that the discount rate of Indian farmers in our sample is lower than Indonesian farmers' discount rate, on average.

Compared to previous studies, the estimated discount rate in our study is relatively high. These numbers imply that the farmers want more than the double amount of payment than the current amount offered, if they must wait for one year. Utilising a laboratory experiment involving students in the United States of America (USA), Coller and Williams (1999) measure discount rate within the ranges of $17.5 \%-20 \%$ annually. Conducting a study in Germany, Hermann and Musshoff (2016) find annual discount rate within the interval of $7.3 \%-14.7 \%$ for students and $8.8 \%-12.9 \%$ for farmers, depending on the magnitude of baseline payoffs in the CW-task.

Nevertheless, India and Indonesia are much less developed than the USA and Germany, and the discount rate in developing countries are higher, as found in the literature (Holden et al., 1998; Poulos and Whittington, 2000). Involving the Indian sample, Atmadja et al. (2017) also encounter extremely high discount rate, i.e., 16.7\% monthly (if we convert the discount rate of Indian and Indonesian farmers in the monthly term, the discount rate is $16 \%$ and $23 \%$, respectively). Regarding possible methodological issues, we implemented two approaches that prevent overestimated discount rate. Firstly, we employed the joint-estimation-method where the risk aversion coefficient is involved in the discount rate estimation. This method has the benefit of preventing overestimated discount rate (e.g., Andersen et al., 2008; Sauter and Mußhoff, 2018). Secondly, the highest interest rate (upper border) used in the CW-task are not too high (100\%). Thus, the extremely high discount rate in our results is not a consequence of utilising too high upper border of the interest rate.

\subsection{Robustness check and possible influencing factors of the sociodemographics}

To check the robustness of these findings, we examine how the farmers' socioeconomic and demographic variables account for possible interaction with the risk attitudes and time preferences (cf. Liebenehm and Waibel, 2014). We use a dummy variable to indicate the country's effect. By pooling the observations from the two groups and creating a dummy 
variable named "country," where $1=$ India and $0=$ Indonesia, we estimate the coefficient of risk attitudes and discount rate using the joint-estimation-method. The results of the regression are presented in Table 5. Regarding risk attitude, the variable "country" has a positive value and is statistically significant at the $1 \%$ level. This confirms that the level of risk aversion is higher in India than in Indonesia, on average. Moreover, the variable "country" is statistically significant for the discount rate at the $1 \%$ level with a negative value. This implies that the discount rate is lower among Indian farmers. Accordingly, these findings confirm that our results are robust. Table 5 also shows farmers' socioeconomic information, which may have implications on the analysis of farmers' risk attitudes and discount rate.

Table IV-5. Maximum likelihood estimation results of farmers' risk attitudes and time preferences in India and Indonesia with socioeconomic and demographic characteristics

\begin{tabular}{|c|c|c|c|}
\hline Variables (units) $^{a}$ & Coefficients & Std. err. & $\mathrm{t}$-test ${ }^{b}$ \\
\hline \multicolumn{4}{|l|}{ Coefficient of risk attitudes } \\
\hline Country (= 1 if India) & $11.59 \times 10^{-2}$ & $2.87 \times 10^{-2}$ & $* * *$ \\
\hline Age (year-old) & $0.28 \times 10^{-2}$ & $0.10 \times 10^{-2}$ & $* *$ \\
\hline Education (years) & $-1.51 \times 10^{-2}$ & $0.31 \times 10^{-2}$ & $* * *$ \\
\hline Full-time farmer (= 1 if $\geq 50 \%$ income from farming) & $2.28 \times 10^{-2}$ & $3.26 \times 10^{-2}$ & ns \\
\hline Gender $(1=$ if male $)$ & $-2.47 \times 10^{-2}$ & $3.80 \times 10^{-2}$ & $\mathrm{~ns}$ \\
\hline Household size & $-0.39 \times 10^{-2}$ & $0.69 \times 10^{-2}$ & ns \\
\hline Loan formal (= 1 if has loan from formal institutions) & $-4.97 \times 10^{-2}$ & $2.42 \times 10^{-2}$ & $* *$ \\
\hline Loan informal ( 1 = if has loan from formal institutions) & $10.15 \times 10^{-2}$ & $7.97 \times 10^{-2}$ & ns \\
\hline \multicolumn{4}{|l|}{ Discount rate } \\
\hline Country (= 1 if India) & $-37.60 \times 10^{-2}$ & $11.39 \times 10^{-2}$ & $* * *$ \\
\hline Age (year-old) & $-0.56 \times 10^{-2}$ & $0.39 \times 10^{-2}$ & $\mathrm{~ns}$ \\
\hline Education (years) & $3.05 \times 10^{-2}$ & $1.20 \times 10^{-2}$ & $* *$ \\
\hline Full-time farmer (= 1 if $\geq 50 \%$ income from farming) & $17.55 \times 10^{-2}$ & $12.60 \times 10^{-2}$ & $\mathrm{~ns}$ \\
\hline Gender $(1=$ if male $)$ & $25.47 \times 10^{-2}$ & $13.46 \times 10^{-2}$ & $*$ \\
\hline Household size & $5.96 \times 10^{-2}$ & $2.59 \times 10^{-2}$ & $* *$ \\
\hline Loan formal (= 1 if has loan from formal institutions) & $14.25 \times 10^{-2}$ & $9.99 \times 10^{-2}$ & $\mathrm{~ns}$ \\
\hline Loan informal ( 1 = if has loan from formal institutions) & $16.13 \times 10^{-2}$ & $15.26 \times 10^{-2}$ & ns \\
\hline
\end{tabular}

(Notes: ${ }^{a} \mathrm{~N}$ for Indian farmers $=15,440$ (number of clusters $=772$ ), $\mathrm{N}$ for Indonesian farmers $=15,120$ (number of clusters $=756 ;{ }^{b}$ Significance levels: $* * *$ at $1 \%, * *$ at $5 \%, *$ at $10 \%, \mathrm{~ns}=$ non-significant $)$

The variables "age", "education", and "loan formal" are positive and statistically significantly correlated with risk attitude. The variable age is significant at $5 \%$ level with positive coefficient, yet the value of the coefficient is very close to zero. That is, the magnitude of the effect of farmers' age on the average risk attitude which becomes relatively small. As we move-on to the next significant variable, education, the magnitude of the effect is getting more pronounced. Farmers' education is associated with a lower level of risk aversion, on average. 
Indian farmers who have a shorter formal education ( 2 years, on average, cf. Table 1) show a higher level of risk aversion, on average. This finding is consistent with previous studies of Ihli et al. (2016) and Liebenehm and Waibel (2014). The third significant variable "loan formal" has a negative coefficient which inform us that having a loan from a formal institution decreases the average level of risk aversion. Indonesian farmers who engage more to loans from formal institutions show lower levels of risk aversion, on average. Thus, it seems that the loan from a formal institution helps the farmers to cope with risks.

Furthermore, regarding discount rate, the variables "education," "gender," and "household size" are positive and statistically significant. Our results show that on average the higher the formal education, the higher the discount rate. However, it does not mean that the policymaker should limit farmers' education to control discount rate at low level. Previous literature provides mixed conclusions on the effect of education on discount rate: (1) a higher level of education decreases the discount rate (Bauer and Chytilová, 2013); (2) there is no correlation between education and discount rate (Sauter and Mußhoff, 2018); (3) the discount rate remains low despite the diverse formal education (Harrison et al., 2002). Our study finds that male farmers have a higher discount rate than female farmers, on average, which is consistent with Bauer and Chytilová (2013) findings. Finally, we find a positive correlation between household size and discount rate, indicating that as household size increases, so does the discount rate. Studies mention that larger household size creates higher pressure on finances, and accordingly, the discount rate are also higher (e.g., Harrison et al., 2002; Liebenehm and Waibel, 2014; Tanaka et al., 2010).

\section{Conclusion}

This paper investigated and compared therisk attitudes and time preferences of farmers in two countries, India and Indonesia, where most participants lived in rural areas as full-time farmers. To investigates the preferences, we utilised two established elicitation methods: The Holt and Laury task to investigate risk attitudes and the Coller and Williams task to investigate the time preferences. We performed a joint-estimation-method based on Andersen et al. (2008).

The Indian farmers were more risk-averse, on average, yet the farmers in our sample showed very mild sign of risk aversion. The Indonesian farmers showed a higher level of discount rate than Indonesian farmers. The farmers' discount rate was extremely high while compared to the findings from previous studies. An extremely high discount rate depicted extensive impatience that potentially hinders farmers from participating in any long-term investment (Bauer and 
Chytilová., 2010), resulting in poverty-traps and incapability to maximise margins from farming activities. Nevertheless, many types of new technologies that support rural area development (e.g., contract farming, environmental conservation, sustainable agriculture) offer long-term benefits (Lee, 2005; Stevenson et al., 2014). The long-term benefits stretch beyond the short horizons of farmers' future planning, making them not appealing for farmers. To translate this into behaviour: farmers with a high discount rate may show low participation in specific agricultural programs.

The finding of this research should provide a preliminary insight for policymakers to make informed policies for future development projects and the adoption of technology in agriculture. The two countries are currently experiencing structural changes, in which farmers' risk attitude and time preference are important elements to predict farmers' investment or disinvestment. Thus, policymakers should put farmers' discount rate under consideration while implementing future policy or other development programs involving uncertain returns with long-term benefits (Harrison et al., 2005). For example, the farmers in the rural villages in India were surrounding a megacity and they interacted with urbanisation. Without financial support from governments or related parties, farmers with a high discount rate would likely prefer working in the city than staying in agriculture. This was because the agriculture sector only gave farmers income seasonally or annually. Furthermore, Indonesian farmers are currently experiencing the boom of oil palm production, in which the production is strongly related with degradation of environment (Grass et al., 2020; Wilcove and Koh, 2010). The idea of environmental preservation is an idealist thought which give comparatively far future benefit as it is a longterm program. As we found in our study, the farmers showed a high discount rate and without a sufficient financial incentive, they might put aside the idea of environmental preservation.

Regarding farmers' average risk attitudes, the variable "age", "education", and "loan formal" were statistically significant with positive coefficient. The magnitude effect of the variable age on lower level of risk aversion is marginal, while the magnitude effect of education and loan from formal institutions were more profound. On the average discount rate, the significant factors were education, gender, and household size. Confirming previous studies, we also found that male farmers and bigger sized households were related with the higher level of discount rate, on average.

Finally, it should be noted that the generalisation of the study results may have some limitations due to the diversity of culture and background within these two countries. India and Indonesia are remarkably diverse countries. However, the results can be useful primary 
information for the policymaker, focusing on rural area development involving smallholder farmers. Thus, future research can extend this study by conducting similar research in other developing countries in which the structural changes currently occur to expand the results' generalisability. It would also be of interest to extend this study by establishing a panel dataset of risk attitudes and time preferences in both countries. These panel data could be utilised to investigate whether risk attitudes and time preferences are changing over time. 


\section{References}

Anderhub V, Güth W, Gneezy U, Sonsino D. 2001. On the interaction of risk and time preferences: An experimental study. German Economic Review 2(3): 239-253. https://doi.org/10.1111/1468-0475.00036

Andersen S, Harrison GW, Lau MI, Rutström EE. 2008. Eliciting risk and time preference. Econometrica 76(3): 583-618. https://doi.org/10.1111/j.1468-0262.2008.00848.x

Atmadja SS, Sills EO, Pattanayak SK, Yang JC, Patil S. (2017). Explaining environmental health behaviors: evidence from rural India on the influence of discount rates. Environment and Development Economics 22(3), 229-248. https://doi.org/10.1017/S1355770X17000018

Barrett CB, Bachke ME, Bellemare MF, Michelson HC, Narayanan S, Walker TF. 2012. Smallholder participation in contract farming: comparative evidence from five countries. World Development 40(4): 715-730. https://doi.org/10.1016/j.worlddev.2011.09.006

Bauer M, Chytilová J. 2010. The impact of education on subjective discount rate in Ugandan villages. Economic Development and Cultural Change 58(4): 643-669. https://doi.org/10.1086/652475

Bauer M, Chytilová J. 2013. Women, Children and Patience: Experimental Evidence from Indian Villages. Review of Development Economics 17(4): 662-675. https://doi.org/10.1111/rode. 12057

Bauer M, Chytilová J, Morduch J. 2012. Behavioral foundations of microcredit: Experimental and survey evidence from rural India. American Economic Review 102(2): 1118-1139. https://doi.org/10.1257/aer.102.2.1118

Bharath HA, Chandan MC, Vinay S, Ramachandra TV. 2018. Modelling urban dynamics in rapidly urbanising Indian cities. The Egyptian Journal of Remote Sensing and Space Science 21(3): 201-210. https://doi.org/10.1016/j.ejrs.2017.08.002

Brick K, Visser M. (2015). Risk Preferences, Technology Adoption and Insurance Uptake: A Framed Experiment. Journal of Economic Behavior \& Organization 118:383-96. https://doi.org/10.1016/j.jebo.2015.02.010

Clough Y, Krishna VV, Corre MD, Darras K, Denmead LH, Meijide A, Moser S, Mußhoff O, Steinebach S, Veldkamp E, Allen K, Barnes AD, Breidenbach N, Brose U, Buchori D, Daniel R, Finkeldey R, Harahap I, Hertel D, Holtkamp AM, Hörandl E, Irawan B, Jaya INS, Jochum M, Klarner B, Knohl A, Kotowska MM, Krashevska V, Kreft H, Kurniawan S, Leuschner C, Marau M, Melati DN, Opfermann N, Pérez-Cruzado C, Prabowo WE, Rembold K, Rizali A, Rubiana R, Schneider D, Tjitrosoedirdjo SS, Tjoa A, Tscharntke T, Scheu. S. 2016. Land-use choices follow profitability at the expense of ecological functions in Indonesian smallholder landscapes. Nature Communications 7: 13137. https://doi.org/10.1038/ncomms13137

Coller M, Williams MB. 1999. Eliciting individual discount rates. Experimental Economics 2(2): 107-127. https://doi.org/10.1007/bf01673482

Fafchamps M. 2003. Rural poverty, risk and development. Edward Elgar Publishing Limited, United Kingdom.

Falk A, Becker A, Dohmen T, Enke B, Huffman D, Sunde U. 2018. Global evidence on economic preferences. The Quarterly Journal of Economics 133(4):1645-1692. https://doi.org/10.1093/qje/qjy013

Finnis E. 2006. Why grow cash crops? Subsistence Farming and Crop Commercialization in the Kolli Hills, South India. American Anthropologist. 108(2): 363-369. https://doi.org/10.1525/aa.2006.108.2.363 
Grass I, Kubitza C, Krishna VV, Corre MD, Mußhoff O, Pütz P, Drescher J, Rembold K, Ariyanti ES, Barnes AD, Brinkmann N, Brose U, Brümmer B, Buchori D, Daniel R, Darras KFA, Faust H, Fehrmann L, Hein J, Hennings N, Hidayat P, Hölscher D, Jochum M, Knohl A, Kotowska MM, Krashevska V, Kreft H, Leuschner C, Lobite NJS, Panjaitan R, Polle A, Potapov AM, Purnama E, Qaim M, Röll A, Scheu S, Schneider D, Tjoa A, Tscharntke T, Veldkamp E, Wollni M. 2020. Trade-offs between multifunctionality and profit in tropical smallholder landscapes. Nature Communications. 11(1):1-3. https://doi.org/10.1038/s41467-020-15013-5

Harrison GW, Humphrey SJ, Verschoor A. 2009. Choice under uncertainty: evidence from Ethiopia, India and Uganda. The Economic Journal 120(543): 80-104. https://doi.org/10.1111/j.1468-0297.2009.02303.x

Harrison GW, Lau MI, Rutström EE, Sullivan MB. 2005. Eliciting risk and time preferences using field experiments: Some methodological issues. Field experiments in economics 10: 125-218. https://doi.org/10.1016/s0193-2306(04)10005-7

Hermann, D., Musshoff, O. 2016. Measuring time preferences: Comparing methods and evaluating the magnitude effect. Journal of Behavioral and Experimental Economics 65:16-26. https://doi.org/10.1016/j.socec.2016.09.003

Hertwig R, Ortmann A. 2001. Experimental practices in economics: A methodological challenge for psychologists? Behavioral and Brain Sciences 24: 383-451.

Hoffmann EM, Jose M, Nölke N, Möckel T. 2017. Construction and use of a simple index of urbanisation in the rural-urban interface of Bangalore, India. Sustainability 9(11): 2146. https://doi.org/10.3390/su9112146

Holt CA, Laury SK. 2002. Risk aversion and incentive effects. American Economic Review 92(5): 1644-1655. https://doi.org/10.1257/000282802762024700

Holden ST, Shiferaw B, Wik M. 1998. Poverty, market imperfections and time preferences: of relevance for environmental policy? Environment and Development Economics 3(1): 105-130. https://doi.org/10.1017/s1355770x98000060.

Ihli HJ, Chiputwa B, Musshoff O. 2016. Do changing probabilities or payoffs in lottery-choice experiments affect risk preference outcomes? Evidence from rural Uganda. Journal of Agricultural and Resource Economics 41: 324-345.

Jin J, Wang W, Wang X. 2016. Farmers' risk preferences and agricultural weather index insurance uptake in rural China. International Journal of Disaster Risk Science 7(4): 366373. https://doi.org/10.1007/s13753-016-0108-3

Knight J, Weir S, Woldehanna T. 2003. The role of education in facilitating risk-taking and innovation in agriculture. The Journal of Development Studies 39(6): 1-22. https://doi.org/10.1080/00220380312331293567

Laury SK, McInnes MM, Swarthout JT. 2012. Avoiding the curves: Direct elicitation of time preferences. Journal of Risk and Uncertainty 44(3): 181-217. https://doi.org/10.1007/s11166-012-9144-6

Lee, D. R. 2005. Agricultural sustainability and technology adoption: Issues and policies for developing countries. American journal of agricultural economics 87(5): 1325-1334. https://doi.org/10.1111/j.1467-8276.2005.00826.x

Liebenehm S, Waibel H. 2014. Simultaneous estimation of risk and time preferences among small-scale cattle farmers in West Africa. American Journal of Agricultural Economics 96(5): 1420-1438. https://doi.org/10.1093/ajae/aau056

Luce, R.D. 1959. Individual choice behavior: A theoretical analysis. Wiley, United States of America.

Patil VS, Thomas BK, Lele S, Eswar M, Srinivasan V. 2019. Adapting or chasing water? Crop choice and farmers' responses to water stress in peri-urban Bangalore, India. Irrigation and Drainage 68(2):140-51. https://doi.org/10.1002/ird.2291. 
Park A, Wang S. 2010. Community-based development and poverty alleviation: an evaluation of China's poor village investment program. Journal of Public Economics 94(9-10): 790799. https://doi.org/10.1016/j.jpubeco.2010.06.005

Poulos C, Whittington D. 2000. Time preferences for life-saving programs: evidence from six less developed countries. Environ. Sci. Technol. 34(8): 1445-1455. https://doi.org/10.1021/es990730a

McIntosh C, Sarris A, Papadopoulos F. 2013. Productivity, credit, risk, and the demand for weather index insurance in smallholder agriculture in Ethiopia. Agricultural Economics 44(4-5): 399-417. https://doi.org/10.1111/agec.12024

Nguyen Q. 2011. Does nurture matter: Theory and experimental investigation on the effect of working environment on risk and time preferences. Journal of Risk and Uncertainty 43(3): 245-270. https://doi.org/10.1007/s11166-011-9130-4

Ngwira AR, Thierfelder C, Eash N, Lambert DM. 2013. Risk and maize-based cropping systems for smallholder Malawi farmers using conservation agriculture technologies. Experimental Agriculture 49(4): 483-503. https://doi.org/10.1017/s0014479713000306

Ortiz-Ferrara G, Joshi AK, Chand R, Bhatta MR, Mudwari A, Thapa DB, Suwan MA, Saikia TP, Chatrath R, Witcombe JR, Virk DS, Sharma RC. 2007. Partnering with farmers to accelerate adoption of new technologies in South Asia to improve wheat productivity. Euphytica 157(3): 399-407. https://doi.org/10.1007/s10681-007-9353-2

Ramachandra TV, Bharath AH, Sowmyashree MV. 2015. Monitoring urbanization and its implications in a mega city from space: Spatiotemporal patterns and its indicators. Journal of environmental management 148: 67-81. https://doi.org/10.1016/j.jenvman.2014.02.015.

Sauter PA, Mußhoff O. 2018. What is your discount rate? Experimental evidence of foresters' risk and time preferences. Annals of Forest Science 75(1): 10. https://doi.org/10.1007/s13595-017-0683-5

Stevenson JR, Serraj R, Cassman KG. 2014. Evaluating conservation agriculture for small-scale farmers in Sub-Saharan Africa and South Asia. Agriculture, Ecosystem and Environment 187: 1-10. https://doi.org/10.1016/j.agee.2014.01.018

Tanaka T, Camerer CF, Nguyen Q. 2010. Risk and time preferences: Linking experimental and household survey data from Vietnam. American Economic Review 100(1): 557-71. https://doi.org/10.1257/aer.100.1.557

Wang M, Rieger MO, Hens T. 2016. How time preferences differ: Evidence from 53 countries. Journal of Economic Psychology 52: 115-135. https://doi.org/10.1016/j.joep.2015.12.001

Wegmann J, Mußhoff O. 2019. Groundwater management institutions in the face of rapid urbanization-Results of a framed field experiment in Bengaluru, India. Ecological Economics 166. https://doi.org/10.1016/j.ecolecon.2019.106432

Wilcove DS, Koh LP. 2010. Addressing the threats to biodiversity from oil-palm agriculture. Biodiversity and Conservation 19(4): 999-1007. https://doi.org/10.1007/s10531-0099760-x

World Bank. (2017). GDP per capita. Accessed on 12.04.2019. Available at: https://data.worldbank.org/indicator/

World Bank. (2018). Population. Accessed on 30.04.2018. Available at: https://data.worldbank.org/indicator/

Zhu J, Simarmata HA. 2015. Formal land rights versus informal land rights: Governance for sustainable urbanization in the Jakarta metropolitan region, Indonesia. Land Use Policy 43: 63-73. https://doi.org/10.1016/j.landusepol.2014.10.016 


\section{General conclusions: findings, outlooks, and policy recommendations}

\section{Paper-1}

In developing countries, the technology adoption in agriculture meets harder challenges due to poverty, limit access to information, and shortcomings in agricultural insurance. The challenges are aggravated by risk aversion and high discount rates. These circumstances hold farmers in a poverty-trap within the cycle: reluctant to adopt - being left out from innovations' benefits stay poor (Brick and Visser, 2015). Agricultural insurances can break this cycle, but they are not well established or unaffordable for farmers (Carter et al., 2017). These issues are potentially problematic as farmers receive the market's pressure to produce sustainable food due to environmental issues. This creates tension for them to immediately adopt sustainable farming practices, especially when they produce a crop that receives global attention for environmental issues, such as oil palm.

Market-based schemes for sustainable palm oil production is palm oil certification. In Indonesia, the two most common palm oil certifications are RSPO and ISPO. Many years after the certification implementation, farmers' participation remains low. We observe that only $4.25 \%$ of farmers in our sample knew or ever heard about the certifications. The effect of certification on the environment are obtained only if more farmers participate because farmers manage the biggest area of oil palm plantations (around 60\%; Grass et al., 2020).

Paper-1 investigates three policy scenarios to support farmers' participation in certifications. Those are price premium (additional 50\%), providing environmental information (land-use change in Jambi), and communication of group norm (revealing the group members). We used an ex-ante policy impact analysis to evaluate the policies' effects in advance. To do so, we conducted a field experiment that involved farmers and observed their decisions regarding deforestation before and after the policies' implementation. Following the negative framing design by Andreoni (1995), farmers were blindly and randomly grouped (four farmers per group). They were confronted with two choices: (1) conduct deforestation and make extra income, yet reduce income of other farmers in his/her group; (2) conserve forest and not receive extra income but potentially get income reduction from other farmers' deforestation. 
We find that price premiums and information about land-use change in Jambi successfully encourage farmers to conserve forests. However, to date, the price premium is not well-regulated and gives room for traders or mill companies to determine the price premium freely. For example, Hidayat et al. (2015) mention the price premium of 5\%, but Von-Geibler (2013) mentions the price premium of $8-15 \%$. Another problem is the insufficiency of the price premium to cover the extra cost for producing certified oil palm fruits (Hidayat et al., 2015). Hence, policymakers and related agencies should evaluate the current price premium. Chavas and Nauges (2020) mention that information about innovations' benefits has important roles for adoption. Thus, the policymaker and certification agencies should consider emphasizing these benefits and provide sufficient information to farmers. Besides, this study suggests that non-monetary benefits such as the information of land-use change can be one alternative to increase farmers' awareness about environmental issues and support their participation.

Future research can extend Paper-1 by investigating the price premium at different magnitudes. Furthermore, as our study focused on discouraging deforestation, future research can extend the discussion by examining further Principles and Criteria $(\mathrm{P} \& \mathrm{C})$ of palm oil certification, for example, good waste management or environmentally friendly pest control. Finally, future research can discuss the trade-offs between social and environmental issues or trade-offs between social and farmers' welfare.

\section{Paper-2}

While the participation in the certifications occurred slowly, the diffusion of oil palm happened smoothly and rapidly despite the importance of rubber in Jambi. Paper-2 investigates farmers' decision to cultivate two perennial crops and find that risk-aversion reasons the diversification. Hence, despite the reluctance of cultivating a new crop, the urge to diversify crops is stronger among risk-averse farmers.

These results provide a preliminary insight for policymakers to either encourage or discourage crop-diversifications. If the policymakers encourage crop-diversification (support oil palm adoption), then establishing more mills/factories is necessary because oil palm fruits must be processed within two days. The government can provide training about allocating inputs and managing two crops efficiently. In contrast, when the government focuses on rubber production, then imposing floor prices or providing agricultural insurances during the rainy season are necessary. In addition, a rubber price policy should be enforced and evaluated, as apparently, the price is asymmetrically transmitted and creates a loss for farmers (Kopp et al., 2017). 
Nevertheless, to promote or not to promote monoculture is a challenging topic due to environmental issues. The monoculture relates to deforestation, biodiversity degradation and transformation of environmentally friendly farming practice, i.e., agroforest (Gatto et al., 2015). Therefore, environmental sustainability should be considered if the government plan to further promote oil palm and rubber monoculture. Future research can conduct in-depth interviews to investigate the decision of crop-diversification. Besides, future research can extend the observations by involving farmers who switch entirely to oil palms. In this way, one can compare the risk attitudes and time preferences from three groups of farmers: cultivate one crop, two crops, and change crop.

\section{Paper-3}

The third paper investigates risk attitudes and time preferences involving farmers from India and Indonesia, involving 1,528 farmers. The involvement of the two countries were basd on several consideration, those are: (1) both countries are currently experiencing the structural changes, where farmers are slowly leaving the subsistence farming and producing cash crops (e.g., Finnis, 2006; Grass et al., 2020), (2) interm of population, India and Indonesia belong to the top four countries in the world, where the population growth are very high (37\% for India and $32 \%$ for Indonesia) and the poverty among small-scale farmers are still major (World Bank, 2018), (3) both countries are currently deal with the rapid urbanisation, which potentially problematic regarding the poverty in the city and decreasing young generations in farming (Patil et al., 2019). By comparing the preferences, we could make a comparison whether the farmers preferences from two comparable countries are the same.

From this study, we found that the Indian farmers are more patient than Indonesian farmers. Yet, the Indian farmers are significantly more risk-averse. To check the robustness of the finding, we pooled the observation and created a dummy variable named "country," where country $=1$ if India and country $=0$ if otherwise. In this estimation, farmers' socioeconomics and demographic backgrounds are included. Regarding the discount rate, the variable "country" is negative and statistically significant at $1 \%$ level. Regarding risk attitude, the variable "country" is positive and statistically significant at $1 \%$ level. These results confirm our previous calculation: Indian farmers in our sample are more risk-averse and have lower discount rates than Indonesian farmers. Hence, our results are robust.

This estimation also observed some veraiable of farmers' background which have implications on the analysis of farmers' risk attitudes and discount rate. Regarding the risk 
attitude, the variable "age" is positive and statistically significant, indicating that older farmers are more risk-averse than younger farmers. Variable "education" and "loan formal" are negative and statistically significant. These indicate that higher education and having a loan from a formal institution relate to lower risk aversion. Regarding the discount rates, the variable "education" is positive and statistically significant, indicating that farmers with higher education show higher discount rates. However, it does not mean that the policymakers should reduce farmers' education to promote lower discount rates but to provide attention to the extremely high discount rates. Previous literature also found mixed relation between education and farmers' discount rates: (1) higher education relates to lower discount rates (Bauer and Chytilová, 2013); (2) there is no relation between education and discount rates (Sauter and Mußhoff, 2018). We also find that the variables "gender" and "household size" are positive and statistically significant, indicating that male farmers and bigger size of household (more members / more children) correlated with higher discount rates.

Future research on this topic is still necessary. For instance, Kollmuss and Agyeman (2002) introduce "temporal discrepancy," stating that individuals' attitude changes over time. Future research can extend this study by creating a panel dataset of farmers' risk attitudes and time preferences in India and Indonesia. Using this panel dataset, one can examine whether the farmers' attitudes are changing over time. 


\section{References}

Andreoni, J. 1995. Warm-Glow Versus Cold-Prickle: The effects of positive and negative framing on cooperation in experiment. The Quarterly Journal of Economics 110(1): 121. https://doi.org/10.2307/2118508

Bauer M, Chytilová J. 2013. Women, Children and Patience: Experimental Evidence from Indian Villages. Review of Development Economics 17(4): 662-675. https://doi.org/10.1111/rode.12057.

Brick K, Visser M. 2015. Risk preferences, technology adoption and insurance uptake: A framed experiment. Journal of Economic Behavior \& Organization 118:383-96. https://doi.org/10.1016/j.jebo.2015.02.010

Carter M, de Janvry A, Sadoulet E, Sarris A. 2017. Index insurance for developing country agriculture: a reassessment. Annual Review of Resource Economics 5(9):421-38. https://doi.org/10.1146/annurev-resource-100516-053352

Chavas JP, Nauges C. 2020. Uncertainty, Learning, and Technology Adoption in Agriculture. Applied Economic Perspectives and Policy 42(1): 42-53. https://doi.org/10.1002/aepp.13003

Gatto M, Wollni M, Qaim M. 2015. Oil palm boom and land-use dynamics in Indonesia: The role of policies and socioeconomic factors. Land Use Policy 46: 292-303. https://doi.org/10.1016/j.landusepol.2015.03.001

Finnis E. 2006. Why grow cash crops? Subsistence Farming and Crop Commercialization in the Kolli Hills, South India. American Anthropologist. 108(2): 363-369. https://doi.org/10.1525/aa.2006.108.2.363

Grass I, Kubitza C, Krishna VV, Corre MD, Mußhoff O, Pütz P, Drescher J, Rembold K, Ariyanti ES, Barnes AD, Brinkmann N, Brose U, Brümmer B, Buchori D, Daniel R, Darras KFA, Faust H, Fehrmann L, Hein J, Hennings N, Hidayat P, Hölscher D, Jochum M, Knohl A, Kotowska MM, Krashevska V, Kreft H, Leuschner C, Lobite NJS, Panjaitan R, Polle A, Potapov AM, Purnama E, Qaim M, Röll A, Scheu S, Schneider D, Tjoa A, Tscharntke T, Veldkamp E, Wollni M. 2020. Trade-offs between multifunctionality and profit in tropical smallholder landscapes. Nature Communications. 11(1):1-3. https://doi.org/10.1038/s41467-020-15013-5

Hidayat NK, Glasbergen P, Offermans A. 2015. Sustainability certification and palm oil smallholders' livelihood: A comparison between scheme smallholders and independent smallholders in Indonesia. International Food and Agribusiness Management Review 18(3): 25-48.

Kollmuss A, Agyeman J. 2002. Mind the gap: why do people act environmentally and what are the barriers to pro-environmental behavior?. Environmental education research, 8(3): 239-260. https://doi.org/10.1080/13504620220145401

Kopp T, Brümmer B, Alamsyah Z, Fatricia RS. 2017. Welfare implications of intertemporal marketing margin manipulation. British Food Journal 119(8): 1656-1671. https://doi.org/10.1108/BFJ-11-2016-0572

Patil VS, Thomas BK, Lele S, Eswar M, Srinivasan V. 2019. Adapting or chasing water? Crop choice and farmers' responses to water stress in peri-urban Bangalore, India. Irrigation and Drainage 68(2):140-51. https://doi.org/10.1002/ird.2291.

Sauter PA, Mußhoff O. 2018. What is your discount rate? Experimental evidence of foresters' risk and time preferences. Annals of Forest Science 75(1): 10. https://doi.org/10.1007/s13595-017-0683-5 
Von-Geibler, J. 2013. Market-based governance for sustainability in value chains: Conditions for successful standard setting in the palm oil sector. Journal of Cleaner Production 56: 39-53. https://doi.org/10.1016/i.jclepro.2012.08.027

World Bank. (2018). Population. Accessed on 30.04.2018. Available at: https://data.worldbank.org/indicator/ 


\section{LIST OF PUBLICATIONS}

\section{Publications}

Sarwosri AW, Mußhoff O. 2020. Risk and time preferences of farmers in India and Indonesia. EFForTS Discussion Paper No. 32.

Sarwosri AW, Mußhoff O. 2020. Are risk attitudes and time preferences crucial factors for crop-diversification by smallholder farmers? Journal of International Development.

Sarwosri AW, Wegmann J, Mußhoff O. 2020. Discouraging rainforest transformation: an exante policy impact analysis. Journal of Agricultural Economics 71(1): 219-238.

Sarwosri AW, Mußhoff O. 2019. Can crop-diversification of perennial crop by smallholder farmers explained by risk attitudes and time preferences? EFForTS Discussion Paper No. 28.

Sarwosri AW, Wegmann J, Mußhoff O. 2018. Encouraging rainforest preservation by smallholders: an ex-ante policy evaluation. EFForTS Discussion Paper No. 23.

Sarwosri AW, Roemer U, Mußhoff O. 2016. Are African female farmers disadvantages on the microfinance lending market? Agricultural Finance Review 46(4): 477-493.

\section{Conferences}

Sarwosri AW, Mußhoff O. Risk attitudes and discount rate: crucial factors for planting oil palms by smallholders? AARES Annual Conference Melbourne, Australia, February 12-15, 2019.

Sarwosri AW, Mußhoff O. Socio-ecological transformations of tropical lowland rainforests CRC-990: EFForTS Symposium, Bali, Indonesia, October 07-11, 2018.

Sarwosri AW, Wegmann J, Mußhoff O. Encouraging the acceptance of ISPO and RSPO certification for Indonesian small-size farmers. International Association of Agricultural Economist, Talca, Chile, October 17-20, 2017.

Sarwosri AW, Roemer U, Mußhoff O. Are African female farmers disadvantaged on the microfinance lending market? $8^{\text {th }}$ China Agricultural Economic Review (CAER) and International Food Policy Research Institute (IFPRI) Annual Conference, Fuzhou, China October 23-25, 2016. 


\section{DECLARATION OF CONTRIBUTION}

Paper-1 (Chapter II) - Discouraging rainforest transformation: an ex-ante policy impact analysis. This paper was written with following authors: Johannes Wegmann and Oliver Mußhoff. My contribution as the leading author was to develop idea, create design of the experiment, conduct fieldwork, and prepare dataset. Johannes Wegmann as the second author provided important supports during the construction of econometric model, econometric analysis, and writing. I also benefited from the discussion to create design of the experiment, comments and writing suggestions Oliver Mußhoff. Dian Melati contributed by providing the land-use map of Jambi Province for the experiment.

Paper-2 (Chapter III) - Are risk attitudes and time preferences crucial factors for cropdiversification by smallholder farmers? This paper was written with following author: Oliver Mußhoff. My contribution as the leading author was to develop idea, conduct fieldwork, and prepare dataset. The second author, Oliver Mußhoff provided substantial discussion, comments, and suggestions during writing. Rakhma Melati Sujarwo contributed by providing secondary dataset of rubber and oil palm price. Christoph Kubitza provided information of GPS coordinates for the research villages and became the creator of Jambi Province map that was presented in the Paper-2. I also benefited from Daniel Hermann and Vannesa Bonke for internal review before submission to the publisher.

Paper-3 (Chapter IV) - Risk attitudes and time preferences of farmers in two comparable Asian countries: study in India and Indonesia. This paper was written with following author: Oliver Mußhoff. My contribution as the leading author was to develop idea as well as conducted fieldwork and prepared dataset for Indonesian farmers. The second author, Oliver Mußhoff provided substantial discussion, comments, and suggestions during writing. Johannes Wegmann provided dataset of Indian farmers' HL-task and CW-task. I also benefited from Johannes Wegmann, Selina Bruns and Ulf Roemer for internal review before submission to the publisher.

I also received support for English proof-reading from multiple parties and due to the limitation of German language ability, I received support from Tobias Kracht for the German translation of the summary (Zusammenfassung). 


\section{STATUTORY DECLARATION}

\section{Declaration according to $\$ 12$ section 1 c) + Appendix 2 of the Doctoral degree regulations}

for the Graduate School of Forest and Agricultural Sciences (GFA) at University of Göttingen

I confirm that I have composed the present scientific treatise (thesis) independently using no other sources of resources than those stated. I have accepted the assistance of third parties only in a scope that is scientifically justifiable and compliant with the legal statutes of the examinations. I have completed all parts of the dissertation myself; I have neither, nor will I, accept unauthorized outside assistance either free of charge or subject to fee.

Furthermore, I have not applied for an equivalent doctoral examination elsewhere and submitted the present thesis as a whole or in parts at another university. I am aware of the fact that untruthfulness with respect to the above declaration repeals the admission to complete the doctoral studies and/or subsequently entitles termination of the doctoral process or withdrawal of the title attained.

Göttingen, $7^{\text {th }}$ December 2020

Signature of the applicant Arieska Wening Sarwosri 